\title{
TRANSFORMAÇÃO GENÉTICA DE MARACUJÁ AMARELO VISANDO RESISTÊNCIA À Xanthomonas axonopodis pv. passiflorae
}

MARIZA MONTEIRO

Tese apresentada à Escola Superior de Agricultura "Luiz de Queiroz", Universidade de São Paulo, para obtenção do título de Doutor em Agronomia, Área de concentração: Genética e Melhoramento de Plantas.

PIR A C I C A B A

Estado de São Paulo - Brasil

Fevereiro - 2005 


\title{
TRANSFORMAÇÃO GENÉTICA DE MARACUJÁ AMARELO VISANDO RESISTÊNCIA À Xanthomonas axonopodis pv. passiflorae
}

\author{
MARIZA MONTEIRO \\ Bióloga
}

Orientadora: Profa. Dra. MARIA LUCIA CARNEIRO VIEIRA

Tese apresentada à Escola Superior de Agricultura "Luiz de Queiroz", Universidade de São Paulo, para obtenção do título de Doutor em Agronomia, Área de concentração: Genética e Melhoramento de Plantas.

PIR A C I C A B A

Estado de São Paulo - Brasil

Fevereiro - 2005 
Dados Internacionais de Catalogação na Publicação (CIP) DIVISÃO DE BIBLIOTECA E DOCUMENTAÇÃO - ESALQ/USP

Monteiro, Mariza

Transformação genética de maracujá amarelo visando resistência à Xanthomonas axonopodis pv. passiflorae / Mariza Monteiro. - - Piracicaba, 2005.

134 p. : il.

Tese (doutorado) - - Escola Superior de Agricultura Luiz de Queiroz, 2005. Bibliografia.

1. Agrobacterium 2. Bacteriose vegetal 3. Maracujá 4. Proteína de planta 5. Transformação genética 6 . Xanthomonas I. Título

CDD 634.425 
"Não é a instrução que nos faz encontrar CRISTO, mas a pureza do coração"

Aos meus pais Miriam e Waldomiro,

pelo amor, carinho e incentivo constante

e a quem devo tudo que sou

\section{OFEREÇO}

Ao Marcus, pelo amor, paciência, carinho e incentivo

DEDICO 


\section{AGRADECIMENTOS}

Agradeço a todas as pessoas que, de forma direta ou indireta, contribuíram para a realização deste trabalho, especialmente:

À Escola Superior de Agricultura "Luiz de Queiroz" (ESALQ), em particular ao Departamento de Genética, pela possibilidade de realizar o Doutorado;

À Coordenadoria de Aperfeiçoamento de Pessoal de Nível Superior (CAPES), pela concessão da bolsa de estudos;

À Profa. Dra. Maria Lúcia Carneiro Vieira, pela orientação, paciência, apoio e estímulos constantes para a realização do presente trabalho;

À Dra. Sabrina Moutinho Chabregas (Centro de Tecnologia Canavieira Copersucar), pela amizade, co-orientação e apoio nos ensaios de direcionamento e análise transcricional;

À Profa. Dra. Beatriz Appezzato-da-Glória (Departamento de Ciências Biológicas - ESALQ), pela orientação nas análises histológicas e auxílio na documentação fotográfica;

Ao Prof. Jorge A. M. Rezende (Departamento de Fitopatologia - ESALQ), pela orientação no bioensaio;

Aos Chefes de laboratórios que permitiram a utilização de equipamentos e outras facilidades: Dr. Marcio de Castro Silva-Filho, Dra. Margarida L. R. de Aguiar-Perecin e Dra. Aline Aparecida Pizzirani-Kleiner;

À Dra. Maria Imaculada Zucchi, pela ajuda na utilização do programa de alinhamento BCM Search Launcher.

À doutoranda Juliana A. Fernando, pela ajuda nas análises de microscopia de varredura dos materiais de maracujá. 
À doutoranda Maria Carolina Quecine, pela ajuda na utilização do software SAS;

Aos técnicos de laboratório Carlos Alberto de Oliveira e Marli Soares, pela amizade e excelente e valioso auxílio durante a execução da parte experimental;

Aos amigos Joelma, Scheila, Américo, Bete, Silvana, Juliano, Eder, Luciane, Frederico, Michel, Francisco, Luiz Ricardo, Renato, Adriano e Viviane por todos estes anos de convívio, apoio e amizade inestimáveis;

Aos colegas do Laboratório de Genética de Microrganismos e do Laboratório de Biologia Molecular, pelo apoio e amizade inestimáveis;

Aos meus pais, Waldomiro e Miriam, à minha irmã Tomiris, ao meu cunhado Abrahão, aos meus sobrinhos Gabriela e Gustavo e ao meu marido Marcus, pelo amor, paciência, compreensão e incentivos constantes.

Aos funcionários do Departamento de Genética;

Aos meus colegas do Programa de Pós-graduação em Agronomia (Genética e Melhoramento de Plantas);

E a DEUS, por tudo. 


\section{SUMÁRIO}

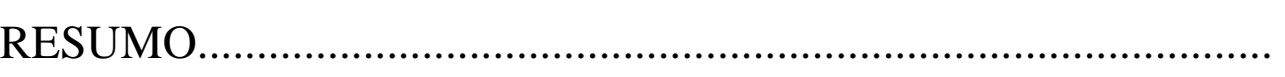

Página

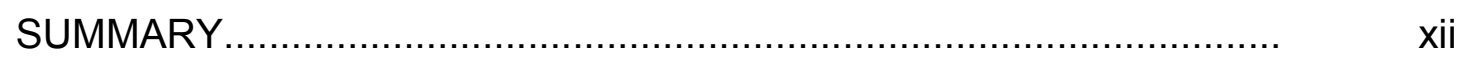

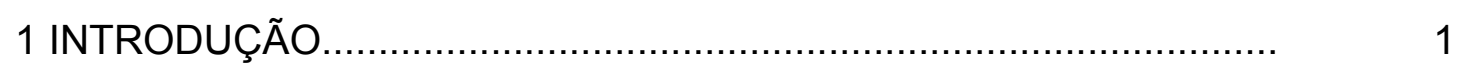

2 REVISÃO DE LITERATURA...........................................................

2.1 A cultura do maracujá e suas principais doenças .............................

2.2 Uso de métodos biotecnológicos para assistir ao melhoramento genético do maracujá...............................................................

2.2.1 Transformação genética visando resistência a patógenos: considerações gerais..

2.2.2 Cultura de tecidos como pré-requisito para transformação genética, com ênfase em Passiflora............................................ 13

2.3 Eletroporação de protoplastos.......................................................... 18

2.4 Transformação por Agrobacterium tumefaciens.............................. 20

2.5 Marcadores seletivos em transformação de plantas......................... 23

2.6 Estratégias para obtenção de resistência à bacteriose através da

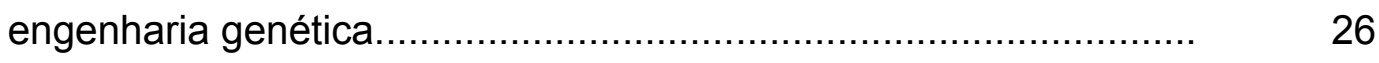

2.6.1 Transformação de plantas com o gene da atacina......................... $\quad 29$

2.7 Localização subcelular das proteínas............................................ 
3 MATERIAL E MÉTODOS ........................................................... 35

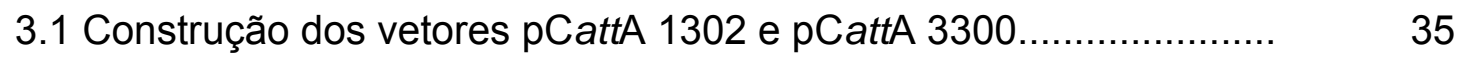

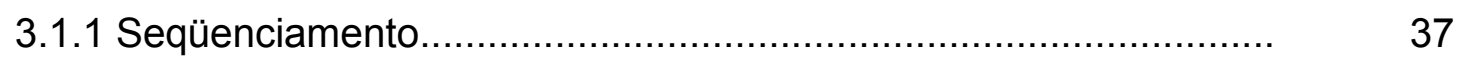

3.2 Direcionamento da proteína atacina A.................................... 38

3.2.1 Construção dos vetores pSPattA 1303 e pattA 1303................... 38

3.2.2 Transformação por biobalística das células da epiderme de cebola

3.3 Cultura in vitro

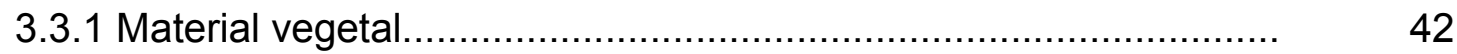

3.3.2 Germinação in vitro de sementes de maracujá amarelo................ 43

3.3.3 Eletroporação de protoplastos

3.3.3.1 Isolamento, cultura e regeneraçãp de protoplastos de maracujá amarelo

3.3.3.2 Otimização da concentração de higromicina e fosfinotricina para seleção dos transformantes

3.3.3.3 Otimização das condições de eletroporação de protoplastos.....

3.4 Transformação de maracujá amarelo por Agrobacterium tumefaciens

3.4.1 Transformação das linhagens desarmadas de A. tumefaciens......

3.4.2 Cultura de explantes.

3.4.3 Infecção de explantes de maracujá amarelo por $A$. tumefaciens...

3.4.5 Ensaio histoquímico e localização anatômica da expressão do gene uidA. 
3.4.6 Regeneração de plantas a partir de explantes de maracujá amarelo infectados com $A$. tumefaciens.

3.4.7 Análise molecular dos transformantes

3.4.7.1 Via reação em cadeia da polimerase (PCR)

3.4.7.2 Análise dos transcritos de att A por RT-PCR.

3.5.1 Resistência à Xanthomonas axonopodis pv. passiflorae

3.5.2 Resistência ao herbicida Finale ${ }^{\circledR}$

4 RESULTADOS E DISCUSSÃO

4.1 Construção dos vetores pCattA 1302 e pCattA 3300.

4.2 Direcionamento da proteína atacina A.

4.2.1 Construção dos vetores pSPattA 1303 e pattA 1303

4.2.2 Transformação por biobalística das células da epiderme de cebola.

4.3.1 Germinação in vitro de sementes de maracujá amarelo.

4.3.2 Eletroporação de protoplastos.

4.3.2.1 Isolamento, cultura e regeneração de protoplastos de maracujá amarelo.

4.3.2.2 Otimização da concentração de higromocina e fosfinotricina para seleção dos transformantes.

4.3.2.3 Otimização das condições de eletroporação de protoplastos.....

4.4 Transformação de maracujá amarelo por Agrobacterium tumefaciens. 
4.4.1 Transformação das linhagens desarmadas de A. tumefaciens......

4.4.2 Cultura de explantes.

4.4.3 Infecção de explantes de maracujá amarelo por Agrobacterium tumefaciens 88

4.4.4 Análise ultra-estrutural das microfibrilas de celulose

4.4.5 Ensaio histoquímico e localização anatômica da expressão do gene uidA...

4.4.6 Regeneração de plantas a partir de explantes de maracujá amarelo infectados com $A$. tumefaciens.

4.4.7 Análise molecular dos transformantes.

4.4.7.1 Via reação em cadeia da polimerase (PCR)

4.4.7.2 Análise dos transcritos de att A por RT-PCR.

4.5 Bioensaios.

4.5.1 Resistência à Xanthomonas axonopodis pv. passiflorae.

4.5.2 Resistência ao herbicida Finale ${ }^{\circledR}$ 99

4.6 Resumo dos resultados, biossegurança e perspectivas. 100 5 CONCLUSÕES. 104 REFERÊNCIAS 


\section{TRANSFORMAÇÃO GENÉTICA DE MARACUJÁ AMARELO VISANDO RESISTÊNCIA À Xanthomonas axonopodis pv. passiflorae}

Autora: MARIZA MONTEIRO

Orientadora: Profa. Dra. MARIA LUCIA CARNEIRO VIEIRA

\section{RESUMO}

A bacteriose, ou mancha oleosa, doença causada por Xanthomonas axonopodis pv. passiflorae, é um sério problema em muitas áreas de produção de maracujá no Brasil, especialmente se associada à antracnose. A transformação genética é uma alternativa para obter plantas resistentes. Proteínas bactericidas, como as atacinas encontradas na hemolinfa de insetos, têm sido usadas para conferir resistência a espécies vegetais. Como as atacinas têm um peptídeo sinal que as direciona para o espaço extracelular em insetos, nós iniciamos este estudo investigando o direcionamento da atacina $A$ em plantas. A seqüência do gene da atacina $A(a t t A)$ com e sem o peptídeo sinal foi fusionada com os genes repórteres uidA e gfp e epidermes de cebola foram transformadas, via biobalística, com essas construções gênicas. A atacina $A$, de fato, é acumulada no apoplasto onde, justamente, bactérias fitopatogênicas se multiplicam antes de invadir as células vegetais. Visando obter plantas transgênicas resistentes à bacteriose, foram transformados tecidos foliares e hipocotiledonares com as linhagens LBA 4404 e EHA 105 de Agrobacterium tumefaciens contendo o gene attA. De um total de 313 explantes infectados, foram obtidos 31 brotos PCR+, o que representa uma eficiência de 
transformação da ordem de $10 \%$. A expressão do transgene foi confirmada por RT-PCR e a resistência ao patógeno foi avaliada pela inoculação de X. axonopodis pv. passiflorae em folhas destacadas de plantas mantidas in vitro. Em dez plantas não houve formação de lesão foliar, indicando uma possível resistência ao patógeno. 


\title{
GENETIC TRANSFORMATION OF YELLOW PASSION FRUIT TO CONFER RESISTANCE TO Xanthomonas axonopodis pv. passiflorae
}

\author{
Author: MARIZA MONTEIRO \\ Adviser: Dr. MARIA LUCIA CARNEIRO VIEIRA
}

\section{SUMMARY}

Bacterial spot disease caused by Xanthomonas axonopodis pv. passiflorae is a serious problem in many passion fruit production areas in Brazil, especially if associated with anthracnose. Genetic transformation provides an alternative for obtaining resistant plants. Bactericide proteins such as attacins, found in the haemolymph of insects, have been used to confer resistance on plant species. As the attacins have a sign peptide that dispatches them to extracellular space in insects, we initiated our studies investigating the attacin $A$ directing in plants. The attacin A gene (attA) sequence, with and without the sign peptide, was fused to uidA and gfp reporter genes, and onion epidermis were transformed using bioballistics with gene constructions. The protein did accumulate in the apoplast, where bacteria multiply before attacking plant cells. With the aim of obtaining transgenic plants of yellow passion fruit resistant to bacterial disease, leaf and hypocotyl-derived tissues were transformed with LBA 4404 and EHA 105 strains of Agrobacterium tumefaciens containing the attA gene. From a total of 313 infected explants, we obtained 31 PCR+ shoots, a transformation efficiency of $10 \%$. Expression of the attA gene was confirmed by RT-PCR, and pathogen resistance evaluated by $X$. axonopodis pv. passiflorae 
inoculation in leaves obtained from in vitro plants. Leaf lesions were not observed in 10 shoots, suggesting a possible resistance to pathogen. 


\section{IINTRODUÇÃO}

O Brasil é o maior produtor mundial de maracujá: tem cerca de 33.040 ha de área plantada e responde por uma produção de 467.464 t/ano (FNP Consultoria e Agroinformativos, 2004). A espécie mais utilizada nos plantios comerciais brasileiros é Passiflora edulis f. flavicarpa, o maracujá amarelo, própria para consumo in natura e à industrialização de suco.

Do ponto de vista fitossanitário, há duas doenças principais que atacam os pomares de maracujá: uma virose severa, causada pelo vírus do endurecimento do fruto ou PWV (da sigla inglesa, Passion fruit Woodiness Virus) e a bacteriose provocada por Xanthomonas axonopodis pv. passiflorae.

A bacteriose, ou mancha oleosa, se caracteriza pelo aparecimento de pequenas lesões nas folhas mais internas da planta, com aspecto oleoso, translúcido e um halo amarelado. Em condições de ataque severo, as folhas secam e caem, há grande desfolha em cultivos e conseqüente redução drástica da frutificação, podendo causar a morte da planta. Há registros de que o controle químico é ineficiente, mas tratos culturais podem diminuir a incidência da doença, como o uso de quebra-ventos (eucaliptal, por exemplo) circundando o plantio.

Considerando o prejuízo que essas doenças tem causado aos produtores e à indústria, a busca por cultivares resistentes (ou tolerantes) tornase imprescindível. Projetos de pesquisa na área de melhoramento têm sido conduzidos em instituições públicas e privadas brasileiras visando à obtenção de variedades mais produtivas e resistentes. No entanto, os resultados são 
ainda modestos e, além disso, não há fonte de resistência (ou tolerância) à $X$. axonopodis pv. passiflorae bem caracterizada na espécie comercial.

Métodos de biotecnologia vegetal têm sido indicados para complementar certos programas de melhoramento: no caso específico do maracujazeiro, a transgenia se apresenta como um caminho viável para a obtenção de cultivares resistentes.

O uso de genes de insetos, que expressam proteínas com atividade bactericida, tem sido proposto para a produção de plantas transgênicas resistentes a doenças. Insetos possuem um sistema imune que é baseado em polipeptídios com função antibacteriana como, por exemplo, as atacinas encontradas em mariposas (Hyalophora cecropia e Trichoplusia ni). Esta família de proteínas age em bactérias Gram-negativas como Escherichia, Acinetobacter, Pseudomonas, Erwinia e Xanthomonas. O gene atacina E (att E) foi usado para produzir plantas transgênicas de pêra (Reynord et al., 1999) e maçã (Ko et al., 2000), as quais se mostraram resistentes à Erwinia amylovora.

Devido à carência de um método químico ou biológico de controle eficaz contra a bacteriose do maracujazeiro (i), à severidade da doença (ii), e à importância econômica da cultura (iii), é de grande interesse obter plantas de maracujá resistentes à bacteriose pela expressão de genes com função antibacteriana, como, por exemplo, os da família das atacinas. O gene da atacina $A$ foi clonado por um grupo sueco (Kang et al, 1996) e cedido ao Departamento de Genética da ESALQ/USP através do IAPAR (Londrina, PR). A construção do cassete de expressão foi realizada por Takahashi et al. (2001), e usado para a transformação genética de Citrus, via Agrobacterium tumefaciens (Boscariol et al., 2004) e do maracujazeiro (Castro et al., 2004), via biobalística.

A hipótese na qual se fundamenta este trabalho é que a expressão da proteína heteróloga atacina $\mathrm{A}$ deve levar à produção de plantas de maracujá resistentes. Sendo assim, esta tese teve como meta produzir plantas transgênicas resistentes à bacteriose. Como objetivos específicos, adequar os protocolos de transformação genética via eletroporação de protoplastos e 
mediada por $A$. tumefaciens e, também, comprovar o direcionamento da proteína atacina A para o meio extracelular, em plantas.

Questões de biossegurança relativas ao sistema proposto nesta tese para o controle da bacteriose são discutidas. 


\section{REVISÃO DE LITERATURA}

\subsection{A cultura do maracujá e suas principais doenças}

A família Passifloraceae, a qual pertence o maracujá, é constituída por 18 gêneros e cerca de 630 espécies distribuídas, principalmente, na América Tropical, Ásia e África. Desses gêneros, destaca-se Passiflora, com cerca de 150 espécies originárias do Brasil, que é o principal centro de diversidade genética (Vanderplanck, 1996).

Apesar desse grande número de espécies, somente algumas são comercialmente importantes em função de suas propriedades medicinais ou da qualidade de seus frutos para consumo. As principais espécies que produzem frutos comestíveis são: Passiflora edulis f. flavicarpa (maracujá amarelo) e $P$. edulis (maracujá roxo), P. ligularis (granadilla), P. molissima (maracujá-curuba), P. quadrangularis (maracujá-açu), P. maliformis, P. caerulea (maracujá de cobra), $P$. laurifolia (maracujá-laranja) e $P$. alata (maracujá doce).

Brasil, Colômbia, Peru, Equador, África do Sul, Austrália, Sri Lanka, Nova Guiné, Hawai e Taiwan são os países que respondem por $85 \%$ da produção mundial de maracujás, embora nem todos cultivem a mesma espécie (Menzel et al., 1988). Na Austrália e na Índia, o maracujá-roxo é o preferido, enquanto no Havaí predomina o amarelo. Já no Brasil, as espécies utilizadas comercialmente para consumo in natura ou para produção de suco, são o amarelo, o roxo e o doce (Souza \& Meletti, 1997).

O Brasil é o primeiro produtor mundial de maracujá (Ruggiero, 2000). A produção está distribuída entre as regiões Norte $(7,4 \%)$, Nordeste $(53,5 \%)$, 
Sudeste $(31,7 \%)$, Centro-Oeste $(4,4 \%)$ e Sul $(3,0 \%)$. O Estado de São Paulo é o terceiro maior produtor $(15,1 \%)$, responsável por cerca de 70.800 t/ano (FNP Consultoria \& Agroinformativos, 2004).

Nas últimas décadas, a área cultivada com maracujá aumentou consideravelmente no País, sem que os cuidados técnicos necessários (uso de tratos culturais adequados e variedades melhoradas) fossem devidamente observados. Tal comportamento tem propiciado o aumento dos problemas fitossanitários a ponto de reduzir a exploração econômica da cultura e, até mesmo, inviabilizar o cultivo em determinadas regiões. Observa-se que os pomares de maracujá têm sido afetados por doenças causadas por fungos, bactérias e vírus, as quais exigem dedicação e esforços urgentes, no sentido de minimizar as perdas e evitar, sobretudo, a sua disseminação (Santos Filho et al., 2004).

Das doenças que atacam os maracujazeiros, duas merecem destaque: a virose causada pelo Passion fruit Woodiness Virus (PWV) e a bacteriose provocada por Xanthomonas axonopodis pv. passiflorae.

A virose é uma doença que ocorre na parte aérea e nos frutos, caracterizada pelo endurecimento do fruto acompanhado, em alguns casos, de enrugamento, deformações e bolhas no limbo foliar, reduzindo a produção quantitativa e qualitativamente (Rezende \& Kitagima, 2003).

A transmissão natural do PWV em campo se dá por meio de afídeos, principalmente, pulgões. Nos dias de hoje, o PWV ocorre na maioria dos pomares e não há relatos de resistência genética ou formas eficazes de controle. A premunização das plantas com estirpes fracas do vírus também tem sido motivo de investigações, porém os resultados não são promissores (Novaes \& Rezende, 2001).

A bacteriose, ou mancha oleosa, é uma das doenças mais severas, mormente se associada à antracnose, que tem limitado a expansão dos pomares de maracujá (Barbosa, 1995; Souza e Melleti; 1997). Ocorre, preferencialmente, em condições de alta temperatura $\left(35^{\circ} \mathrm{C}\right)$ e umidade e em 
plantas com distúrbios nutricionais. É caracterizada pelo aparecimento de pequenas lesões nas folhas, com aspecto oleoso, translúcido e um halo amarelado. Posteriormente, adquirem coloração marrom, forma irregular, aspecto deprimido na face inferior da folha, podendo coalescer e atingir todo $o$ limbo foliar. Em condições de ataque severo da bactéria, as folhas secam e caem, e há grande desfolha. Verifica-se, também, que a infecção se inicia pelos bordos foliares e caminha pelas nervuras, que adquirem uma coloração avermelhada, atingindo o pecíolo. É uma doença sistêmica e a infecção pode avançar através dos feixes vasculares dos pecíolos e ramos, provocando caneluras longitudinais e seca desses órgãos a partir de suas extremidades, o que reduz drasticamente a frutificação, podendo causar a morte da planta. Nos frutos, ocorre o aparecimento de pequenas lesões de aspecto aquoso e de coloração verde escura que ao evoluírem adquirem aparência oleosa e coloração parda. Estas lesões podem atingir a polpa dos frutos, inviabilizando a comercialização (Pio-Ribeiro \& Mariano, 1997; Dias, 2000).

Diversas medidas têm sido recomendadas para o controle preventivo da bacteriose, como a produção de mudas sadias, poda de limpeza, uso de quebra-ventos, e aplicação de produtos bactericidas (Teixeira, 1994). No entanto, o controle não é eficaz; é uma prática bastante onerosa ao produtor e prejudicial ao meio ambiente (Embrapa - Reunião Técnica, 1998).

Considerando-se que essas duas doenças levam à redução da produtividade do maracujazeiro e da área de plantio, e a perdas por parte do setor produtivo, é de fundamental importância que sejam realizadas pesquisas visando o seu controle. 


\subsection{Uso de métodos biotecnológicos para assistir ao melhoramento genético do maracujá}

Métodos de biotecnologia vegetal têm sido indicados para complementar certos programas de melhoramento genético. A biotecnologia vegetal é uma extensão do melhoramento convencional de plantas. Ela pode ser considerada como uma nova maneira de fazer, de forma mais precisa, uma atividade que o homem iniciou há, aproximadamente, 10 mil anos - selecionar tipos com características superiores (Borém et al., 1998).

A aplicação de métodos de biotecnologia no melhoramento de espécies frutíferas tem sido crescente e com amplas possibilidades de sucesso. As contribuições mais importantes vieram da hibridação somática, pela fusão de protoplastos, técnica aplicada para a produção de porta-enxertos comerciais em Citrus, e da transformação genética mediada por Agrobacterium ou baseada na introdução de DNA exógeno mediante a eletroporação de protoplastos ou tecidos integros, polietilenoglicol (PEG) ou aceleração de partículas (Otoni, 1995).

A hibridação somática no gênero Passiflora, via fusão de protoplastos, representa uma alternativa de transferência de genes de espécies selvagens para a espécie cultivada (Vieira, 1997), contornando os problemas de incompatibilidade, as barreiras de cruzamento e de fertilidade observadas no processo convencional de obtenção de híbridos sexuais. Contudo, a introgressão de genes por essa tecnologia é limitada devido a diversos fatores, mormente pela natureza poliplóide dos híbridos somáticos, o que conduz a meioses irregulares, e à dificuldade de se conduzir os retrocruzamentos subseqüentes com o genitor cultivado. Híbridos somáticos entre $P$. edulis $\mathrm{f}$. flavicarpa e as espécies silvestres, $P$. alata, $P$. cincinnata e $P$. giberti foram obtidos por Dornelas et al. (1995) com o objetivo de produzir porta-enxertos resistentes a doenças de solo. Otoni et al. (1995a) regeneraram plantas 
híbridas de $P$. edulis flavicarpa $+P$. incarnata, mediante eletrofusão de protoplastos.

A transformação de plantas, através da engenharia genética, vem sendo utilizada para um grande número de espécies. Genes derivados de espécies vegetais não relacionadas e até de outros reinos (bactérias, fungos e animais), que eram considerados inacessíveis para o melhorista, podem, com essa nova tecnologia, ser introduzidos em variedades elites obtidas por melhoramento convencional.

Proteínas ou peptídeos exógenos podem ser expressos em plantas transgênicas e assim introduzir novas fontes de resistência ou complementar mecanismos já existentes (During, 1996). Os avanços dessa técnica e o entendimento da interação patógeno hospedeiro facilitaram a criação de plantas resistentes a doenças via transgenia (Mourgues et al., 1998).

No caso específico dos maracujazeiros, a transformação de plantas se constitui em uma alternativa de transferência de genes de resistência a doenças. O primeiro trabalho de transformação de maracujá amarelo foi realizado por Manders et al. (1994), utilizando Agrobacterium tumefaciens, visando à introdução do gene que confere resistência ao antibiótico canamicina (nptll); em seguida, vieram os trabalhos de Otoni et al. (1996a), via biobalística, Silva (1998) e Hall et al. (2000), via A. tumefaciens, que relataram a introdução e a expressão do gene repórter uidA. A introdução de um gene de importância agronômica foi realizada por Braz (1999) visando obter plantas de maracujá resistentes ao vírus do endurecimento do fruto. Não há registro, no entanto, de que esse trabalho tenha produzido plantas expressando a proteína viral exógena e, portanto, resistentes ao vírus. 


\subsubsection{Transformação genética visando resistência a patógenos: considerações gerais}

A engenharia genética dispõe de várias estratégias para a produção de plantas resistentes a patógenos. Por exemplo, para resistência a vírus, são utilizados genes que expressam proteínas virais, sendo os mais usados os genes da capa protéica. Há várias espécies transformadas com este fim, como o tabaco com resistência ao ToMoV (Tomato Mottle Virus) (Sinisterra et al., 1999) e o mamão resistente ao Papaya Ringspot Virus - biotipo P (PRSV-P) (Fitch et al., 1992). A presença dessas proteínas na célula hospedeira interrompe a transcrição, replicação ou mesmo a disseminação do vírus (SilvaFilho \& Falco, 2001). Outras abordagens usadas para a obtenção de plantas resistentes a vírus são:

i) pela expressão da replicase viral, como feito em tabaco para obter resistência ao CMV (Cucumber Mosaic Virus) (Hellwald et al., 1995);

ii) pela expressão de proteínas envolvidas no movimento do vírus na planta, tal como realizado em tabaco para obter resistência ao TMV (Tobacco Mosaic Virus) (Lapidot et al., 1993);

iii) uso de RNA anti-senso ("antisense RNA") que é complementar a uma das fitas do genoma viral, como feito em tabaco para induzir resistência ao TGMV (Tomato Golden Mosaic Virus) (Bejarano \& Lichtenstein, 1994);

iv) uso de RNA satélite, que tem a propriedade de reduzir a replicação do vírus e atenuar o sintoma produzido, como realizado em tomate para obter resistência ao CMV (Cucumber Mosaic Virus) (McGarvey \& Kaper, 1993);

v) uso de RNA defectivo interferente, estratégia freqüentemente associada a uma diminuição dos sintomas da doença viral, 
como feito em Nicotiana benthamiana para obter resistência ao BCTV (Beet Curly Top Geminivirus) (Stenger, 1994).

Maior detalhamento sobre as diferentes estratégias relacionadas à obtenção de plantas resistentes a vírus pode ser obtido nas revisões publicadas por Hadidi et al. (1998), Cooper (1999) e Romano \& Monte (1999).

Quanto à obtenção de plantas transgênicas resistentes a doenças bacterianas, as estratégias aplicadas envolvem, mormente, a introdução de genes que codificam proteínas bactericidas. Estes genes têm sido isolados a partir de artrópodes, anfíbios e mamíferos (ver revisão de Mourgues et al., 1998). As proteínas bactericidas usadas para induzir resistência a patógenos, em plantas, incluem os peptídeos líticos isolados a partir de insetos, como as cecropinas e análogos (Jaynes et al., 1993; Huang et al., 1997), as atacinas (Norelli \& Aldwinckle, 1993; Norelli et al., 1994; Chen \& Kuehnle, 1996; Boscariol, 2004), as lisozimas (During et al., 1993) e outros peptídeos antibacterianos, como a lactoferrina (Mitra \& Zhang et al., 1994). Maior detalhe sobre a utilização e modo de ação das proteínas bactericidas, especificamente das atacinas, será relatado adiante.

Outra estratégia para obter resistência a bactérias, via transgenia, baseia-se na inibição da patogenicidade bacteriana ou de seus fatores de virulência, como a inibição da toxina produzida por Pseudomonas syringae pv. tabaci, pela expressão do gene ttr (tabtoxina resistente) relatada em tabaco por Anzai et al. (1989).

A exploração das defesas naturais das plantas também tem sido usada e baseia-se na (i) produção de elicitores (Wegener et al., 1996), (ii) introdução de genes de origem vegetal, tal como feito em arroz para obter resistência à Xanthomonas oryza pv. oryza, onde foi inserido o gene Xa21, isolado de um cultivar resistente (Wang et al., 1996) ou (iii) superexpressão de genes de defesa através da produção de fitoalexinas, como as tioninas (Carmona et al., 1993). 
A morte celular programada artificialmente para a região de infecção é outra estratégia utilizada para obter resistência a doenças causadas por bactérias e compreende o uso de promotores induzidos pela presença do patógeno (De Wit, 1992; Strittmatter et al., 1995; Mittler et al., 1995).

Genes que codificam alguma proteína letal, como o gene $B t$, têm sido usados para o controle a nematóides; inibidores de proteinases, do tipo cisteínas, foram utilizados para obter resistência a Globodera pallida em tabaco (Urwin et al., 1995). Outra alternativa é usar genes fitotóxicos, que bloqueiam o desenvolvimento das células alimentadoras dos nematóides, dirigidos por promotores altamente tecido-específicos (Silva-Filho \& Falco, 2001).

Plantas transgênicas resistentes a fungos têm sido geradas pela introdução de genes que codificam proteínas antifúngicas, como as tioninas, cuja atividade antimicrobiana baseia-se na capacidade em gerar poros na membrana celular do patógeno, resultando em sua lise e, conseqüentemente, em sua morte. Epple et al. (1997) observaram que a expressão da tionina em plantas transgênicas de Arabidopsis thaliana resultaram no aumento da resistência a Fusarium oxysporum. Outros peptídeos antifúngicos têm sido estudados e seu uso potencial está relatado em Grover \& Gowthaman (2003).

A primeira planta transgênica comercialmente produzida foi o tomate "Flavr Savr", em 1996, modificado para reduzir os níveis de enzima poligalacturonase, aumentando o seu "tempo de prateleira". Desde então, registra-se uma massiva expansão de culturas transgênicas no campo, particularmente, milho, soja, canola e algodão (para revisão, veja Dunwell, 2000).

A grande maioria das plantas transgênicas comerciais teve como alvo imediato o produtor agrícola. Os caracteres mais freqüentemente incorporados têm sido aqueles que reduzem o custo da produção de um cultivar transgênico, como a resistência a herbicidas. O exemplo mais divulgado (e comercializado em vários países) é a soja contendo o transgene de resistência ao glifosato, 
princípio ativo do herbicida Roundup, produzida pela empresa Monsanto (Azevedo et al., 2000; Quecini \& Vieira, 2001).

Outra característica comumente incorporada é a resistência a pragas, e os genes mais utilizados comercialmente são os isolados de Bacillus thuringiensis $(B t)$ que produzem endotoxinas (ver revisão de Frutos et al., 1999). Existe um grande número de plantas transgênicas resistentes a insetos obtidas pela transferência de genes $B t$, dentre elas o tomate (Fischoff et al., 1987), o algodão (Perlak et al., 1990), o tabaco (Willians et al., 1993), o milho (Koziel et al., 1993), a soja e a canola (Stewart et al., 1996). Atualmente, genes que codificam peptídeos que atuam como inibidores de proteinases (IPs) também têm sido propostos para induzir resistência a insetos em plantas transgênicas (Silva-Filho \& Falco, 2001).

A área global cultivada com plantas transgênicas é de 67.7 milhões de hectares, sendo que os principais países produtores são os Estados Unidos, com 42,8 milhões de hectares; a Argentina, com 13,9; o Canadá, com 4,4; o Brasil, com 3,0; a China, com 2,8 e a África do Sul que cultiva 0,4 milhões de hectares de transgênicos (http://www.isaaa.org).

As principais culturas transgênicas comercializadas são:

i) a soja tolerante à herbicida (41,4 milhões de hectares), representando $55 \%$ da área de soja cultivada;

ii) o milho resistente a insetos, contendo o gene $B t$, e tolerante à herbicida (15,5 milhões de hectares), representando $11 \%$ da área cultivada com milho;

iii) algodão resistente a insetos $(B t)$ e tolerante à herbicida $(7,2$ milhões de hectares), representando $21 \%$ da área cultivada com algodão;

iv) canola tolerante à herbicida (3,6 milhões de hectares) representando $16 \%$ da área cultivada com canola;

v) Outras culturas, como abóbora e o mamão, que representam menos de 0,1 milhão de hectares cultivados. 


\subsubsection{Cultura de tecidos como pré-requisito para transformação genética, com ênfase em Passiflora}

Atualmente, as técnicas de transformação estão bem estabelecidas para um grande número de espécies (Halford, 2004). No entanto, o pré-requisito básico para o sucesso dessa tecnologia i.é, a transferência de genes em plantas, é o desenvolvimento de protocolos eficientes de regeneração de brotos (Silva-Filho \& Falco, 2001).

Segundo Birch (1997), no processo de cultura in vitro usado na transformação, o mais importante é o número de células regeneráveis acessíveis ao sistema de transformação. Também, uma alta taxa de formação de brotos não necessariamente indica um grande número de células regeneráveis acessíveis à transformação (Livingstone et al., 1995), pois a transferência de DNA pode ocorrer em células que não possuam capacidade de regeneração (Ross et al., 1995).

Existem várias métodos de introdução de DNA em células hospedeiras, sendo dois os mais utilizados a transformação mediada pelo Agrobacterium tumefaciens e a biobalística. Em ambos, para se ter sucesso, é importante realizar análises histológicas para determinar à priori, a localização e os tipos celulares que dão origem aos meristemóides no explante (Matsumoto et al., 1996), e avaliar se estas células estarão acessíveis à transformação. Por exemplo, quando se usa $A$. tumefaciens como vetor de transformação, as células que possuam potencial de regeneração devem estar localizadas na superfície do explante, acessíveis às bactérias (Vieira \& Appezzato-da-Glória, 2001).

Vários protocolos eficientes de regeneração têm sido desenvolvidos para um grande número de espécies importantes (Aragão, 2002), porém para Hibiscus sabdariffa (Gassama-Dia et al., 2004), espécies de eucaliptos 
(González, 2002), dentre várias outras, a cultura de tecidos tem sido um fator limitante para obtenção de plantas transgênicas.

A principal via de regeneração para diversas espécies de Passiflora tem sido relatada como a organogênica, dentre elas $P$. edulis, $P$. edulis f. flavicarpa, P. molissima, P. giberti, P. amethystina e P. caerulea (Moran Nobles, 1978; 1979; Dornelas \& Vieira, 1994; Appezato-da-Glória et al., 1999; Biasi et al., 2000; Monteiro et al., 2000a; Reis, 2001; Becerra et al., 2004). A formação de novo (ou adventícia) vem sendo obtida a partir de diversos tipos de explantes, como segmento nodal e internodal (Kantharajah \& Dodd, 1990; Biasi et al., 2000; Reis, 2001), discos foliares (Otahola, 2000; Monteiro et al., 2000a; Becerra et al., 2004), segmentos cotiledonares (Dornelas \& Vieira, 1994; Hall et al., 2000) e hipocotiledonares (Fernando et al., 2004) e a partir da cultura de protoplastos (D'Utra Vaz et al., 1993; Dornelas \& Vieira, 1993; Dornelas et al., 1995; Otoni et al., 1995a, 1995b, 1996b).

Dornelas \& Vieira (1994) foram pioneiros ao descrever um protocolo para proliferação de ápices caulinares e regeneração de plantas via organogênese direta a partir de explantes de $P$. edulis f. flavicarpa, $P$. molissima, $P$. giberti, $P$. maliformis e $P$. amethystina.

Há consenso na literatura que a morfogênese in vitro pode ser influenciada por diversos fatores (e pelas suas interações), tais como: a) fonte, tamanho e idade do explante; $b$ ) condição fisiológica do órgão doador; $c$ ) condição ambiental na qual a planta doadora é mantida; $d$ ) genótipo da planta (Vasil \& Thorpe, 1994). Com base nisto, Dornelas \& Vieira (1994) avaliaram os efeitos da origem dos explantes, das concentrações de fitorreguladores e da água de coco, e da radiação luminosa na resposta morfogênica de $P$. edulis $\mathrm{f}$. flavicarpa. Os autores utilizaram hipocótilos, cotilédones e discos foliares cultivados em meio MS (Murashige \& Skoog, 1962) contendo várias combinações de ácido naftalenoacético (ANA) $(0,0 ; 1,0$ e 2,0 mg/L), 6benzilaminopurina (BA) $(0,0 ; 0,5 ; 1,0$ e 2,0 mg/L) e de água de coco $(0,0 ; 5,0$; 10,0 e $20,0 \%$ ). Os resultados mostraram que MS acrescido de $2,0 \mathrm{mg} / \mathrm{L}$ de BA 
e $10 \%$ de água de coco foi ideal para promover a organogênese e que os explantes cotiledonares foram os mais responsivos. Biasi et al. (2000) analisaram a resposta morfogênica em segmentos internodais de maracujá amarelo cultivados em meio contendo 1,0 a $4,0 \mathrm{mg} / \mathrm{L}$ de BA. Os autores observaram que as concentrações de 1,0 e 2,0 mg/L foram as mais adequadas para induzir à formação de brotos.

O efeito das condições fisiológicas e da idade da planta doadora de explante foi estudado por Becerra et al. (2004) utilizando explantes foliares de maracujá amarelo com um a seis meses de idade. Plantas jovens (1 a 2 meses) induziram de forma mais eficiente à formação de brotos.

Dornelas \& Vieira (1994) relataram que a adição de água de coco ao meio causa um aumento na proliferação celular em explantes de maracujá amarelo. Isto já havia sido observado por Mourad-Agha \& Dexheimer, (1979) em P. quadrangularis. Kantharajah \& Dodd (1990) e Hall et al. (2000) observaram maior formação de gemas adventícias em $P$. edulis e em híbridos de $P$. edulis $\times P$. edulis var. flavicarpa com a adição de água de coco ao meio de regeneração. Entretanto, Passos (1999) relatou que a organogênese direta a partir de discos foliares de $P$. nitida ocorre em meio contendo 0,5 ou $1,0 \mathrm{mg} / \mathrm{L}$ de BA, na ausência de água de coco.

Appezzato-da-Glória et al. (1999) realizaram estudos anatômicos em discos foliares de maracujá amarelo cultivados com BA e ANA e na presença ou ausência de luz. Houve a formação de centros meristemáticos, após 14 dias, e de gemas adventícias nos explantes tratados com BA, na presença e ausência de luz, porém, nesta última condição, em menor freqüência. Os explantes cultivados com ANA apresentaram desenvolvimento de meristemas radiculares quando cultivados no escuro. Neste trabalho, os autores confirmaram que as gemas caulinares formaram-se nas camadas subepidérmicas na lâmina foliar.

Tecidos hipocotiledonares dessa mesma espécie, cultivados em meio de regeneração ( $\mathrm{MS}+1,0 \mathrm{mg} / \mathrm{L} \mathrm{BA}+5,0 \%$ água de $\mathrm{coco}$ ), foram analisados 
anatomicamente e observou-se que a formação dos meristemóides ocorreu, também, nas camadas superficiais do explante (Juliana A. Fernando, comunicação pessoal ${ }^{1}$ ) (Figura 1).

Com base nesses relatos, conclui-se que a técnica de transformação genética via Agrobacterium é bastante favorável para o maracujá amarelo, pois os meristemóides são formados superficialmente, ou seja, em regiões acessíveis à infecção bacteriana.

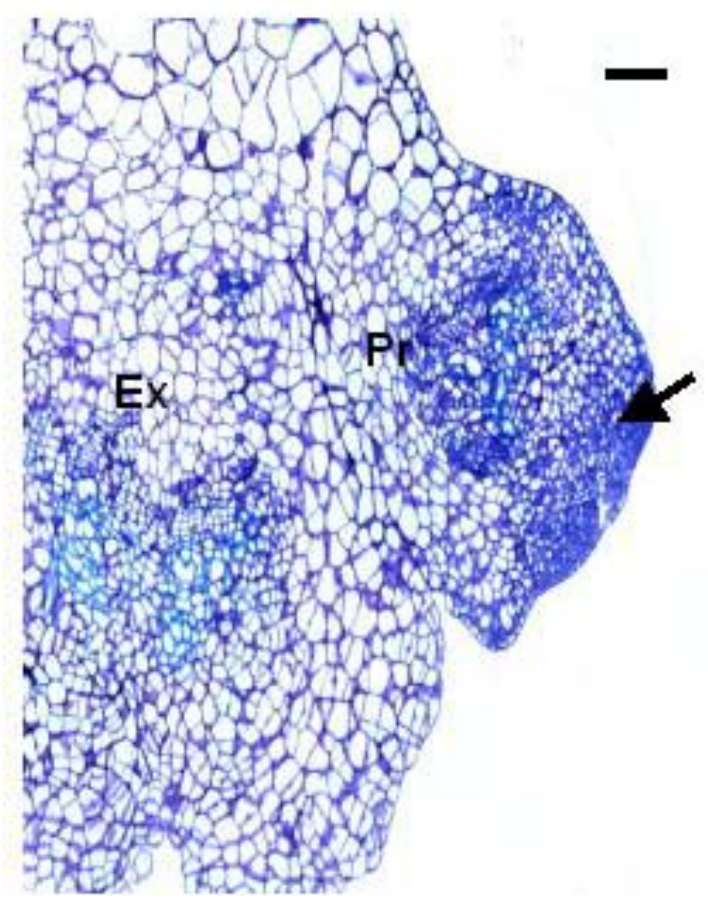

Figura 1 - Áreas meristemáticas (setas) formadas na periferia da protuberância $(\mathrm{Pr})$ originada diretamente no explante hipocotiledonar (Ex) (Barra = $100 \mu \mathrm{m})$

Fonte: Foto cedida pela bióloga Juliana Aparecida Fernando, do trabalho de tese de doutoramento, com defesa prevista para maio de 2005, no Instituto de Biologia da UNICAMP, Campinas.

\footnotetext{
${ }^{1}$ Doutoranda do Programa de Pós-graduação de Biologia Vegetal, Instituto de Biologia, Unicamp
} 
A cultura de protoplastos com regeneração de plantas de maracujá foi obtida em P. edulis f. flavicarpa (Manders et al., 1991; D'Utra Vaz et al., Dornelas \& Vieira, 1993) P. amethystina, P. cincinnata, (Dornelas \& Vieira, 1993), P. alata, P. giberti (Dornelas et al., 1995), P. coccinea (Otoni et al., 1995b) e $P$. suberosa (Otoni et al., 1996b). Os explantes usados como fontes de protoplastos foram folhas (Manders et al., 1991; D'Utra Vaz et al., 1993; Dornelas et al., 1995; Otoni et al., 1995b), cotilédones, hipocótilos (Dornelas \& Vieira, 1993) e suspensões celulares (Dornelas et al., 1995).

Segundo Vieira \& Dornelas (1996), o meio adequado para a cultura de protoplastos e o de células em divisão de Passiflora são, respectivamente, o KM8P e o KM8 (Kao \& Michayluk,1975 modificado por Gilmour et al., 1989). Já os calos oriundos das colônias celulares são cultivados em MS suplementado com ANA (5 mg/L) e BA (0,25 mg/L) (D’Utra Vaz et al., 1993; Dornelas e Vieira, 1993) ou em meio MD, desenvolvido por Mourad-Agha \& Dexheimer (1979) (Dornelas et al., 1995). Para a indução de brotos, tem se utilizado MS contendo BA (1,0 a 2,0 mg/L) suplementado ou não com água de coco.

Otoni et al. (1995b) regeneraram brotos de $P$. coccinea a partir de calos oriundos de protoplastos, os quais foram cultivados, a cada 30 dias, em meio MS suplementado com 0,001 mg/L de ANA e 1,0 mg/L de BA ou com 1,0 mg/L de zeatina, ambos adicionados de sacarose a $3 \%(\mathrm{p} / \mathrm{v})$ e ágar a $0,7 \%(\mathrm{p} / \mathrm{v})$. Os ramos regenerados foram alongados em cultivo, a cada 25 dias, em MS suplementado com $1,0 \mathrm{mg} / \mathrm{L}$ de zeatina ou na ausência de reguladores de crescimento. O enraizamento dos ramos foi obtido em MS contendo metade das concentrações de sais, acrescido de sacarose a 2\% (p/v) e 1,0 mg/L de ácido indol-3-butírico (AIB) por 12 dias e transferência para meio de composição similar, mas sem fitorreguladores.

Assim como em outros sistemas de cultura, a idade, o tipo de explante e o genótipo utilizado como fonte de protoplastos podem influenciar no desenvolvimento das culturas e na regeneração de brotos. A regeneração de plantas a partir de protoplastos isolados de tecido cotiledonar de $P$. 
amethystina, $P$. edulis f. flavicarpa e $P$. cincinnata foi avaliada por Dornelas et al. (1995). Os resultados mostraram que 93\% dos calos de $P$. cincinnata regeneraram brotos em MS suplementado com 2,0 mg/L de BA e 10\% (v/v) de água de coco. Esta taxa caiu para $75 \%$ em $P$. amethystina e $48 \%$ em $P$. edulis f. flavicarpa. Otoni et al. (1996b) estudaram a eficiência de plaqueamento (EP), que corresponde à taxa de formação de microcolônias, em cultura de protoplastos derivados de folhas de $P$. suberosa, com 30, 60 e 90 dias de idade. Os autores observaram que os explantes jovens (30 dias) foram mais eficientes na formação de calos e a EP foi de $0,345 \%$, enquanto nas culturas oriundas de explantes com 60 dias a EP foi de $0,235 \%$.

\subsection{Eletroporação de protoplastos}

Protoplastos são células vegetais individualizadas e desprovidas de parede que é eliminada com o auxílio de enzimas pectocelulolíticas. Em condições adequadas de cultura, os protoplastos podem reconstituir a parede celular e regenerar um calo que origina uma nova planta (Fungaro \& Vieira, 1989). Protoplastos de plantas e fungos têm sido estudados desde a década de 60, mormente na Universidade de Nottingham, Inglaterra, onde ocorreram os primeiros isolamentos por ação enzimática (Cocking, 1960). Contudo, somente em 1972 foi relatada a regeneração de uma planta inteira a partir do cultivo de protoplastos (Carlson et al., 1972). Atualmente, poucas centenas de espécies, parte delas de interesse agronômico, podem ser regeneradas a partir de protoplastos, inclusive algumas leguminosas e gramíneas, consideradas recalcitrantes à cultura in vitro.

A eletroporação é uma técnica que permite a transferência de DNA para células protoplastizadas (ou não) e tecidos íntegros. Consiste na indução de poros reversíveis na membrana celular por meio de pulsos elétricos de alta voltagem, permitindo a entrada de macromoléculas para o interior da célula. Com a indução de um campo elétrico em membranas biológicas, que são 
compostas de um mosaico de proteínas e bicamadas de lipídios, as regiões hidrofóbicas dos fosfolipídeos tornam-se polarizadas, fazendo com que aumente o momento dipolo da membrana no sentido do campo elétrico, levando a uma quebra dielétrica e à formação de poros na membrana. A abertura desses poros permite a entrada do DNA na célula hospedeira.

Os fatores experimentais mais importantes na eletroporação são a duração do pulso e a voltagem aplicada. A estabilidade da membrana celular é inversamente proporcional ao seu diâmetro, portanto, a voltagem aplicada pode variar desde 250 a $1500 \mathrm{~V} / \mathrm{cm}$, dependendo da espécie e do explante utilizado como fonte de protoplastos (Rhatus \& Birch, 1991). Um outro fator importante é o tampão de eletroporação, que pode ser de alta, média ou baixa condutividade. Alguns tampões podem ser tóxicos, devido à presença de $\mathrm{KCl}$, $\mathrm{NaCl}, \mathrm{CaCl}_{2}$ e $\mathrm{MgCl}_{2}$, havendo a formação de gás de $\mathrm{Cl}_{2}$ após a eletroporação. Tada et al. (1990) desenvolveram um tampão para eletroporação de protoplastos de arroz, no qual os íons cloreto foram substituídos por ácidos orgânicos, obtendo uma alta freqüência de transformação $\left(10^{-4}\right)$.

Uma vantagem desse procedimento, em relação aos demais sistemas de transformação, é a introdução do DNA exógeno diretamente na célula, que tem potencial inerente para se dividir e formar colônias e calos. Teoricamente, todas as células da microcolônia serão transformadas e, assim, os brotos regenerados serão transgênicos putativos, salvo escapes durante a seleção in vitro. Quecini (1999) obteve uma eficiência de transformação de 36\% a partir de protoplastos eletroporados isolados de Stylosanthes guianensis, enquanto a transformação por biobalística produziu uma eficiência de transformação de $3,47 \%$. Estes cálculos referem-se ao número de brotos transgênicos em relação ao total de brotos regenerados.

Segundo Galun \& Breiman (1997), a eletroporação é uma técnica favorável em todos os casos em que a transformação mediada por Agrobacterium for difícil como, por exemplo, em algumas espécies de alfafa (Kuchuk et al., 1990), soja (Dhir et al., 1991) e arroz (Kisaka et al., 1998). 
A transformação genética por eletroporação de protoplastos tem sido estabelecida para espécies economicamente importantes, entre elas, o milho (D'Halluin et al., 1992), a banana cv. Bluggoe (Sági et al., 1995), Agrostis palustris (Lin et al., 1997; Asano et al., 1998), Stylosanthes guianensis (Quecini et al., 2001; 2002), Ipomoea batata (Okada et al., 2001) e Brassica oleracea (Radchuk et al., 2002). No entanto, para que essa técnica possa ser usada, há necessidade de se estabelecer protocolos eficientes de isolamento de protoplastos, cultura e regeneração de brotos, o que não é usual. Os procedimentos laboratoriais são trabalhosos e o cultivo de células requer conhecimento aprofundado de fisiologia e nutrição in vitro.

Em maracujá, como dito no item 2.2.2, foram estabelecidos protocolos para a regeneração de plantas a partir de protoplastos isolados de $P$. edulis $\mathrm{f}$. flavicarpa, (Manders et al., 1991; D'Utra Vaz et al., 1993; Dornelas et al., 1993) $P$. amethystina, P. cincinata, P. alata, $P$. giberti (Dornelas et al., 1995) e $P$. coccinea (Otoni et al., 1995b).

\subsection{Transformação por Agrobacterium tumefaciens}

Ao gênero Agrobacterium pertencem bactérias de solo, Gran-negativas e, na maioria, fitopatogênicas, que induzem doenças em tecidos vegetais injuriados. Mais de 600 espécies vegetais são susceptíveis à infecção por $A$. tumefaciens e A. rhizogenes, sendo a maior parte delas dicotiledôneas. A formação de tumores resulta de um processo natural de transferência de genes entre a agrobactéria e a célula vegetal (Brasileiro \& Dusi, 1999). Na literatura, estão disponíveis revisões bastante completas sobre o processo biológico da infecção de plantas por Agrobacterium e a conseqüente transferência de DNA bacteriano para o genoma vegetal (Sheng \& Citovsky, 1996; Riva et al., 1998; Gelvin, 2003; Andrade et al., 2003).

A transformação genética mediada por Agrobacterium spp. é a estratégia mais comum usada para transformar plantas, por ser um sistema simples, 
eficiente e que deposita uma única ou poucas cópias do transgene no genoma hospedeiro. Esta vantagem se deve ao fato de que esse é um evento preciso e evolutivamente selecionado (De Block, 1993).

O mecanismo de integração do DNA exógeno é pouco entendido tanto nos eventos de transformação direta (por biobalística ou eletroporação celular) quanto indireta (via Agrobacterium); no entanto, Kohli et al. (2003) afirmam que a maioria dos eventos de integração ocorre em regiões teloméricas e subteloméricas dos cromossomos da planta. Estudos recentes (Gelvin, 2000; Somers \& Makarevitch, 2004; Tzfira et al., 2004) propõem modelos de integração do DNA exógeno em células transformadas por $A$. tumefaciens baseados no entendimento de funções específicas das proteínas envolvidas na transferência e integração do T-DNA. Somers \& Makarevitch (2004) e Tzfira et al. (2004) propõem que o T-DNA se integra por micro-homologia, isto é, por um evento de recombinação ilegítima entre o sítio alvo do genoma e ambas as extremidades do T-DNA, acompanhado por pequenas deleções no DNA da planta. Sabe-se que há maior conservação da borda 5' devido à ligação da proteína VirD2 a esta extremidade do T-DNA, a qual serve para protegê-lo contra a ação de exonucleases da célula hospedeira.

Há muitos exemplos de transformação genética de dicotiledôneas herbáceas por Agrobacterium, e é crescente o número de espécies frutíferas transformadas por este vetor, destacando-se Malus pumila (James et al., 1989; Lambert \& Tepfer, 1992), Vitis vinifera e V. rupestris (Mullins et al., 1990), Actinidia deliciosa (Rugini et al., 1991), Prunus persica (Smigocki \& Hammerschlag, 1991), Prunus domestica (Mante et al., 1991), Prunus armeniaca (Machado et al., 1992), Citrus auratifolia (Moore et al., 1992; PérezMolphe-Balch \& Ochoa-Alejo, 1998), Poncirus trifoliata (Kaneyoshi et al., 1994), Citrus sinensis (Penã et al., 1995a; 1995b), Diospyrus kaki (Nakamura et al., 1998), Persea americana (Cruz-Hernández et al., 1998) e Citrus sinensis cv. Halmlin (Boscariol et al., 2004). 
Há alguns relatos de trabalhos de transformação de Passiflora, porém sem o uso de genes de interesse agronômico. Em um estudo pioneiro, Manders et al. (1994) descrevem a transformação genética de maracujá amarelo pelo método de co-cultivo de discos foliares inoculados com a linhagem GV3111 de A. tumefaciens contendo o vetor pMON200, que carrega o gene nptll, e a obtenção de três plantas resistentes ao antibiótico canamicina. Silva (1998) transformou maracujá amarelo utilizando a estirpe LBA4404 contendo o plasmídeo pBI121, que contém o gene seletivo nptll e o gene repórter uidA, tendo obtido seis plantas transgênicas. O mesmo vetor foi usado por Hall et al. (2000) para transformar explantes cotiledonares de maracujá utilizando as estirpes LBA4404 e AGL1.

Braz (1999) utilizou esse mesmo vetor (pBI121), carregando o gene da capa protéica do vírus PWV (responsável pela doença que causa o endurecimento dos frutos), inserido na estirpe LBA 4404. A estratégia usada para promover a resistência a doenças virais ocorre pela hibridação do RNA viral com o RNA transcrito pelo transgene, induzindo o silenciamento póstranscricional do gene da capa. Para isto, o autor isolou um fragmento do genoma do vírus contendo a região 3' do gene da replicase e a região 5' da proteína capsidial e inseriu no vetor de clonagem. Apesar de não ter observado amplificação do gene de interesse nas plantas regeneradas, os genes uidA e o nptll foram detectados por reação em cadeia da polimerase (PCR). Estes resultados foram suficientes para o autor concluir que as plantas foram transformadas com um gene de interesse agronômico. 


\subsection{Marcadores seletivos em transformação de plantas}

Genes de seleção são aqueles que codificam uma proteína com atividade enzimática ou um produto que irá conferir às células vegetais transformadas resistência a uma determinada substância, geralmente herbicidas e antibióticos. A finalidade do marcador seletivo é permitir que apenas as células transformadas se desenvolvam (Brasileiro \& Dusi,1999).

O gene de seleção deve ser introduzido no genoma da planta juntamente com o gene de interesse. Uma vez ocorrido o evento de transformação, as células transformadas expressam o gene marcador e o seu produto, em contato com o respectivo substrato, permite o desenvolvimento celular normal, enquanto aquelas células não transformadas morrerão. Os agentes de seleção são adicionados às culturas in vitro apenas nas etapas iniciais do processo de transformação (Sawahel, 1994). Como apenas uma pequena proporção de células é transformada nos ensaios laboratoriais, a chance de se recuperar brotos transgênicos sem seleção é muito baixa (Miki \& McHugh, 2003).

Atualmente, 50 genes marcadores usados em plantas transgênicas têm sido avaliados quanto a sua eficiência, biossegurança, aplicações científicas e comercialização (Miki \& McHugh, 2004). Os mais utilizados são: (i) antibióticos, (ii) herbicidas, (iii) suprimentos que servem como fonte de carbono e (v) precursores de fitohormônios.

O uso de genes de resistência a antibióticos de origem bacteriana, expressos sob o controle de promotores de plantas, é eficiente, porém há casos em que a adição de antibiótico ao meio de cultivo interfere negativamente na capacidade de regeneração (Hoffmann \& Vieira, 2000). Os representantes da principal classe de antibióticos, os aminoglicosídeos, são amplamente usados, sendo o mais conhecido a canamicina, que é largamente aplicada como agente seletivo em ensaios de transformação. Outros são: gentamicina, geneticina, neomicina, paromomicina e higromicina (Wilmink \& Dons, 1993). 
Questões ligadas à biossegurança e à aceitação pública dos organismos geneticamente modificados (OGMs), principalmente no que se refere ao uso desses agentes, têm sinalizado para a necessidade de se procurar sistemas alternativos (Smith, 2000, citado por Souza Junior et al., 2001). Segundo Miki \& Mchugh (2004), o uso de genes seletivos que conferem resistência a antibióticos tem levantado interesse a respeito da possível transferência destes genes para bactérias da flora intestinal humana ou animal ou mesmo para células do organismo que se alimenta de OGMs. Esta questão está presente em várias publicações (Dröge et al., 1998; Bennett et al., 2004). Segundo Bennett et al. (2004), a possibilidade do gene de resistência a antibióticos, presente no alimento transgênico, ser transferido para bactérias tem sido demonstrada em laboratório, mas com uma freqüência muito baixa.

Como alternativa, têm-se buscado utilizar outros sistemas de seleção como, por exemplo, genes de resistência a herbicidas (Tabela 1).

O gene bar, isolado de Streptomyces hygroscopicus (Murakani et al., 1986), que codifica a enzima PAT - fosfinotricina-N-acetiltransferase é um dos mais amplamente empregados pela engenharia genética no desenvolvimento de plantas transgênicas (Souza Júnior et al., 2001). O glufosinato de amônio (PPT) ou fosfinotricina atua como agente seletivo neste sistema. Segundo Lindsey (1992), a enzima PAT inativa os herbicidas que apresentam o PPT como composto ativo, mediante sua detoxificação. Esta detoxificação, que é resultante da acetilação do grupamento amino livre presente no PPT, o torna incapaz de competir de forma inibitória com a glutamina sintetase (GS), possibilitando a remoção da amônia tóxica da célula pela conversão de glutamato em glutamina, reação esta catalisada pela GS.

Outros sistemas de seleção se caracterizam por usar genes que agem no desenvolvimento das células, utilizando agentes que não são metabolizados pelas plantas, permitindo que apenas as células transformadas se desenvolvam. Os marcadores utilizados neste caso são dois: o gene $x y / A$, que codifica a enzima xilose isomerase, isolada de Streptomyses rubiginous 
(Haldrup et al., 1998a) e de Thermoanaerobacterium thermosulfurogenes (Haldrup et al., 1998b), o qual foi usado em tabaco e batata (Miki \& Mchugh, 2004) e o gene manA, isolado de Escherichia coli (Negrotto et al., 2000). Este gene codifica a enzima fosfomanose isomerase (PMI) que catalisa a interconversão de manose-6-fosfato em frutose-6-fosfato, o que permite a manose servir como fonte de carbono à célula transformada.

É sabido que uma das grandes desvantagens da utilização de genes de resistência a antibióticos ou herbicidas é que as células estão sujeitas a processos necróticos devido a componentes tóxicos e inibidores de crescimento que são lançados ao redor das células transformadas (Hoffmann \& Vieira, 2000). Outra razão é a baixa regeneração provocada pela ação do antibiótico.

Segundo Boscariol (2004), a vantagem dos genes marcadores xylA e manA em relação aos sistemas baseados em antibióticos ou herbicidas, é que eles são não destrutivos, inibindo o crescimento e o desenvolvimento das células não transformadas pela falta de carboidrato. Este sistema tem sido usado para várias culturas, dentre elas: beterraba (Joersbo et al., 1998), milho (Wang et al., 2000), trigo (Wright et al., 2001), arroz (He et al., 2004) e Citrus (Boscariol, 2004). 
Tabela 1. Herbicidas usados para seleção de plantas transgênicas

\begin{tabular}{|c|c|c|c|c|}
\hline Herbicida & Gene & Enzima & Origem & Genoma \\
\hline Fosfinotricina & pat, bar & $\begin{array}{l}\text { Fosfinotricina- } \\
\text { acetiltransferase }\end{array}$ & $\begin{array}{c}\text { Streptomyces hygroscopicus } \\
\text { Streptomyces } \\
\text { viridochromogenes TU494 }\end{array}$ & Nuclear \\
\hline \multirow[t]{4}{*}{ Glifosato } & $\begin{array}{c}\text { EPSP } \\
\text { sintetase }\end{array}$ & $\begin{array}{l}\text { 5- } \\
\text { Enolpiruvilshikimato } \\
\text {-3-fosfato sintase }\end{array}$ & Petúnia hybrida, Zea mays & Nuclear \\
\hline & AroA & & $\begin{array}{c}\text { Salmonella typhimurium, } \\
\text { Escherichia coli }\end{array}$ & \\
\hline & $\begin{array}{c}\text { Cp4 } \\
\text { epsps }\end{array}$ & & Agrobacterium tumefaciens & \\
\hline & gox & $\begin{array}{c}\text { Glifosato } \\
\text { oxidoredutase }\end{array}$ & Ochrobactrum anthropi & \\
\hline Sulfonilureas & Csr1-1 & Acetolactato sintase & Arabidopsis thaliana & Nuclear \\
\hline Imidazolinonas & Csr1-1 & Acetolactato sintase & Arabidopsis thaliana & Nuclear \\
\hline Oxinils & $b n x$ & Bromoxinil nitrilase & Klebsiella pneumoniae & Nuclear \\
\hline Gabaculina & hemL & $\begin{array}{l}\text { Glutamato-1- } \\
\text { semialdehido } \\
\text { aminotransferase }\end{array}$ & Synechococcus PCC6301 & Nuclear \\
\hline Cianamida & $c a h$ & $\begin{array}{l}\text { Cianamida } \\
\text { hidratase }\end{array}$ & Myrothecium verrucaria & Nuclear \\
\hline
\end{tabular}

Fonte: Miki \& McHugh (2004)

\subsection{Estratégias para obtenção de resistência à bacteriose através da engenharia genética}

As doenças bacterianas, assim como aquelas causadas por vírus e fungos, têm como conseqüência perdas econômicas, sendo as mais problemáticas aquelas de incidência em hortaliças e frutas, pois são alimentos consumidos in natura. Em muitos casos, a aplicação de defensivos químicos, quando possível, não é suficiente para o seu controle (Mourgues et al., 1998). 
Além disso, o uso indiscriminado desses defensivos é prejudicial ao ambiente e ao consumidor.

A busca por fontes naturais de resistência tem proporcionado a seleção de variedades mais resistentes ou tolerantes, seja através de cruzamentos dentro da espécie cultivada, seja pela hibridação com espécies silvestres (Coyne \& Schuster, 1983; Helgeson, 1989). Este procedimento, porém, é limitado a espécies sexualmente compatíveis, podendo ser dificultado por barreiras pré e pós-zigóticas, e requer sucessivas gerações de cruzamentos com a espécie recorrente no sentido de introgredir somente a característica desejada e recuperar a performance da espécie cultivada (Vieira, 1997). Por outro lado, as técnicas de transformação de plantas e de clonagem de genes, assim como os avanços no entendimento das interações patógeno-planta (Kombrink \& Sonssich, 1995; Bent, 1996; Bonas \& Van den Ackerveken, 1997) têm possibilitado o desenvolvimento de plantas resistentes através da engenharia genética, a qual tem a vantagem de introduzir pontualmente um ou poucos genes de resistência na espécie susceptível (Mourgues et al., 1998).

Proteínas bactericidas são importantes componentes do mecanismo de defesa antimicrobiana de muitos grupos de animais, incluindo artrópodes (particularmente insetos), anfíbios e mamíferos. Provavelmente, essas proteínas agem em sinergia, como demonstrado em Hyalophora cecropia onde, após a injeção de bactérias em pupas em estado de diapausa, pelo menos 15 diferentes proteínas foram produzidas na hemolinfa (Hultmak et al., 1980; Boman \& Hultmark,1987). Três tipos de proteínas antibacterianas foram identificadas: as atacinas (P5, A-F), as cecropinas (P9, A-F) e a lisozima (P7) (Dickinson et al., 1988). Esta classe de proteínas, originalmente nomeadas como proteínas imunológicas P1-P9, é parte importante do sistema de defesa de insetos (Boman et al., 1991), possuindo ação bactericida em um grande número de bactérias Gram-negativas. Genes que codificam proteínas bactericidas têm sido clonados a partir de diferentes organismos e expressos 
em plantas na tentativa de conferir resistência a diversas doenças bacterianas (Tabela 2).

Tabela 2. Exemplos de sucesso do melhoramento de plantas para resistência a doenças bacterianas, via transgenia*

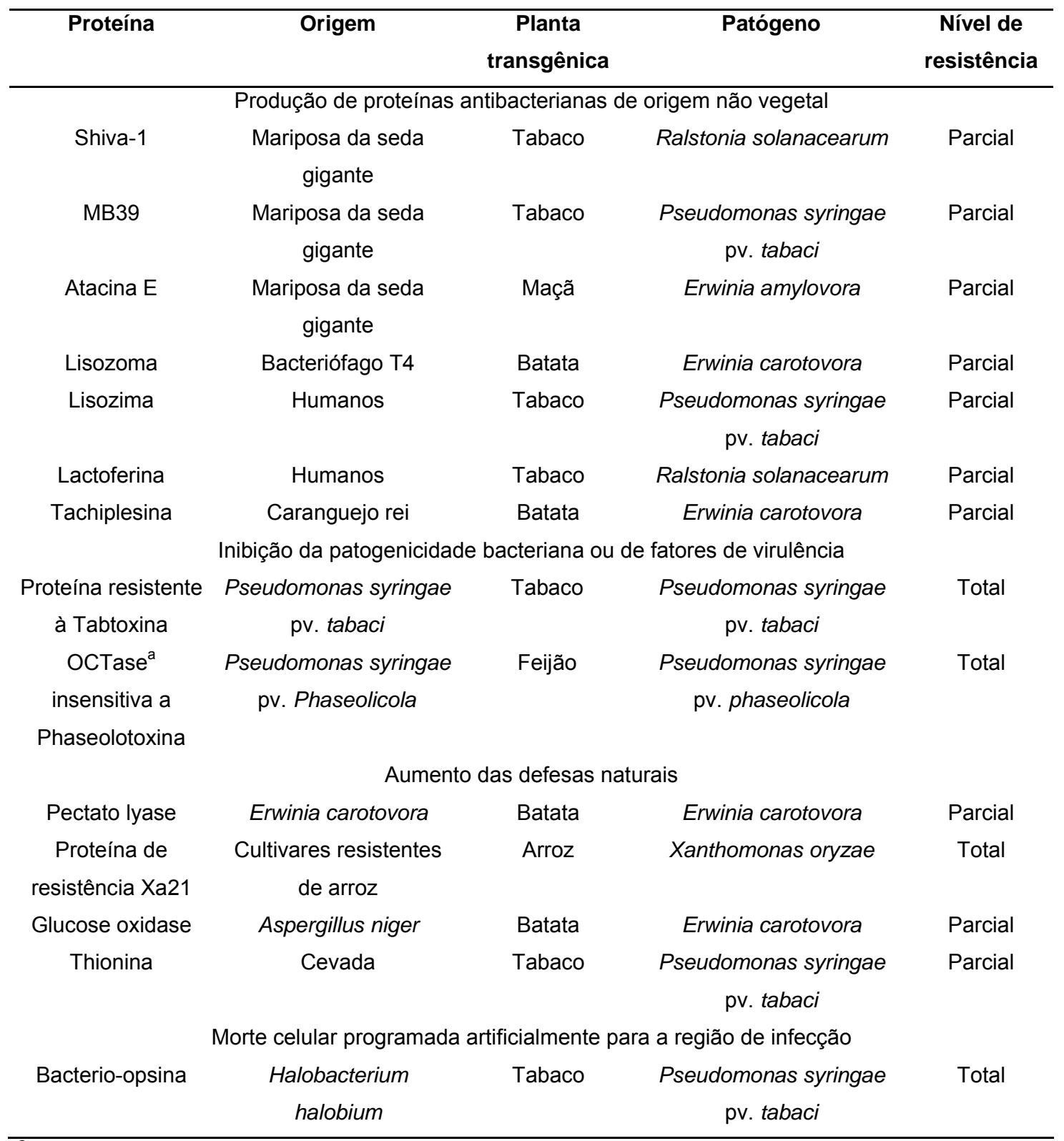

${ }^{a}$ OCTase = ormithina carbamoyltransferase

*Adaptada a partir de Mourgues et al. (1998) 
Como dito, o sistema imunológico de insetos se baseia em polipeptídeos com função antibacteriana como, por exemplo, a proteína atacina. Proteínas similares a atacina também foram encontradas em Drosophila melanogaster (Flyg et al., 1986) e Sarcophaga peregrina (Ando et al., 1987). Por isso, Jaynes et al. $(1987,1990)$ e Casteels et al. (1989) propuseram o uso de genes que codificam proteínas antibacterianas de insetos para produzir plantas transgênicas resistentes.

\subsubsection{Transformação de plantas com o gene da atacina}

As atacinas têm ação bacteriostática em bactérias Gram-negativas (Hultmark et al., 1983, Engstrom et al., 1984, Ando et al., 1988), dentre elas Escherichia coli, Acinetobacter calcoaceticus, Pseudomonas maltophila (Hultmark, 1993), Erwinia amylovora (Norelli et al., 1993) e Xanthomonas axonopodis (Chen \& Kuehnle, 1996; Boscariol, 2004). Agem na parede celular da bactéria, mais especificamente na membrana externa, acarretando uma alteração nas propriedades de permeabilidade, propiciando o acesso de outras proteínas bactericidas como lisozimas e cecropinas que atuam na parede celular e membrana plasmática da bactéria, respectivamente, intensificando, assim, a resistência dos insetos às bactérias (Carlsson et al., 1991).

Seis atacinas foram purificadas, divididas em duas formas, quatro básicas $(A-D)$ e duas ácidas/neutras $(E-F)$, com pesos moleculares variando de 20 a 23 kDa (Hultmark et al., 1983). As seqüências primárias das duas formas apresentam $80 \%$ de homologia. A diferença de potencial isoelétrico entre as formas é explicada pelas quantidades diferentes de ácido aspártico nos peptídeos (Engstrom et al, 1984). Todas as seis proteínas são originárias de dois únicos genes, apresentando variações nas extremidades C-terminal e $\mathrm{N}$ terminal. Por exemplo, dos dois cDNAs da atacina isolados de Hyalophora cecropia (Lee et al., 1983), o correspondente à atacina E codifica uma proteína com 188 aminoácidos que inclui o tetrapeptídio (Ser-Lys-Tyr-Phe) na 
extremidade C-terminal. O outro, codifica para um peptídeo com 184 aminoácidos. As diferenças entre as proteínas se devem a um processamento pós-tradução.

O cDNA que codifica a proteína ácida atacina $E$ foi acoplado a promotores $35 \mathrm{~S}$ e usado na transformação genética de maçã visando obter resistência ao patógeno Erwinia amylovora, agente causal da escaldadura da macieira. Dos 648 segmentos foliares transformados, 36 regenerantes foram resgatados. Estas plantas foram levadas a campo, inoculadas com o patógeno, e apresentaram redução dos sintomas da ordem de 50\%, comparativamente às plantas controle (Norelli \& Aldwincnkle, 1993; Norelli et al.,1994).

O gene da atacina A (att A) foi isolado de Trichoplusia ni por Kang et al. (1996) e possui padrões similares aos de $H$. cecropia. Ao nível de nucleotídeos e de peptídeos, a atacina de $T$. ni mostra alta homologia com a atacina de $H$. cecropia, com $63 \%$ de identidade com a parte madura da proteína. Segundo Carlsson et al. (1998) a ação da atacina em E. coli consiste em um aumento contínuo da permeabilidade da sua membrana externa e a inibição da síntese de proteínas da membrana externa na fase de transcrição, limitando o crescimento da população. Estes autores evidenciaram que a lipo-proteína solúvel presente na membrana (LPS) assume o papel de receptor da atacina, que não precisa entrar na célula bacteriana para manifestar sua atividade. Possíveis danos na membrana interna da bactéria são efeitos subseqüentes da atacina, que tem a habilidade de interferir especificamente na síntese de proteínas da membrana externa, sem penetrar na membrana interna ou citoplasma.

Reynoird et al. (1999) transformaram pereiras com o att E, via $A$. tumefaciens, visando controlar o patógeno $E$. amylovora. A expressão e a presença da proteína foi confirmada por técnicas moleculares e a análise de resistência dos transformantes foi conduzida in vitro, inoculando-se a estirpe do patógeno. Os transformantes mostraram-se resistentes enquanto os não transformantes foram suscetíveis. 
Boscariol (2004) transformou Citrus com o gene att A via Agrobacterium para induzir resistência à bacteriose causada por Xanthomonas axonopodis pv. citri. Posteriormente, plantas transgênicas e não transgênicas foram infectadas com a bactéria. Os resultados mostraram que as plantas transgênicas expressando o gene bactericida apresentaram um período de incubação maior e diâmetros das lesões menores do que aquelas que não continham o gene bactericida.

\subsection{Localização subcelular das proteínas}

A localização específica das proteínas dentro das células é condição essencial para seu funcionamento (Chabregas, 2001), assim como o processo de direcionamento dos peptídeos é bem controlado e eficiente (veja Silva-Filho, 2003). Grande parte das proteínas endógenas relacionadas a patógenos (PR), além de fitoalexinas e ligninas, está localizada no espaço intercelular (apoplasto) onde a bactéria fitopatogênica se multiplica antes de penetrar na célula vegetal (Bogs et al., 1998). A eficiência das plantas transgênicas em manifestar resistência a um patógeno depende do nível de expressão (Florack et al., 1995), estabilidade e localização da proteína na planta (During, 1996). Ko et al. (2000), com o objetivo de obter resistência à Erwinia amylovora, transformaram macieira utilizando os seguintes plasmídeos: p35Satt, que contém o gene att $E$ isolado de $H$. cecropia sob o controle do promotor constitutivo 35S; o p35SAMVatt, o qual contém uma seqüência líder ligada ao gene para aumentar sua expressão; o p35SAMVSPatt, que contém, além da seqüência líder, um peptídeo sinal que direciona a proteína para o apoplasto; e o pLDB15 contendo att E, sob o controle do promotor do gene inibidor de proteinase II (Pin2), induzido por ferimento. A quantidade de atacina presente nas plantas transformadas com os plasmídeos contendo a seqüência lider AMV foi três vezes maior, uma vez que esta seqüência intensifica a transcrição de mRNA. Plantas transformadas com o gene att $E$, o qual foi fusionado ao 
peptídeo sinal (p35SAMVSPatt), apresentaram menores níveis da proteína. No entanto, apresentaram menos sintomas da doença que aquelas que possuíam as construções sem o peptídeo sinal. Estes dados indicaram que a atacina secretada no apoplasto é mais eficiente para reduzir a infecção comparativamente à proteína não exportada, isto é, presente no citoplasma.

Segundo Chabregas (2001), o processo de importação das proteínas para os compartimentos subcelulares é específico. Proteínas direcionadas para as mitocôndrias e cloroplastos apresentam seqüências-líder $\mathrm{N}$-terminais que as direcionam para o envoltório da organela. Proteínas direcionadas para o núcleo apresentam seqüências curtas de quatro a oito aminoácidos básicos localizados em diferentes posições da cadeia polipeptídica. O direcionamento para os peroxissomos é dado por seqüências SKL (serina, lisina e leucina) carboxiterminais. Já para a via secretória, ou seja, proteínas direcionadas para o retículo endoplasmático (RE), aparato de Golgi, membrana plasmática, vesícula de curta duração, além de algumas proteínas vacuolares e proteínas secretadas, duas seqüências de direcionamento foram identificadas: os peptídeos sinais (PS) que são aqueles clivados a partir de uma cadeia nascente, e as âncoras sinais (AS), que não são clivadas liberando as proteínas na membrana do RE.

A atacina A encontra-se na hemolinfa dos insetos, e possui um peptídeo sinal que a transporta para o meio extracelular. Pode-se perguntar: esta seqüência (PS) é reconhecida pela célula vegetal e há o transporte da atacina para o apoplasto?

Diversos estudos têm sido realizados com o intuito de detectar a localização subcelular de proteínas em plantas. Carr et al. (1987), Dumas et al. (1988) e Hosokawa et al. (1988) realizaram estudos para a localização subcelular do grupo das PR-1 em tabaco utilizando técnicas de imunodetecção. Chabregas et al. (2001) estudaram o direcionamento da proteína THI1 de Arabidopsis thaliana para as mitocôndrias e cloroplastos. Para isto, fusionaram 
o gene thi1 com o gene repórter gfp e observaram sua localização em protoplastos de tabaco, utilizando microscópio de fluorescência.

A proteína GFP é uma proteína fluorescente de aproximadamente 27 kDa que emite fluorescência verde quando excitada com luz UV. Esta proteína tem sido muito utilizada como ferramenta para auxiliar nas investigações sobre a localização subcelular de um grande número de proteínas, pois proteínas secretoras e peptídeos sinais podem ser fusionados a ela sem alterar seu direcionamento, permitindo a investigação dos compartimentos in vivo. Esta é uma das mais importantes características da GFP e seus derivados espectrais, especialmente considerando que muitos dos genes repórteres não permitem sua investigação in vivo (Brandizzi et al., 2004).

Vários estudos de direcionamento de proteínas para as mais diversas organelas, usando a fusão com GFP, têm sido realizados (veja Brandizzi et al., 2004). Boevink et al. (1999) estudaram a secreção da proteína GFP para o apoplasto pela fusão do respectivo gene a um PS. Rojo et al. (2002) estudaram a localização extracelular da proteína clavata3 (CLV3) em células meristemáticas de Arabidopsis thaliana. Para isto, os autores isolaram o gene clv3 e o fusionaram com os repórteres gfp e uidA, sob o controle do promotor constitutivo 35S; em seguida, transformaram plantas de $A$. thaliana e observaram a localização de GFP e GUS no apoplasto da planta, mediante microscópio de fluorescência. Estes estudos mostraram que os genes gfp e uidA, mesmo fusionados, se prestam para realizar estudos de direcionamento de proteínas sem que sua via seja alterada.

Marbach (2004) fusionou as seqüências de direcionamento das proteínas FtsHp1, FtsHp2 e FtsHm1 de cana-de-açúcar com o gene da GFP e transformou células da epiderme de cebola para estudar a localização subcelular dessas três proteínas. A epiderme do bulbo da cebola se presta como modelo para estudar a localização subcelular de diversas proteínas fusionadas à GFP, pois é transparente (não possui plastos verdes), facilitando a visualização da proteína sob UV, além da facilidade de sua manipulação para 
estudos in vivo, sem haver a necessidade de técnicas histológicas. No presente trabalho, essa estratégia foi utilizada para verificar a ação do PS nativo da seqüência da atacina $A$ em cebola, usando um cassete de expressão contendo o gene da GFP fusionado a este peptídeo sinal, como será apre: adiante. 


\section{MATERIAL E MÉTODOS}

\subsection{Construção dos vetores pCattA 1302 e pCattA 3300}

O cassete de expressão contendo o gene da atacina $A$ (att A), dirigido pelo promotor $35 \mathrm{~S}$ duplicado e o terminador 35S, foi construído por Takahashi (2002) e inserido no vetor pFF19. O vetor resultante foi denominado pFFattA $(5,25 \mathrm{~Kb})$.

Com o objetivo de obter um vetor contendo o gene de interesse (att A), um gene de seleção em planta e um gene repórter, o cassete de expressão (35S35S - att $A$ - terminador) foi inserido nos vetores binários pCambia $1302 \mathrm{e}$ pCambia 3300 (Cambia GPO Box 3200, Canberra ACT 2601, Austrália), para estudos de expressão transitória e estável, respectivamente. O plasmídeo pCambia 1302 contém o gene de resistência à higromicina (hptll) e o gene reporter gfp que codifica a proteína fluorescente verde (GFP), enquanto o plasmídeo pCambia 3300 contém o gene de resistência ao herbicida fosfinotricina (bar).

Para a construção dos vetores, o cassete de expressão foi liberado de pFFattA por digestão total com enzima HindIII, seguida por uma digestão parcial com 0,4 U de enzima EcoRI para 6,0 $\mu \mathrm{g}$ de DNA plasmidial, por $20 \mathrm{~min}$., a $37^{\circ} \mathrm{C}$, como descrito por Takahashi (2002). O fragmento de $2.100 \mathrm{pb}$, correspondente ao cassete de expressão, foi isolado do gel pelo kit QIAquick Gel Extration Kit (Qiagen) e quantificado em gel de agarose 0,8\% (p/v).

Os vetores pCambia 1302 e 3300 foram hidrolisados com Hindlll e EcoRI. Em seguida foram misturados com o cassete de expressão nas 
proporções de 3:1 e 2:1. A ligação do fragmento com o vetor linearizado foi realizada com a enzima DNA $T_{4}$ ligase (Invitrogen ${ }^{\mathrm{TM}}$ ), conforme sugerido por Sambrook et al. (2001). A reação permaneceu a $20^{\circ} \mathrm{C}$ durante $2 \mathrm{~h}$. Após a ligação, células competentes de E. coli DH5 $\alpha$ (Hanahan, 1983) e JM109 (Yanisch-Perron et al., 1985), previamente preparadas, foram transformadas por choque térmico como descrito por Brasileiro \& Carneiro (1998), e cultivadas em placas contendo meio Luria-Bertani (LB) $\left(10 \mathrm{mg} \mathrm{L}^{-1}\right.$ de triptona; $5 \mathrm{mg} \mathrm{L}^{-1} \mathrm{de}$ extrato de levedura; $10 \mathrm{mg} \mathrm{L}^{-1}$ de cloreto de sódio; $\left.\mathrm{pH} 7,0\right)$ solidificado com ágar $1,5 \%(\mathrm{p} / \mathrm{v})$, contendo canamicina (100 mg/L), X-Gal (1 mg/placa) e IPTG 100 $\mathrm{mM}$ (15 $\mu \mathrm{L} /$ placa). As placas foram incubadas a $37^{\circ} \mathrm{C}$ por $16 \mathrm{~h}$. A confirmação da presença do inserto foi feita via PCR, utilizando os primers que amplificam um fragmento de $350 \mathrm{pb}$, referente às posições 186 (5' GCTGTTCAGCTAGCCAGTCC 3') e 535 (5' TTTGGGAAGTCAGGCATGTT 3') do gene att $A$ (Takahashi, 2002).

Em cada reação de PCR $(25 \mu \mathrm{L})$ usou-se uma colônia bacteriana, $10 \mathrm{mM}$ Tris- $\mathrm{HCl}(\mathrm{pH} 8,4), 50 \mathrm{mM} \mathrm{KCl}, 3,0 \mathrm{mM} \mathrm{MgCl} 2,50 \mu \mathrm{M}$ de cada dNTP, 1,0 U de Taq DNA polimerase (Invitrogen ${ }^{\mathrm{TM}}$ ) e 3,5 pmoles de cada iniciador específico para o gene att $A$. A mistura foi submetida à desnaturação inicial ( $3 \mathrm{~min}$. a $94^{\circ} \mathrm{C}$ ), seguida de 40 ciclos de amplificação ( $1 \mathrm{~min}$. a $94^{\circ} \mathrm{C} ; 1,5 \mathrm{~min}$. a $55^{\circ} \mathrm{C}$ e 1 min. a $72^{\circ} \mathrm{C}$ ) e a uma extensão final $\left(4 \mathrm{~min}\right.$. a $\left.72^{\circ} \mathrm{C}\right)$ em termociclador (MJ Research). Os produtos das reações de PCR foram submetidos à eletroforese em TBE 1X em gel de agarose 1,0\% (p/v) e visualizados após coloração com brometo de etídeo (1 $\mathrm{mg} / 100 \mathrm{~mL}$ ) sob luz UV e fotografados (Gel Doc 2000' BioRad).

Os plasmídeos das colônias PCR+ foram extraídos pelo método de lise alcalina, conforme descrito por Sambrook et al. (2001) e a confirmação da ligação foi realizada pela digestão com as enzimas Xhol, EcoRI e Hindlll e posterior seqüenciamento pelo método de Sanger (1977). 


\subsubsection{Seqüenciamento}

Os insertos dos plasmídeos pCattA 1302 e pCattA 3300, contendo o cassete de expressão, foram seqüenciados utilizando os primers forward 5' TGCTTCCGGCTCGTATGTTG 3' e reverse 5' GCGAAAGGGGGATGTGCTGC 3' desenhados por Takahashi (2002), os quais são complementares às regiões 5' e 3' do Multi Cloning Site (MCS).

A reação de seqüenciamento foi realizada usando-se os procedimentos descritos no manual do kit ABI PRISM ${ }^{\circledR}$ Big Dye ${ }^{T M}$ Teminator Cycle Sequencing ready reaction Kit. Em tubos de 0,2 $\mathrm{mL}$ foram adicionados $2 \mu \mathrm{L}$ de mix Big Dye (que contém dNTP, terminadores ddNTPs associados às substâncias fluorescentes e AmpliTaq DNA polimerse, FS), $1 \mu \mathrm{L}$ de primer foward ou reverse (3,0 pmoles), $1 \mu \mathrm{L}$ de DNA plasmidial (200 a $500 \mathrm{ng}$ ) e água esterilizada (q.s.p.) para completar um volume final de 10,0 $\mu \mathrm{L}$. Cada um dos 30 ciclos de amplificação se deu em termociclador (MJ Research) a $95^{\circ} \mathrm{C}$ por $20 \mathrm{~s}$. , $50^{\circ} \mathrm{C}$ por $15 \mathrm{~s}$. e $60^{\circ} \mathrm{C}$ por $4 \mathrm{~min}$.

Após a amplificação, as amostras foram transferidas para microtubos de $0,65 \mathrm{~mL}$ e foi adicionado $20 \mu \mathrm{L}$ de água estéril e $60 \mu \mathrm{L}$ de isopropnol. A mistura permaneceu por $15 \mathrm{~min}$. à temperatura ambiente (escuro) e foi centrifugada em uma centrífuga de mesa (velocidade máxima) por $30 \mathrm{~min}$. à temperatura ambiente. O sobrenadante foi cuidadosamente descartado e o precipitado lavado com $250 \mu \mathrm{L}$ de etanol 70\% (recém-preparado), seguindo-se outra centrifugação por mais 5 min., sob as mesmas condições, e o sobrenadante descartado. Os tubos, com as tampas abertas, foram colocados por $1 \mathrm{~min}$. em termociclador, previamente aquecido a $90^{\circ} \mathrm{C}$, para a completa evaporação da água. Para o seqüenciamento, as amostras foram ressuspendidas em $3 \mu \mathrm{L}$ de tampão contendo 5 partes de formamida e 1 parte de tampão de carregamento (0,25\% azul de bromofenol, 0,25\% xileno cianol e $40 \%$ sacarose), o DNA foi desnaturado à $98^{\circ} \mathrm{C}$ por 2 min e $1 \mu \mathrm{L}$ de cada amostra foi aplicada no gel. 
O seqüenciamento automático (sequenciador de DNA ABI PRISM 377) foi realizado no Departamento de Entomologia, Fitopatologia e Zoologia Agrícola da ESALQ, sob a supervisão do Prof. Dr. Luiz Eduardo Aranha Camargo.

Os clones positivos foram estocados em glicerol a $-80^{\circ} \mathrm{C}$. Os DNAs plasmidiais, pCattA 1302 e pCattA 3300 foram purificados por método de lise alcalina usando o kit Plasmid Mini Kit (Qiagen). A quantificação foi feita em gel de agarose $1,0 \%(\mathrm{p} / \mathrm{v})$ em TBE $1 \mathrm{X}$ e o DNA estocado a $-20^{\circ} \mathrm{C}$.

\subsection{Direcionamento da proteína atacina A}

\subsubsection{Construção dos vetores pSPattA 1303 e pattA 1303}

O gene att A clonado no vetor pCambia 3300 possui uma seqüência que codifica para um peptídeo sinal de $54 \mathrm{pb}$ (SP), o qual direciona a proteína para a hemolinfa do inseto. Ao analisar a seqüência da proteína pelo programa SignalP 3.0 (http://www.cbs.dtu.dk/services/TargetP/) obteve-se a informação que esta proteína possui $95,4 \%$ de confiabilidade de ser direcionada para o meio extracelular (apoplasto). Para confirmar este direcionamento, plasmídeos contendo o gene att A com e sem o peptídeo sinal nativo foram construídos. Inicialmente, três primers (29 e $30 \mathrm{pb}$ ) foram desenhados (dois forward e um reverse) baseando-se na seqüência da preproatacina $A$ correspondente à sequência de Trichoplusia ni (GenBank NCBI U46130). Os primers forward $1 \mathrm{e}$ 2 foram desenhados para amplificar a seqüência com (765 pb) e sem (711 pb) o peptídeo sinal, respectivamente. Para incluir os sítios de restrição para clonagem, os primers forward e reverse foram desenhados para conter o sítio Ncol (5' CCATGG 3') e Spel (5' ACTAGT 3') nas extremidades 5' e 3' da seqüência do gene att $A$, respectivamente. Para manter a fase de leitura, dois nucleotideos (AA ou $\mathrm{CC}$ ) foram adicionados logo após o sítio de restrição $\mathrm{Ncol}$. O sítio de restrição Spel (reverse) substituiu o códon de terminação para manter 
a fase de leitura com o gene uidA presente no vetor pCambia 1303. Este vetor possui os genes repórteres uidA e gfp fusionados sob o controle do promotor $35 \mathrm{~S}$ e o gene seletivo para plantas nptll (Figura 2). Nas extremidades dos primers foram adicionados dois nucleotídeos CC para facilitar o ancoramento das enzimas de restrição (Tabela 3).

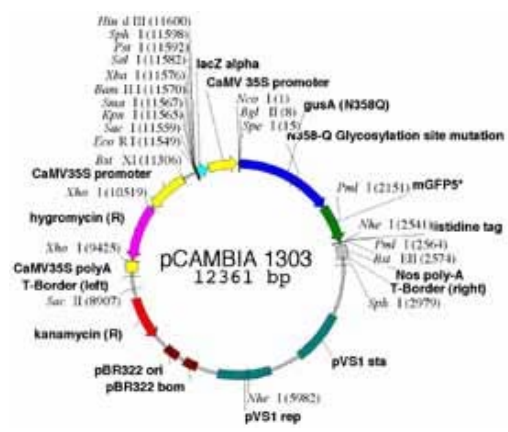

Figura 2 - Plasmídeo pCambia 1303 utilizado nas fusões das seqüências do gene att $A$ com e sem peptídeo sinal

Tabela 3. Seqüência dos primers desenhados para clonar o gene att $A$, contendo ou não o peptídeo sinal, no vetor pCambia 1303. Os sítios de restrição estão sublinhados. Números sobrescritos correspondem à posição original do gene att A (GenBank NCBI U46130)

\begin{tabular}{|c|c|}
\hline Primer & Seqüência $\left(5^{\prime} \Rightarrow 3^{\prime}\right)$ \\
\hline Forward 1 & CCC $\underline{\text { CCA TGG AAA }}{ }^{1}$ TGT TCA CCT ACA AAT TG \\
\hline Forward 2 & 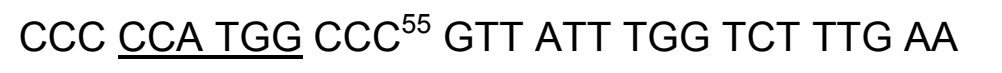 \\
\hline Reverse & CCC $\underline{A C T ~ A G T}^{763}$ CCA CTT ATT ACC AAA AGA CCG \\
\hline
\end{tabular}


Os fragmentos foram amplificados por PCR. Cada reação (50 $\mu \mathrm{L})$, contendo 500 ng de DNA plasmidial pCattA 3300, 10 mM Tris- $\mathrm{HCl}(\mathrm{pH} \mathrm{8,4),} 50$ $\mathrm{mM} \mathrm{KCl}, 3,0 \mathrm{mM} \mathrm{MgCl}$, $50 \mu \mathrm{M}$ de cada dNTP, 1,0 $\mathrm{U}$ de Taq polimerase (Invitrogen ${ }^{\mathrm{TM}}$ ) e 30,0 pmoles de cada iniciador específico para o gene att A, foi submetida à desnaturação ( $3 \mathrm{~min}$. a $\left.94^{\circ} \mathrm{C}\right)$, seguida de 35 ciclos de amplificação (1 min. a $94^{\circ} \mathrm{C} ; 1 \mathrm{~min}$. a $50^{\circ} \mathrm{C}$ e $2,5 \mathrm{~min}$. a $72^{\circ} \mathrm{C}$ ) e à extensão final (3 min. a $72^{\circ} \mathrm{C}$ ) em termociclador (MJ Research). Uma alíquota $(2 \mu \mathrm{L})$ dos produtos das reações de PCR foi submetida à eletroforese $(3 \mathrm{~V} / \mathrm{cm})$ em gel de agarose $0,8 \%$ $(p / v)$.

Após a confirmação, essas seqüências foram digeridas totalmente pela enzima de restrição Spel (extremidade 3') e parcialmente pela enzima Ncol (extremidade 5') utilizando 1,0 unidade de enzima por 10, 20 e $30 \mathrm{~min}$. (37 $\mathrm{C}$ ) e submetidas à eletroforese em gel de agarose $0,8 \%(\mathrm{p} / \mathrm{v})$. As bandas de $766 \mathrm{pb}$ e 712 pb correspondentes ao gene att A com SP e sem SP, respectivamente, foram extraídas do gel usando o QIAquick ® Gel Extraction Kit (Quiagen).

O vetor binário pCambia 1303 foi submetido à digestão total com essas enzimas e os fragmentos inseridos nas extremidades dando origem ao cassete 35S-attA:uidA:gfp. A ligação foi realizada como descrita no item 3.1, e os produtos de ligação foram transferidos para E. coli (JM109) pelo método de choque-térmico. As bactérias foram cultivadas em placas com LB sólido (ágar a $15 \%$ ) contendo canamicina (100 mg/L) e incubadas a $37^{\circ} \mathrm{C}$ por $16 \mathrm{~h}$.

A primeira confirmação da construção foi realizada por PCR diretamente das colônias bacterianas, utilizando os primers que amplificam o gene att $A$. Os plasmídeos das colônias PCR+ foram extraídos pelo método de lise alcalina e a confirmações adicionais da ligação foram realizadas por: (i) digestão com as enzimas de restrição Spel e Ncol e (ii) seqüenciamento utilizandos os primers 5' GCT GTT CAG CTA GCC AGT CC 3' na posição 186, 5' ACA TCA GCG CTA AAG CCT TC 3' na posição 487 e 5' TTT GGG AAG TCA GGC ATG TT3' na posição 535 (Takahashi, 2002). A reação para o seqüenciamento foi feita como descrito no item 3.1.1. 
Após o seqüenciamento, os DNAs plasmidiais dos clones positivos, pSPattA 1303 e pattA 1303, foram purificados por método de lise alcalina. A quantificação foi feita em gel de agarose $1,0 \%(p / v)$ e o DNA estocado a $-20^{\circ} \mathrm{C}$.

\subsubsection{Transformação por biobalística das células da epiderme de cebola}

Para confirmação do direcionamento da proteína GFP ( $g f p)$ e dos cristais de GUS (uidA) foi utilizado um tecido vegetal transparente (epiderme de cebola) que permitisse a sua visualização no interior ou fora das células, conforme a construção usada na transformação.

Para o bombardeamento da epiderme de cebola foi usado o equipamento PDS 1000/He (Bio Rad), empregando gás Hélio sob alta pressão como gerador de onda de choque para aceleração de micropartículas, detalhadamente descrito em Kikkert (1993).

A precipitação do DNA sobre as micropartículas de tungstênio M10 (Sylvania) foi realizada pelo método $\mathrm{CaCl}_{2}$ /espermidina, conforme descrito em Smith et al. (1992), Aragão et al. (1993; 1996) e Quecini (1999). A umidade relativa do ar na sala estava a $40 \%$ e o vácuo na câmara do equipamento, superior a $65 \mathrm{~mm}$ de $\mathrm{Hg}$. Os parâmetros físicos utilizados foram: 900 psi de pressão de gás Hélio e $6,0 \mathrm{~cm}$ de distâncias de vôo das micropartículas. Os parâmetros de distâncias entre o disco de ruptura e macrocarreador e entre a membrana macrocarreadora e a tela de retenção foram de $6,35 \mathrm{~mm}$ e $10 \mathrm{~mm}$, respectivamente.

Os explantes (epiderme de cebola) foram cortados em tamanhos de $2 \times 2$ $\mathrm{cm}$, posicionados na região central das placas de Petri $(9 \mathrm{~cm})$ e bombardeados. Posteriormente, foram transferidos para BOD sob temperatura de $25^{\circ} \mathrm{C}$ por 24 h.

Para a observação da expressão transiente do gene repórter gfp, a epiderme do explante foi retirada, colocada em uma lâmina de vidro e coberta com lamínula, e submetida à plasmólise em uma solução $1 \mathrm{M}$ de $\mathrm{NaCl}_{2}$. 
Observou-se a expressão da GFP sob microscópio (Axiophot 2 Zeiss) com filtro FITC (excitação 470 nm; emissão 520 nm).

Para observação da expressão do gene uidA, a epiderme do explante foi retirada e colocada em tampão de reação contendo o substrato cromogênico 5bromo-4-cloro-3-indolil glucuronídeo (X-Gluc) (Chemica Alta DTD), preparado de acordo com Brasileiro e Carneiro (1998), adicionado de $20 \%$ de metanol $(\mathrm{v} / \mathrm{v})$ a fim de suprimir a atividade das $\beta$-glucuronidases endógenas (Kosugi et al., 1990). A epiderme foi mantida a $37^{\circ} \mathrm{C}$ por $16 \mathrm{~h}$ e observada sob microscopia óptica.

\subsection{Cultura in vitro}

\subsubsection{Material vegetal}

Em todos os ensaios experimentais foram utilizados explantes oriundos de plantas germinadas in vitro de Passiflora edulis f. flavicarpa Deg. variedade FB-100 Maguary. As sementes foram gentilmente cedidas pelo Sr. José Rafael da Silva, da Viveiros Flora Brasil Ltda. Este genótipo provém de 16 anos de melhoramento genético e sua principal destinação é para indústria de suco. Possui alto rendimento de suco (superior a 42\%) e um Brix acima de 14,5 e um potencial produtivo de 50 toneladas por hectare. A variedade FB-100 é de característica rústica e tem boa estabilidade produtiva. Os frutos são desuniformes em tamanho e forma e a cor da polpa é amarelo-alaranjado. 


\subsubsection{Germinação in vitro de sementes de maracujá amarelo}

As sementes foram desinfestadas com Benomil 0,1\%, esterilizadas com álcool 70\% e hipoclorito de sódio ( $\mathrm{NaOCl}$ ) 2,0\% e lavadas sucessivamente com água destilada, deioniozada e esterilizada. As sementes foram escarificadas e inoculadas em meio MS/2 (Murashige \& Skoog, 1962) contendo a metade da concentração original de sais e componentes orgânicos. A germinação se deu a $25 \pm 2^{\circ} \mathrm{C}$, fotoperíodo de $16 \mathrm{~h}$ e intensidade luminosa de $25 \mu \mathrm{mol} \cdot \mathrm{m}^{-2} \cdot \mathrm{s}^{-1}$. Foi avaliado o tempo e a porcentagem de germinação.

\subsubsection{Eletroporação de protoplastos}

\subsubsection{Isolamento, cultura e regeneração de protoplastos de maracujá amarelo}

Para o isolamento de protoplastos foram utilizados, em média, 0,25 g de explantes cotiledonares após 5 a 10 dias da germinação. Adotou-se o procedimento descrito por Monteiro et al. (2003) utilizando-se uma solução enzimática contendo 2,0\% de Cellulase R10 e 0,4\% de Macerozyme R10 e solução de lavagem CPW-13 (Frearson et al., 1973).

Para o plaqueamento dos protoplastos adotou-se a densidade de $1 \times 10^{5}$ protoplastos/mL de meio; para o cultivo dos protoplastos foi utilizado o sistema líquido e em gotas de agarose (0,6\%, Sigma Tipo VII), tal como descrito por Monteiro et al. (2003). Neste último, após a mistura de protoplastos com a agarose, as gotas foram banhadas com $3 \mathrm{~mL}$ de meio líquido K8P (Kao, 1977, modificado por Gilmour et al., 1989). As placas foram seladas com parafilme e incubadas no escuro por 6 dias; em seguida, foram transferidas para ambiente sob $25 \mu \mathrm{M} . \mathrm{m}^{-2} . \mathrm{s}^{-1}$ de intensidade luminosa, a $25^{\circ} \mathrm{C}$. 
Para a redução da osmolaridade do meio de cultura, foi substituído $1 \mathrm{~mL}$ de meio líquido (K8P) por meio para células (K8) após 7, 14 e 21 dias, numa proporção de 2:1, 1:1 e 0:1 de cada meio, respectivamente. Este procedimendo foi realizado para ambos os sistemas de cultivo e avaliada a eficiência de plaqueamento (EP), ou seja, o número de colônias formadas em relação ao número de protoplastos plaqueados, a cada 7 dias, sob microscópio ótico invertido.

Após 28 dias de cultura, os microcalos derivados foram transferidos para meio MS contendo 0,1 e/ou 0,5 mg/L de BA e 5,0 mg/L de ANA por 28 dias, no escuro e, posteriormente, sob $25 \mu \mathrm{M} . \mathrm{m}^{-2} \cdot \mathrm{s}^{-1}$ de radiação luminosa para promover o desenvolvimento dos calos. Para a avaliação, foram mensurados o peso inicial e o peso final dos calos aos 30 dias. Em seguida, foram transferidos para placas $(9 \mathrm{~cm})$ contendo MS suplementado de 0,5 a 2,0 mg/L de BA e 0 a $10 \%$ de água de coco sob iluminação de $25 \mu \mathrm{M} \cdot \mathrm{m}^{-2} \cdot \mathrm{s}^{-1}$ e subcultivados a cada 28 dias para indução de brotos. As avaliações foram feitas sob microscópio estereoscópico, contando-se o número de calos apresentando brotos.

Após a formação de brotos, estes foram repicados e transferidos para meio MS, MS/2 ou MSM (Monteiro et al., 2000), em frasco (6 x $9 \mathrm{~cm}, 200 \mathrm{~mL}$ ) ou magenta $(7 \times 7 \mathrm{~cm}, 300 \mathrm{~mL})$ para alongamento e desenvolvimento de raízes.

Os experimentos obedeceram ao delineamento inteiramente casualizado, com 3 repetições. Cada parcela foi constituída por 9 (quando utilizou-se placa de Petri) ou 4 explantes (frasco ou magenta). Os dados foram analisados usando o programa SAS, Versão 6.11 (SAS Institute, Cary, NC). Para a comparação das médias foi adotado o teste Tukey $(P \leq 0,05)$.

\subsubsection{Otimização da concentração de higromicina e fosfinotricina para seleção dos transformantes}


A determinação da concentração de higromicina e fosfinotricina foi realizada como descrito a seguir:

Os protoplastos foram isolados e cultivados como descrito no item 3.3.3.1. Após 14 dias de cultivo, foram aplicadas doses de 0 a $10 \mathrm{mg} / \mathrm{L}$ de higromicina (Sigma Chemical Company, USA) e de 0 a $0,5 \mathrm{mg} / \mathrm{L}$ de fosfinotricina (Finale ${ }^{\circledR}$ ). Em seguida, as placas foram incubadas no escuro por 5 dias e cultivadas sob $25 \mu \mathrm{M} . \mathrm{m}^{-2} \cdot \mathrm{s}^{-1}$ de intensidade luminosa. A avaliação foi realizada aos 7, 14 e 21 dias após a aplicação do agente seletivo, a partir da observação de 10 campos de cada placa ao microscópio óptico invertido, quanto à EP e ao aspecto clorótico dos calos. Os experimentos obedeceram ao delineamento inteiramente casualizado, com 3 repetições. Os dados foram analisados como descrito no item 3.3.3.1.

\subsubsection{Otimização das condições de eletroporação de protoplastos}

Para os experimentos de transformação por eletroporação de protoplastos foram utilizados: $20 \mu \mathrm{g}$ de plasmídio pCattA 1302, cubetas de 0,4 cm de distância entre os eletrodos e tampão de eletroporação ASP (Tada et al., 1990) contendo 0,4 e 0,7 M de manitol. Foi utilizado o equipamento comercial Gene Pulser II (Bio Rad) com extensão de capacitância para aplicar descarga elétrica proveniente de capacitor de $900 \mu \mathrm{F}$ associada a campos elétricos de $200,250,315,375$ e $440 \mathrm{~V} / \mathrm{cm}$ e descargas elétricas provenientes de capacitores de 800 e $1000 \mu \mathrm{F}$ associadas a campos elétricos de 200 e 250 $\mathrm{V} / \mathrm{cm}$.

Após o tratamento elétrico, os explantes permaneceram em recipientes contendo gelo por $30 \mathrm{~min}$. A avaliação da viabilidade dos protoplastos foi realizada imediatamente, pela observação ao microscópio fluorescente (Axiophot 2 Zeiss) com filtro FITC (excitação 470 nm; emissão $520 \mathrm{~nm}$ ) da mistura de uma suspensão de protoplastos com uma solução FDA (Power \& Chapman, 1985) a 0,1\% (p/v). Para a avaliação da eficiência da transformação, 
as células foram armazenadas por $48 \mathrm{~h}$, e submetidas a observações sob microscópio fluorescente para detecção de protoplastos com expressão da GFP. Foram realizadas 3 repetições de cada tratamento. As avaliações foram feitas ao microscópio a partir de 10 campos da lâmina. Os dados foram analisados como descrito no item 3.3.3.1.

\section{4 Transformação de maracujá amarelo por Agrobacterium tumefaciens}

\subsubsection{Transformação das linhagens desarmadas de $A$. tumefaciens}

As linhagens desarmadas de A. tumefaciens LBA 4404 (Hoekema et al., 1983) e EHA 105 (Hood et al., 1993) foram transformadas pelo método de choque térmico com o plasmídeo pCambia 3301, que contém e o gene seletivo bar e o gene repórter uidA (o qual apresenta um íntron na extremidade 5'), e com o plasmídeo pCattA 3300. Foi utilizado $1,0 \mu \mathrm{g}$ de DNA plasmidial para 100 $\mu \mathrm{L}$ de células competentes de $A$. tumefaciens. Após a transformação, as bactérias foram cultivadas em placas com LB sólido acrescido de $25 \mu \mathrm{g} / \mathrm{L}$ de rifampicina e $100 \mu \mathrm{g} / \mathrm{L}$ de canamicina visando à seleção dos transformantes da linhagem EHA 105 e $25 \mu \mathrm{g} / \mathrm{L}$ de rifampicina, $100 \mu \mathrm{g} / \mathrm{L}$ de streptomicina e 100 $\mu \mathrm{g} / \mathrm{L}$ de canamicina para a seleção dos transformantes da linhagem LBA 4404. As placas foram incubadas a $28^{\circ} \mathrm{C}$ por $48 \mathrm{~h}$. $O$ evento de transformação com o vetor pCattA 3300 foi confirmado por PCR (ver item 3.1) utilizando primers que amplificam uma região de $765 \mathrm{pb}$ do gene att $\mathrm{A}$ como descrito no item 3.2.1.

Para confirmação da transformação com o vetor pCambia 3301 foram usados os primers 5' CCTGTAGAAACCCCACAACG 3' e 5' $^{\prime}$ TGCAGCGCTACCTAAGGCCG 3', desenhados por Quecini (1999), que amplificam uma região de $743 \mathrm{pb}$ do gene uidA. Para a amplificação foi utilizado o seguinte programa: desnaturação inicial por $5 \mathrm{~min}$. a $95^{\circ} \mathrm{C}$, seguida de 25 ciclos de amplificação $\left(1 \mathrm{~min}\right.$. a $94^{\circ} \mathrm{C} ; 1 \mathrm{~min}$. a $45^{\circ} \mathrm{C}$ e $1,5 \mathrm{~min}$. a $\left.72^{\circ} \mathrm{C}\right)$ e 
extensão final por $7 \mathrm{~min}$. a $72^{\circ} \mathrm{C}$ em termociclador (MJ Research). Os produtos das reações de PCR foram submetidos à eletroforese em gel de agarose 1,0\% $(p / v)$.

As colônias com o plasmídeo foram estocadas em glicerol $50 \%$ a $-80^{\circ} \mathrm{C}$. O estoque de trabalho foi mantido em placas com LB sólido acrescido de 25 $\mu \mathrm{g} / \mathrm{L}$ de rifampicina e $100 \mu \mathrm{g} / \mathrm{L}$ de canamicina para a linhagem EHA 105 e 25 $\mu \mathrm{g} / \mathrm{L}$ de rifampicina, $100 \mu \mathrm{g} / \mathrm{L}$ de streptomicina e $100 \mu \mathrm{g} / \mathrm{L}$ de canamicina para a linhagem LBA 4404.

\subsubsection{Cultura de explantes}

Com o intuito de escolher o explante mais adequado para a transformação de maracujá amarelo via $A$. tumefaciens, discos foliares de 0,7 $\mathrm{cm}$ de diâmetro, cotilédones de $1,0 \mathrm{~cm}^{2}$ e hipocótilos de $1,0 \mathrm{~cm}$ de tamanho foram excisados de plantas assépticas (15 a 20 dias de idade) e cultivados em MS com 1,0 mg/L de BA e 5\% de água de coco, solidificado com agar (0,6\%, $\mathrm{p} / \mathrm{v})$.

O ensaio foi conduzido em placas de Petri $(9 \mathrm{~cm})$, em delineamento inteiramente casualizado, com 3 repetições. Cada parcela foi composta por uma placa contendo 9 explantes. As placas foram incubadas sob luz branca fluorescente $\left(25 \mu \mathrm{mol} . \mathrm{m}^{-2} \cdot \mathrm{s}^{-1}\right)$ a $25^{\circ} \mathrm{C} \pm 2^{\circ} \mathrm{C}$ e fotoperíodo de $16 \mathrm{~h}$. Os explantes foram avaliados aos 10, 20 e 30 dias de cultivo, sob lupa quanto à regeneração de brotos. Os dados foram analisados comforme descrito no item 3.3.3.1. 


\subsubsection{Infecção de explantes de maracujá amarelo por A. tumefaciens}

A transformação genética dos explantes de maracujá foi baseada no protocolo de Boscariol (2004), com modificações. Colônias únicas das linhagens LBA 4404 e EHA 105, contendo os plasmídeos pCambia 3301 e pCattA 3300 , foram crescidas em $5 \mathrm{~mL}$ de meio LB líquido a $28^{\circ} \mathrm{C}$ por $24 \mathrm{~h}$, sob agitação (150 rpm). Em seguida, foram coletados $50 \mu \mathrm{L}$ da cultura bacteriana e inoculados em $50 \mathrm{~mL}$ de LB líquido e cultivados por $12 \mathrm{~h}$. A concentração de células da cultura foi quantificada em espectrofotômetro $(600 \mathrm{~nm})$. A cultura foi submetida à centrifugação e as células ressuspendidas a um volume de $\mathrm{MS}(\mathrm{pH}$ $5,6)$ de modo que a concentração de bactérias ficasse em torno de $5 \times 10^{8}$ unidades formadoras de colônias (UFC)/mL.

Como fonte de explantes, foram utilizados discos foliares de $0,7 \mathrm{~cm}$ de diâmetro e hipocótilos cortados a $1,0 \mathrm{~cm}$ de tamanho, obtidos a partir de plantas assépticas de maracujá com 20 dias. Os explantes foram co-cultivados com a cultura bacteriana ( $A$. tumafaciens) em MS adicionado de $100 \mu \mathrm{M}$ de acetoseringona por $20 \mathrm{~min}$. Os explantes foram transferidos para meio MS solidificado com ágar $(0,6 \%, \mathrm{p} / \mathrm{v})$ contendo $1,0 \mathrm{mg} / \mathrm{L}$ de $\mathrm{BA}, 5 \%$ de água de coco e $100 \mu \mathrm{M}$ de acetoseringona em pH 5,6. A incubação foi feita a $24^{\circ} \mathrm{C}$ por 3 dias, no escuro.

\subsubsection{Análise ultra-estrutural das microfibrilas de celulose}

Para análise da formação de microfibrilas de celulose pelo Agrobacterium, explantes foliares infectados com as duas linhagens de $A$. tumefaciens foram fixados, após 72 h, em solução de Karnovsky (Karnovsky, 1965), desidratados em série etílica, secos ao ponto crítico com dióxido de carbono, montados sobre suportes de alumínio e recobertos com uma camada 
de ouro de 30 a $40 \mathrm{~nm}$. As observações foram realizadas sob microscopia eletrônica de varredura (LEO VP 435) de pressão variável.

\subsubsection{Ensaio histoquímico e localização anatômica da expressão do gene uidA}

Os explantes foliares e hipocotiledonares infectados com as linhagens LBA 4404 e EHA 105 de A. tumefaciens contendo o plasmídeo pCambia 3301 foram analisados para detecção histoquímica da atividade da enzima $\beta$ glucuronidase (Gus), 72 h (expressão transiente) e 30 dias (expressão estável) após a transformação, utilizando o tampão de reação X-Gluc. Os tecidos foliares e hipocotiledonares foram incubados no tampão de reação (16 h) a $37^{\circ} \mathrm{C}$, no escuro. Os pigmentos dos explantes foram removidos por lavagens sucessivas com etanol $70 \%$ (v/v) e a expressão de GUS, nos explantes, observada sob lupa. O experimento foi conduzido em tubos eppendorfs, com 3 repetições, sendo que cada tubo continha seis explantes. Os dados foram analisados conforme descrito no item 3.3.3.1.

A análise histológica da expressão estável foi feita de maneira a identificar áreas de coincidência entre a formação de gemas adventícias e a expressão do gene uidA. Explantes hipocotiledonares, aos 20 dias de cultivo em meio de regeneração, demonstrando reação positiva, ou seja, tecidos com pontos azuis, foram desidratados em série etílica e infiltrados em resina metacrilato (Leica). As secções longitudinais $(10 \mu \mathrm{m})$ foram feitas em micrótomo rotatório e visualizadas sob microscopia óptica. 


\subsubsection{Regeneração de plantas a partir de explantes de maracujá amarelo} infectados com $A$. tumefaciens

Explantes foliares e hipocotiledonares, de maracujá amarelo, após serem co-cultivados com as linhagens LBA 4404 e EHA 105 de A. tumefaciens contendo o plasmídeo pCattA 3300, como descrito no item 3.4.3, foram transferidos para meio MS solidificado contendo $250 \mathrm{mg} / \mathrm{L}$ de cefotaxima, $\mathrm{pH}$ 5,8 e cultivados sob radiação luminosa de $25 \mu \mathrm{mol} \cdot \mathrm{m}^{-2} \cdot \mathrm{s}^{-1}$, a $25 \pm 2^{\circ} \mathrm{C}$ e fotoperíodo de $16 \mathrm{~h}$. Aos 10 dias após a transformação, os explantes foliares foram transferidos para meio MS sólido contendo $250 \mathrm{mg} / \mathrm{L}$ de cefotaxima e 0,1 $\mathrm{mg} / \mathrm{L}$ de herbicida Finale ${ }^{\circledR}$, o qual contém a fosfinotricina como princípio ativo, enquanto os explantes hipocotiledonares foram transferidos para este mesmo meio sem a presença do agente seletivo. A concentração de herbicida foi estabelecida previamente por Castro et al. (2003) como sendo suficiente para selecionar brotos transgênicos para o gene bar, oriundos de explantes foliares de maracujá amarelo. Os explantes foram cultivados como descrito no item 3.3.4.2. O subcultivo se fez a cada 28 dias. Os explantes que apresentaram brotos foram individualizados em meio de enraizamento (MS/2).

\subsubsection{Análise molecular dos transformantes}

\subsubsection{Via reação em cadeia da polimerase (PCR)}

A PCR foi realizada visando à confirmação da inserção dos transgenes. O DNA genômico dos transgênicos putativos e das plantas matrizes (doadoras de explante) foram extraídos conforme descrito por Edwards et al. (1991) a partir de folhas excisadas de plantas mantidas in vitro. A PCR foi feita utilizando os primers descritos no item 3.2.1, que amplificam um fragmento $765 \mathrm{pb}$ referente ao gene att $A$ usando-se o seguinte protocolo: 
Cada reação $(25 \mu \mathrm{L})$ contendo 30 ng de DNA genômico, 10 mM Tris-HCl $(\mathrm{pH}$ 8,4), $50 \mathrm{mM} \mathrm{KCl}, 3,0 \mathrm{mM} \mathrm{MgCl}$, $50 \mu \mathrm{M}$ de cada dNTP, 1,0 U de Taq polimerase (Invitrogen ${ }^{\mathrm{TM}}$ ) e 1,0 pmol de cada iniciador específico para o gene att A. A mistura foi submetida à desnaturação (3 min. a $\left.94^{\circ} \mathrm{C}\right)$, seguida de 35 ciclos de amplificação ( 1 min. a $94^{\circ} \mathrm{C} ; 1$ min. a $50^{\circ} \mathrm{C}$ e $2,5 \min$. a $72^{\circ} \mathrm{C}$ ) e à extensão final $\left(3 \mathrm{~min}\right.$. a $\left.72^{\circ} \mathrm{C}\right)$ em termociclador.

Os produtos das reações de PCR foram submetidos à eletroforese em gel de agarose $1,0 \%(\mathrm{p} / \mathrm{v})$.

\subsubsection{Análise dos transcritos de att A por RT-PCR}

Visando comprovar a transcrição do gene att $A$, plantas transgênicas PCR+ para o vetor pCattA 3300 foram submetidas a análises por RT-PCR. Os passos desta técnica estão descritos a seguir:

Extração do RNA total: Para a extração do RNA foi utilizada a solução de Trizol $^{\Sigma}$ (Invitrogen) seguindo o protocolo recomendado pelo fabricante. Amostras (100 mg) de folhas jovens das plantas mantidas in vitro foram trituradas em almofariz contendo nitrogênio líquido, e o precipitado transferido para tubos eppendorf de $1,5 \mathrm{~mL}$ contendo $1 \mathrm{~mL}$ de tampão Trizol ${ }^{\Sigma}$ (Invitrogen). O homogenizado foi incubado por $5 \mathrm{~min}$. à temperatura ambiente e, em seguida, foram adicionados $0,2 \mathrm{~mL}$ de clorofórmio. A mistura foi submetida à agitação intensa por $15 \mathrm{~min}$. Os tubos foram incubados por $3 \mathrm{~min}$. à temperatura ambiente e, posteriormente, centrifugados a $12.000 \times g$ por $15 \mathrm{~min}$. a $4^{\circ} \mathrm{C}$. O sobrenadante foi cuidadosamente transferido para um tubo novo e foi adicionado $0,5 \mathrm{~mL}$ de isopropanol. As amostras foram incubadas por $10 \mathrm{~min}$. à temperatura ambiente e centrifugadas a $12.000 \times \mathrm{g}$ por $10 \mathrm{~min}$. a $4^{\circ} \mathrm{C}$. Em seguida, o sobrenadante foi removido e o pellet foi lavado com $1 \mathrm{~mL}$ de etanol $75 \%$ e ressuspendido em $50 \mu \mathrm{L}$ de água milliQ autoclavada. 
As amostras foram quantificadas em espectofotômetro (260 nm) e estocadas em freezer $-80^{\circ} \mathrm{C}$.

Eletroforese em gel desnaturante: A separação eletroforética das amostras de RNA total foi conduzida em gel de agarose sob condições desnaturantes e específicas para RNA, seguindo o protocolo descrito por Sambrook et al. (2001). Para a preparação do gel foram utilizados 0,432 $\mathrm{g}$ de agarose fundida em $30 \mathrm{~mL}$ de água milliQ. Foram adicionados $3,0 \mathrm{~mL}$ de tampão Mops 10X (0,2 M de ácido 3-[N-morpholino]propanesulfonico, 0,05 M de acetato de sódio e 0,01 M de EDTA, pH 5,5 - 7,0) e 1,62 mL de formaldeído $37 \%$. As amostras $(2 \mu \mathrm{L})$ foram misturadas em $10 \mu \mathrm{L}$ de tampão de carregamento (720 $\mu \mathrm{L}$ de formamida bidestilada, $160 \mu \mathrm{L}$ de tampão Mops $10 \mathrm{X}$, $260 \mu \mathrm{L}$ de formaldeído $37 \%, 134 \mu \mathrm{L}$ de glicerol $60 \%$ e $80 \mu \mathrm{L}$ de azul de bromofenol saturado) e desnaturadas a $95^{\circ} \mathrm{C}$ por 2 min. e, então, submetidas à eletroforese em gel 1,0\% (p/v) tampão Mops $1 \mathrm{X}$ e visualizadas.

Transcriptase reversa: Em tubos de eppendorff esterilizados $(0,5 \mathrm{~mL})$ foram adicionados 4,0 $\mu \mathrm{L}$ de RNA, 1,0 $\mu \mathrm{L}$ oligodT, 1,0 $\mu \mathrm{L}$ de dNTP (10 mM) e 7,0 $\mu \mathrm{L}$ de água milliQ esterilizada tratada com DEPC 0,01\%. As amostras foram desnaturadas a $65^{\circ} \mathrm{C}$ por $5 \mathrm{~min}$. e colocadas no gelo por $1 \mathrm{~min}$. Em seguida, foram adicionados 4,0 $\mu \mathrm{L}$ de tampão SuperScript III (Invitrogen), 1,0 $\mu \mathrm{L}$ de DTT $(0,1 \mathrm{M}), 1,0 \mu \mathrm{L}$ de transcriptase reversa (Super Script III RT - 200 unidades/ $\mu \mathrm{L}$, Invitrogen) e $1 \mu \mathrm{L}$ de RNAguard e procedeu-se à incubação a $50^{\circ} \mathrm{C}$ por $1 \mathrm{~h}$. $\mathrm{A}$ reação foi inativada a $70^{\circ} \mathrm{C}$ por $15 \mathrm{~min}$. Em cada uma das amostras, foi adicionado $1 \mu \mathrm{L}$ de RNAse (10 mg/mL), e estas foram incubadas por $20 \mathrm{~min}$. a $37^{\circ} \mathrm{C}$, obtendo-se a primeira fita de cDNA para ser amplificada por PCR.

Amplificação da fita de cDNA por PCR: Para amplificação da primeira fita de cDNA foram utilizados $10 \%$ da reação obtida na etapa anterior. Foram utilizados os primers forward 5' ACA TCA GCG CTA AAG CCT TC 3' na posição 487 do gene att A, desenhado por Takahashi (2002) e reverse 5' CCC 
ACT AGT CCA CTT ATT ACC AAA AGA CC 3' na posição 763 do gene att A, que amplificam um fragmento de $\sim 300 \mathrm{pb}$.

Cada reação $(25 \mu \mathrm{L})$ constituiu de $2,0 \mu \mathrm{L}$ da reação de cDNA, $10 \mu \mathrm{L}$ de tampão $(10 \mathrm{X})$ para PCR [200 mM Tris-HCl $(\mathrm{pH} 8,4), 500 \mathrm{mM} \mathrm{KCl}], 3,0 \mathrm{mM}$ $\mathrm{MgCl}_{2}, 50 \mu \mathrm{M}$ de cada dNTP, 1,5 U de Taq polimerase (Invitrogen ${ }^{\mathrm{TM}}$ ), 15,0 pmoles de cada iniciador específico para o gene att $\mathrm{A}$ e 1,3 $\mu \mathrm{L}$ de tampão DMSO. A mistura foi submetida à desnaturação $\left(3 \min\right.$ a $\left.95^{\circ} \mathrm{C}\right)$, seguida de 30 ciclos de amplificação $\left(1 \min\right.$ a $95^{\circ} \mathrm{C} ; 1 \min$ a $50^{\circ} \mathrm{C}$ e $1,0 \min$ a $72^{\circ} \mathrm{C}$ ) e à extensão final $\left(3 \min\right.$ a $\left.72^{\circ} \mathrm{C}\right)$.

Os produtos das reações de PCR foram submetidos à eletroforese em gel de agarose $1,0 \%(p / v)$.

\subsection{Bioensaios}

\subsubsection{Resistência à Xanthomonas axonopodis pv. passiflorae}

Para avaliação da resistência das plantas transgênicas à bacteriose, foram inoculadas folhas das plantas matrizes e das transgênicas com uma solução bacteriana de Xanthomonas axonopodis pv. passiflorae.

Foram usados os isolados bacterianos $89,92,115$, e 117, todos coletados na região de Minas Gerais, os quais foram previamente estudados em nosso Laboratório mostrando-se agressivos em folhas de maracujá amarelo var. FB-100 (Rossin et al., 2004).

Colônias únicas de cada isolado foram multiplicadas em $5 \mathrm{~mL}$ de caldo nutriente (10 g/L de peptona, $3 \mathrm{~g} / \mathrm{L}$ de extrato de carne) por $48 \mathrm{~h}$ a $150 \mathrm{rpm}$. A concentração das células da cultura foi quantificada por espectrofotometria (600 $\mathrm{nm}$ ). Para cada um dos isolados foi preprada uma diluição para obter OD de 
0,3. Em seguida, o inóculo foi preparado misturando-se os diferentes isolados em igual proporção.

Para as inoculações, foram destacadas folhas das plantas matrizes e das transgênicas PCR+, cultivadas in vitro. Com ajuda de um bisturi, previamente imerso em solução bacteriana, foram realizados 3 cortes em cada folha, as quais foram incubadas em placas de Petri $(15 \mathrm{~cm})$ sobre uma lâmina de vidro formando uma câmara úmida, sob temperatura de $25 \pm 2{ }^{\circ} \mathrm{C}$, fotoperíodo de 16 $\mathrm{h}$ e intensidade luminosa de $25 \mu \mathrm{mol} . \mathrm{m}^{-2} \cdot \mathrm{s}^{-1}$. Em cada placa, foram depositadas uma folha matriz e duas folhas da planta transgênica.

\subsubsection{Resistência ao herbicida Finale ${ }^{\circledR}$}

Com o intuito de avaliar a resistência das plantas PCR+ ao herbicida fosfinotricina, pela expressão do transgene bar, foi realizado um segundo bioensaio. Convém lembrar que os experimentos de transformação de explantes hipocotiledonares foram conduzidos na ausência do agente seletivo. Plantas PCR+ para o gene att A não necessariamente expressam outros genes presentes no cassete de expressão.

Discos foliares de $0,7 \mathrm{~cm}$ de diâmetro das plantas matrizes e das plantas $\mathrm{PCR}+$, mantidas in vitro, foram cortados e cultivados em MS solidificado com Ágar $(0,6 \%, \mathrm{p} / \mathrm{v})$ contendo $1,0 \mathrm{mg} / \mathrm{L}$ de $\mathrm{BA}, 5 \%$ de água de coco e $0,3 \mathrm{mg} / \mathrm{L}$ do herbicida fosfinotricina (Finale ${ }^{\circledR}$ ). O experimento foi conduzido em placas de petri $(9 \mathrm{~cm})$, contendo 3 repetições. Cada parcela constituída de 9 discos foliares provenientes de 3 folhas de cada planta PCR+. As placas foram mantidas no escuro por 7 dias e, então, transferidas para $25 \mu \mathrm{mol} \cdot \mathrm{m}^{-2} \cdot \mathrm{s}^{-1} \mathrm{de}$ intensidade luminosa a $25^{\circ} \mathrm{C} \pm 2^{\circ} \mathrm{C}$ e fotoperíodo $16 \mathrm{~h}$. Os explantes foram 
avaliados após 30 dias de cultivo sob microscópio estereoscópico quanto à formação de brotos e à clorose. 


\section{RESULTADOS E DISCUSSÃO}

\subsection{Construção dos vetores pCattA 1302 e pCattA 3300}

O cassete de expressão 35S35SattA35ST (2,1 kb), clonado em pFF19, foi transferido para vetores binários que contêm genes que codificam para agentes seletivos em plantas e/ou genes repórteres (Figura 3), dando origem aos vetores pCattA 1302 e pCattA 3300.

A construção do plasmídeo pCattA 1302 foi feita com o objetivo de realizar transformações via eletroporação de protoplastos, pois este possui o gene hptll, que confere resistência ao antibiótico higromicina, e o gene repórter gfp, que permite monitorar as células transformadas pela visualização da GFP.

Sabendo-se das questões de biossegurança ligadas ao uso de genes que conferem resistência a antibióticos e a importância de se reduzir seqüências adicionais no genoma hospedeiro, o cassete 35S35SattA35ST foi inserido em pCambia 3300, construindo o vetor pCattA 3300 o qual carrega o gene bar que confere resistência ao herbicida fosfinotricina.

O gene att A possui sítios de restrição para a enzima EcoRI (Figura 3). Após o vetor pFFattA ter sido hidrolisado completamente com Hindlll e parcialmente com EcoRI obteve-se um fragmento de 2.100 pb, correspondente ao cassete de expressão, que foi extraído do gel e ligado aos vetores binários, previamente linearizados. Após a transformação, foram obtidas 14 colônias de E. coli DH5- $\alpha$, contendo o inserto pCattA 1302, 22 colonias de E. coli DH5- $\alpha$ e 15 colonias de E. coli JM109 contendo o vetor pCattA 3300. 
A amplificação por PCR, a partir das colônias, confirmou a presença do gene att $A$. Os perfis de restrição obtidos após tratamento dos plasmídeos pCattA 1302 (higromicina R+attA+gfp) e pCattA 3300 (fosfinotricina R+attA) com EcoRI, Xhol e Hindlll (Figura 3), forneceram evidências adicionais da presença do cassette de expressão nos vetores pCattA 1302 e pCattA 3300.

$O$ sequenciamento dos insertos dos plasmídeos construídos seguido de alinhamento com o cDNA do gene att A (765 pb) (GenBank NCBI U46130) (Figura 4) mostrou que as clonagens foram adequadas para subsequente expressão.

Os vetores pCattA 1302 e pCattA 3300 estão apresentados na Figura 5. 


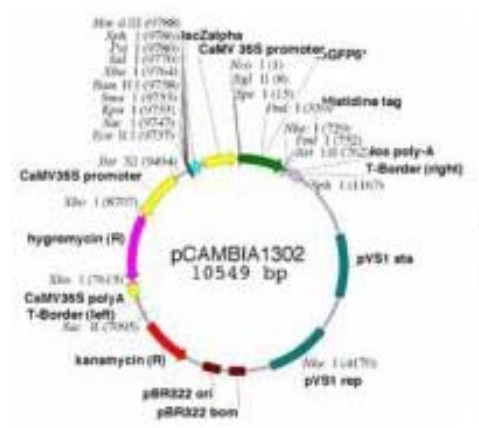

A

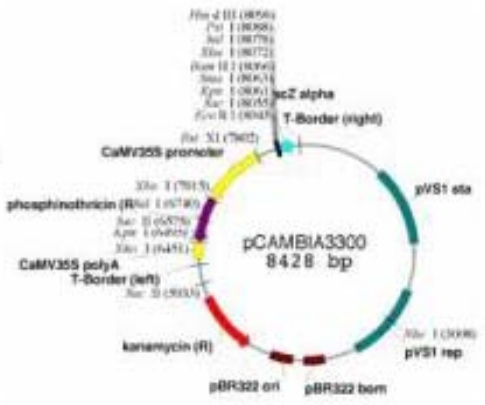

B

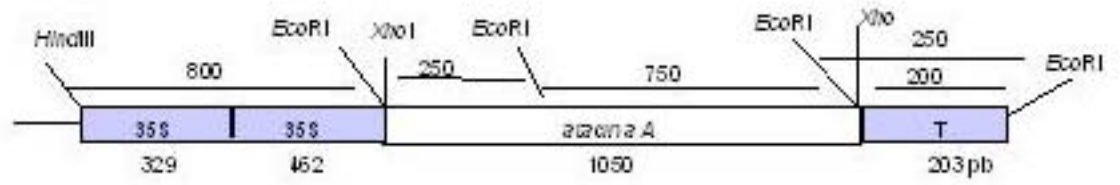

C
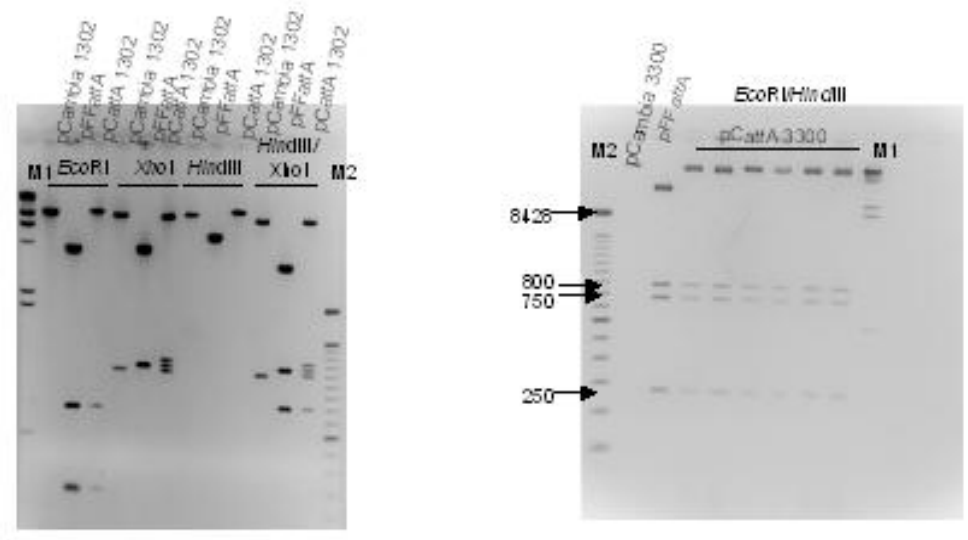

D

$E$

Figura 3 - Construção dos vetores pCattA 1302 e pCattA 3300. A) Vetor pCambia 1302. B) Vetor pCambia 3300. C) Cassete de expressão 35S35SattAT com os sítios de restrição para as enzimas EcoRI e Xhol. D) Caracterização do vetor pCattA 1302 digerido com as enzimas EcoRI, Xhol Hindlll e HindlII/Xhol e E) Caracterização do vetor pCattA 3300 digerido com as enzimas EcoRI/HindlII. M marcadores de peso molecular: $\lambda$ HindlII (1) e Ladder 100 pb (2) 


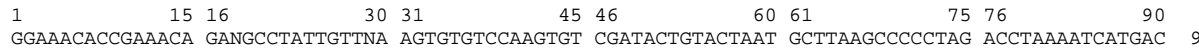
1 pCat1302 GGAAACACCGAACA GANGCCTATTGTTNA AGTGTGTCCAAGTGT CGATACTGTACTAAT GCTTAAGCCCCCTAG ACCTAAAATCATGAC 90

3 AtacinaR - .....
105106
120121
135136
150151
$165166 \quad 180$

1 pcat 1302 CTAAAACCAAAATCC TTAATCTTTAAAATA ACTATCTTCATAAAA TGTTTATGTTTATGT ATGATTCCCAAAGAA TATACGAGTTGTGTA 180 1 pCat1302 CTAAAACCAAAATCC TTAATCTTTAAAATA ACTATCTTCATAAAA TGTTTATGTTTATGT ATGATTCCCAAAGAA TATACGAGTTGTGTA 180

2 PCa 33002 CTAAAACCAAATCC TTAATCTTTAAAATA A

181

195196

210211

225226

240241

255256

270

1 pCat1302 CTCGCTTTGgGATAT CCTTGGGATTAAGG AATAGACCCTTGATG AGTGTGTAATAATAC CTCTTTGAGCTCGAA CGTACGgACGTCCAG 270 pCat 3300 CTCGCTTTGGGATAT CCTTGGGATTAAGGG AATAGACCCTTGATG AGTGTGTAATAATAC CTCTTTGAGCTCGAA CGTACGGACGTCCAG 268

3 AtacinaR

271

285286

300301

315316

345346

360

1 pCat 1302 CTGAGATCTCCTAGG GGCCCATGGCCCGGG GGGGGAGCACGGCGA GCACGGCTTAAGCCT GCTCGCCGTGCTCCA CTTTATTAAAATAAG 360 2 pCat 3300 CTGAGATNTCCTAGG GGCCCATGGCCCGGG GGGGGAGCACGGCGA GCACGGCTTAAGCCT GCTCGCCGTGCTCCA CTTTATTAAAATAAG 358
361
375376
390391
405406
420421
435436
450

1 pCat 1302 TTATTTATTTATGAC NTTACTTGAATGTTT AACCTGTGTTAAACA AAGCCGACATAGTAA TAGTATGAAATNAAT TGTCTCAGCCANCGA 450 pCat 3300 TTATTTATTTATGAC TTTACTTGAATGTTT AACCTGTGTTAAACA AAGCCGACATAGTAA TAATATGAAATCAAT TGTCTCAGCCAACGA 448 3 ATOCIIR R -

$465466 \quad 480481$

495496

510511

525526

540

1 pCat 1302 TGGATATTTATAAAG NCTTATTAGAATTAG ATNAAATCTTGTCTC TTTCGTCTTTTTTTG ACCAGGAA-GAAGAT GGTGAATAATGGTTT 539 2 pCat 3300 TGGATATTTATAAAG TCTTATTAGAATTAG ATCAAATCTTCTCTC TTTCGNCTTTTTTTG ACCAGGAAAGAAGAT GGTGAATAATGGTTT 538 3 AtacinaR …

541

570571

585586

600601

615616

630

1 pCat1302 TCTGGCCGNTTTTCA TTCAGGCTTTCAAAC CAAGGGGTTAATGAG AATNNGTGACCACAC AGTTTTGAAAGAATT GTNGGTCNGCAA-CN 628 2 pCat 3300 TCTGGCCGATTTTCA TTCAGGCTT-CAAAC CAAGGG-TTAATGAG AAATGGGACCACAC AGTTTG - -AAGAATT -TCGGTCCTCAAACT 623 3 AtacinaR TCTGGCCGATTTTCA TTCAGGCTT-CAAAC CAAGGG-TTAATGAG AATTTGTGACCACAC AGTTTG--AAGAATT -TCGGTCG-CAA-CT 102

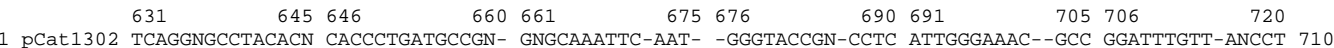
1 pCat1302 TCAGGNGCCTACACN CACCCTGATGCCGN - GNGCAAATTC-AAT- -GGGTACCGN-CCTC ATTGGGAAAC--GCC GGATTTGTT-ANCCT 710 \begin{tabular}{l} 
D \\
pCat 3300 TCAGGTGCCTACACC -ACCCTGATGNCCTT GTGCAAATTCCAANT GGGGTACCCCACCTC ANTCAGAAANCGGCC AGATTTNTTTACCCT 712 \\
\hline
\end{tabular}

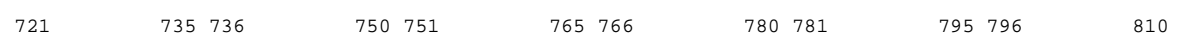
1 pCat1302 GNNCCAAACGGGNC GGNTCTTTAACGCGG NTGNN-ACNAAGNGC NNGGTATATNNAGGC TTAGGG--GGTGGGN TNCNC--ATAAGTGG 795 TATNNAGGC TTAGGG--GGTGGGN TNCNC--ATAAGTGG 795

811

825826

840841

855856

870871

885886

900

1 pCat 1302 CNNACCCCANTGTNA ACNCCC--TTNAAGT NA--GGNACCANGGA NCCCCANNGTTTNCC GNAANGTG-GGGGAG CTGANGNGGGTCAGN 880 pCat 3300 NANACCCCATGNNAA AAACCCCTTTTCAGN TCCC - -TNNCNAANA ACCNANCTGNNTTNC CCNAGATTTGGNGNN CTTNCNAGGTACCCN 892 3 AtacinaR CAA--CCCAT-GTAA A--CCC - - -TTCAGT CC - - GTA- -CAAGA ACC - -ACTGCTT- - - CCGAAATC - -GCGAC - - TACA - -GTAC - - 317

901

915916

930931

945946

960961

975976

990

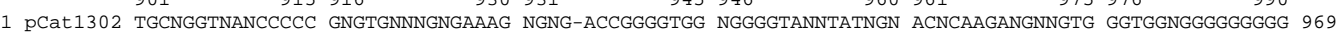
2 pCat3300 AACCGNAAACCACCC - - - TTTTTTNTAAANT TGAGGANCCGGNCCA AGGGGNNAGNTTNGG AC - -NAGCCGGCTT- - . - - TAGGGGNNCN 971

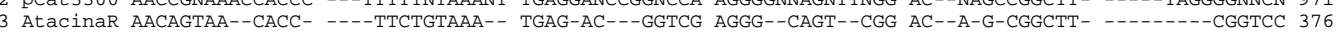

Figura 4 - Alinhamento das sequências amplificadas a partir dos vetores pCattA1302 e pCattA 3300: cDNA do gene attA (GenBank NCBI U46130) 
10351036

10501051

10651066

1080

1 pCat1302 NNGTTGAGGNTAA-A NATNGGTGGGTNGA CNANGCAGGANGA-- GATGGTATGGNGTNT GGAGGTNTGTGATGG CGTGAGAGNANGGNA 1056 pCat3300 TTGACCCGCCAAATA GTTTTTNGGGGNCGG CCNCCCCCNCCNCCC GGTGGGAGGGTTNCN GGAAAAGNGTTCGAA GGNAAGANTAANNTT 1061

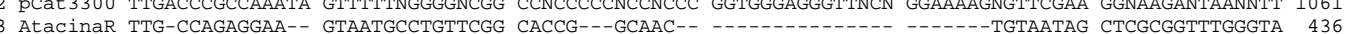

1081 10951096 11101111 11251126 11401141 11551156 1170

1 pCat1302 TGGGGCNATNGGNAT NNTGATTACNA--AN NTNNNGGAGATGTGA NGTGNANAGGCATNG NCGANTTGGGNGCAC GTGGNTANNAGAAAN 1144 2 pCat3300 TTGTAGAAGAANGNA GCNG -TGNTGA- -AN TTCNAGGGG-TGTCC NTTGCTCCNACA - - - ANGNAAAGGGAAC - C N - . - - TCCCCTTAAT 1139

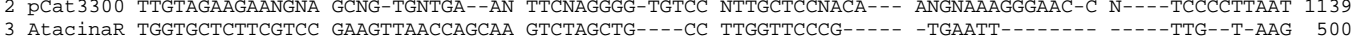
1171 11851186 12001201 12151216 12301231 12451246 1260

1 pCat1302 AGATGAGNAAAGGGN GGAGANCGANGGGNG NGANGTGNNNGGNGA GNGGAGGNAANGNTN AGTCNANNGATNGCT AGAGNATGNNNCAGC 1234 2 pcat3300 ATTAGGGGGAGGGT TCTTTGCGAANGGAN TANGGGGATTGG - - - -TGGNT-CAATCCCC TTTACNGNCAGGGGG AGA-TATTCACCATC 1224 2 pCat3300 ATTAGGGGGAAGGT TCTTTGCGAANGGAN TANGGGGGATTGG --
3 AtacinaR A--AGGNT-CAATCCCC TTTACNGNCAGGGGG AGA-TATTCACCATC 1224

1261

12751276

12901291

13051306

13201321

13351336

1350

1 pCat1302 TNANGTGNCCAGAAN TGGNGGGCNGCGAAA NGGNNGGGNAGNNAA GNGTGGGTANNACAN GGNAANAGG-TNTNG GGATNGNNAGGCATG 1323 2 pCat3300 CGAA---TCCCACNT TGNNT - - TTGGGANA ACGGGGGGT-GGGNA ACGTNNTTNTTT- - T TNCACGATGCTCCCT CGGTGGGTGGG - -GG 1304

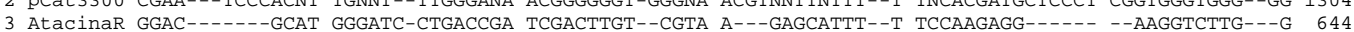

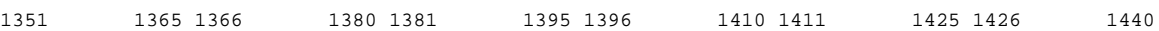

1 pCat1302 NAAANTNGATTTANG GAGNGNTAACGAGG CGAGAGAAAGCNGAN CNGNANGAGGTNGAN ANNTCNTNCNGANAA GGGNAGGGGAGNANG 1413 1 pCat1302 NAAANTNGATTTANG GAGNGNTAACGAGG CGAGAGAAAGCNGAN CNGNANGAGGTNGAN ANNTCNTNCNGANAA GGGNAGGGGAGNANG 1413

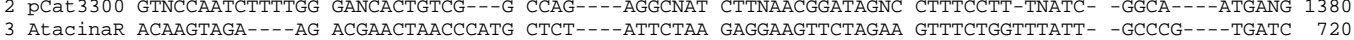

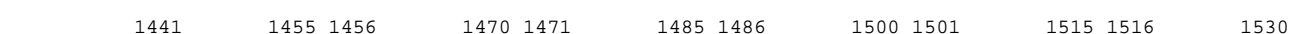

1 pCat1302 NANTNANGTAGNNGN NNGCNAANGANGTNG ANATGGANTTAGNGN NNGCNANGANATANN GCAAGNTNNGCATNN NGCGAGNGANANGCN 1503 1 pCat1302 NANTNANGTAGNNGN NNGCNAANGANGTNG ANATGGANTTAGNGN NNGCNANGANATANN GCAAGNTNNGCATNN NGCGAGNGANANGCN 1503 2 pCat3300 GCATTTTGTAGGTGC CCNCCNTCCTT-TTN TACTGTCCTT--TGG ATGAAGTGACAGATA GC- TTGGGCAATG 3 AtacinaR GCCTATGGT--GTTC CTGGTTAGGT-TTT AGTTAACATC-CAC TTGTA-

\section{$\begin{array}{llllllllll}1531 & 15451546 & 1560 & 1561 & 1575 & 1576 & 15901591 & 1605 & 1606 & 1620\end{array}$}

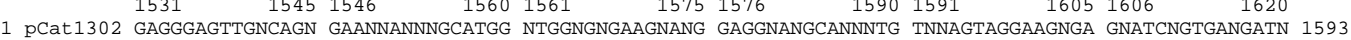
2 pCat3300 GAGGGAGGTTTCC -C GATATTACCCT-..- TTGTTGAAAAGTCTC AA-- TAGCCCTTTGG TCTTCTG---AGNCT GTATCTTTGATATTC 1535 3 AtacinaR -................

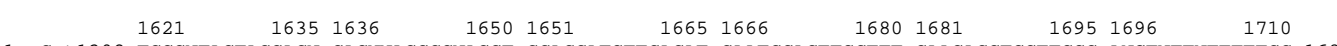
1 pCat1302 TGGGNTAGTAGGACN GAGNNAGGGGNAGCT CCACCATGTTCACAT CAATCCACTTGCTTT GAAGACGTGGTTGGG ANGTNTTNTTTTTCC 1683 pCat3300 TTGGA--GTAGANGA GAGTGTCGTGC---T CCACCATGTTCACAT CAATCCACTTGCTTT GAAGACGTGGTTGGA ACGTCTTCTTTTTCC 1620 3 AtacinaR _ . $\ldots \ldots \ldots \ldots$

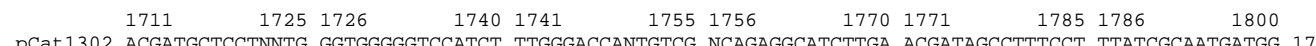
1 pCat1302 ACGATGCTCCTNNTG GGTGGGGGTCCATCT TTGGGACCANTGTCG NCAGAGGCATCTTGA ACGATAGCCTTTCCT TTATCGCAATGATGG 1773 pCat3300 ACGATGCTCCTCGTG GGTGGGGGTCCATCT TTGGGACCACTGTCG GCAGAGGCATCTTGA ACGATAGCCTTTCCT TTATCGCAATGATGG 1710 3 AtacinaR

$\begin{array}{llllllllll}1801 & 1815 & 1816 & 1830 & 1831 & 1845 & 1846 & 18601861 & 1875 & 1876\end{array}$ 1 pCat1302 CANTTGTAGNTGCCA CCTTCCTTTTCTACT GTCCTTTTGATGAAG TGACAGATANCTGGN CAATGGAATCCGAGG AGGTTTCCCGATATT 1863 2 pCat3300 CATTTGTAGGTGCCA CCTTCCTTTTNTACT GTCCTTTTGATGAAG TGACAGATAGCTGGG CAATGGAATCCGAGG AGGTTTCCCGATATT 1800 3 Atacinar $\ldots$

$\begin{array}{llllllllll}1891 & 19051906 & 19201921 & 19351936 & 19501951 & 19651966 & 1980\end{array}$ 1 pCat 1302 ACCCTTTGTTNCAAA GTCTCAATAGCCCTN TGGTCTTGTGAGGCG GTATCTTTGATANTC TNAGAGTAGACGAGA GTGTCGTGCTCCACC 1953 2 pCat3300 ACCCTTTGTTGAAA GTCTCAATAGCCCTT TGGTCTTCTGAGACT GTATCTTTGATATTC TTGGAGTAGACGAGA GTGTCGTGCTCCACC 1890 3 AtacinaR $\ldots$

1981 1 pCat1302 ATGTTGGCAAGCTTG GCACTGGCCGTCGTT TTACAACGTGATGGA A-GGGAAAANCCTGG CGAGCCCAAGTTAAN CGCTTGCNTCTNC 2040 2 pCat3300 ATGTTGGCAAGCNT - G-ANTGGCCGTCGTT TTACAACGTNGTGNN ATGGGAAAACCCTGG CGNACCCAAGCTAAT CGCCTGCNTANNC 1978 3 AtacinaR -

\section{Figura 4 - Alinhamento das sequências amplificadas a partir dos vetores pCattA1302 e pCattA 3300: cDNA do gene attA (GenBank NCBI U46130)}


A

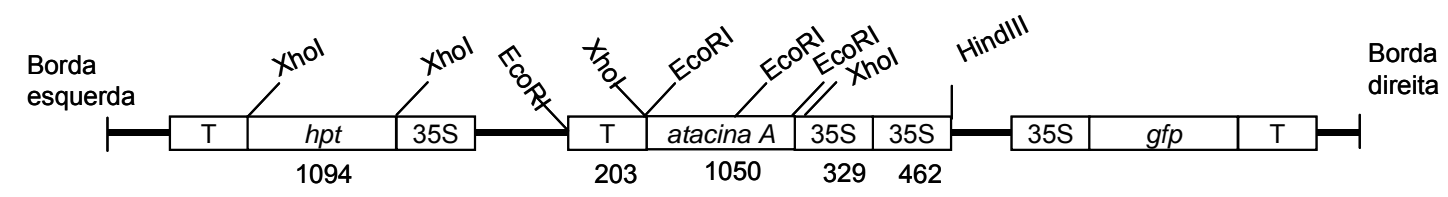

B

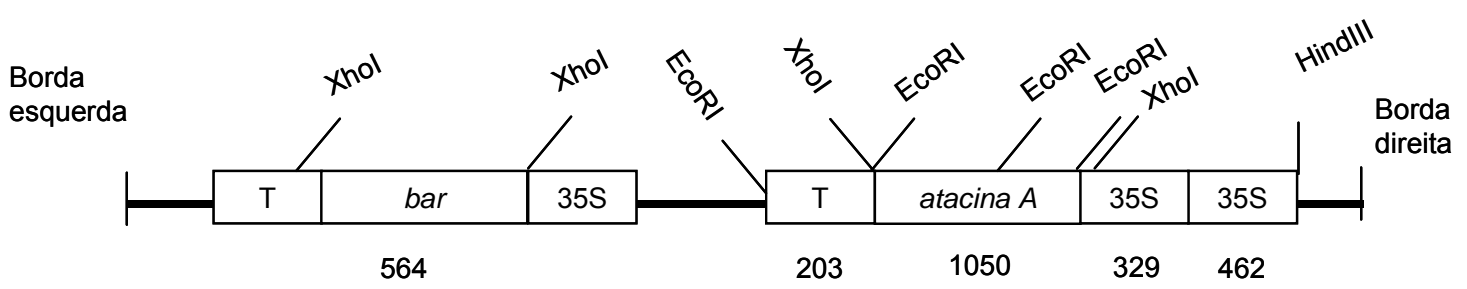

Figura 5 - Representação dos vetores pCattA 1302 (12560 pb) (A) e pCattA3300 (10472 pb) (B). Os números representam o tamanho das seqüências em pb

\subsection{Direcionamento da atacina $\mathrm{A}$}

\subsubsection{Construção dos vetores pSPattA 1303 e pattA 1303}

A proteína atacina A possui um peptídeo sinal de 54 pb que a direciona para a hemolinfa dos insetos. Quando a seqüência de proteínas depositada no GenBank foi analisada pelo programa SignalP 3.0 (http://www.cbs.dtu.dk/services/TargetP/), observou-se que há 95,4\% de chance (confiabilidade) de que esta seja direcionada para o meio extracelular (apoplasto).

Fragmentos correspondentes ao gene att A com o peptídeos sinal (SP) (765 pb) e sem o peptídeo sinal (711 pb) foram inseridos no vetor pCambia 1303, na região entre o promotor $35 S$ e o uidA formando o cassete de 
expressão 35Satt:uidA:gfpNos. Os vetores foram chamados de pSPattA 1303 (13.127 pb) e pattA 1303 (13.073 pb) (Figura 6).

Após a transformação de células competentes de E. coli (JM109) foram obtidas quatro e cinco colônias contendo, supostamente, o vetor pPSattA 1303 e o vetor pattA 1303, respectivamente. A presença do inserto nestas colônias foi confirmada por PCR, utilizando-se primers (Tabela 3) que amplificaram um fragmentos de 765 pb (SPattA) e 711 pb (pattA).

A hidrólise com Ncol e Spel liberou o gene att A do plasmídeo (Figura 7). Estas restrições comprovaram, novamente, que as clonagens foram adequadas.

As análises de seqüências de nucleotídeos e de aminoácidos preditos (item 3.2.1) das regiões de fusão entre o gene att $A$ ao uidA mostrou que as ligações ocorreram em fase de leitura correta (Figura 8). 


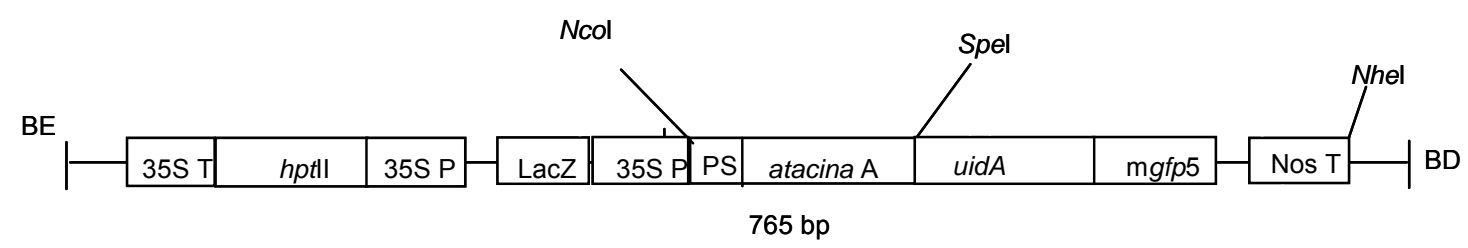

C

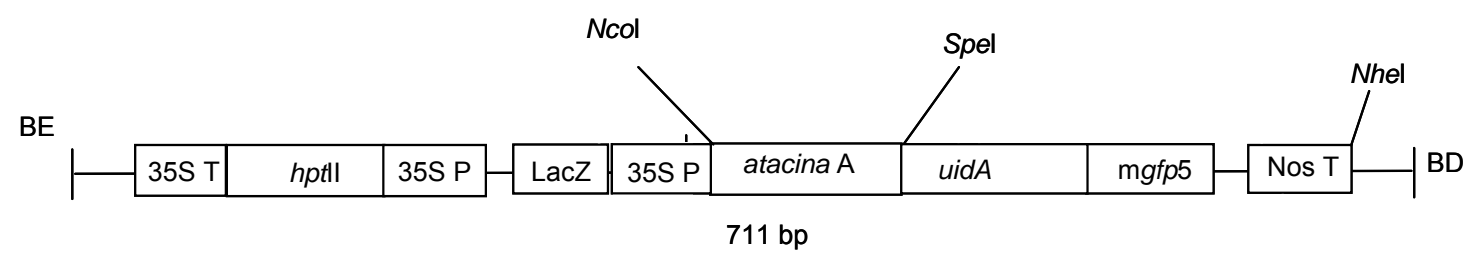

Figura 6 - Vetores pSPattA 1303 e pattA 1303. A) Amplificação via PCR do gene att $A$ com e sem o peptídeo sinal a partir de primers desenhados de modo a conter os sítios de Ncol e Spel nas extremidades; B) Representação do vetor pPSattA 1303 (13.081 pb) e C) Representação do vetor pattA 1303 (13.027 pb) 


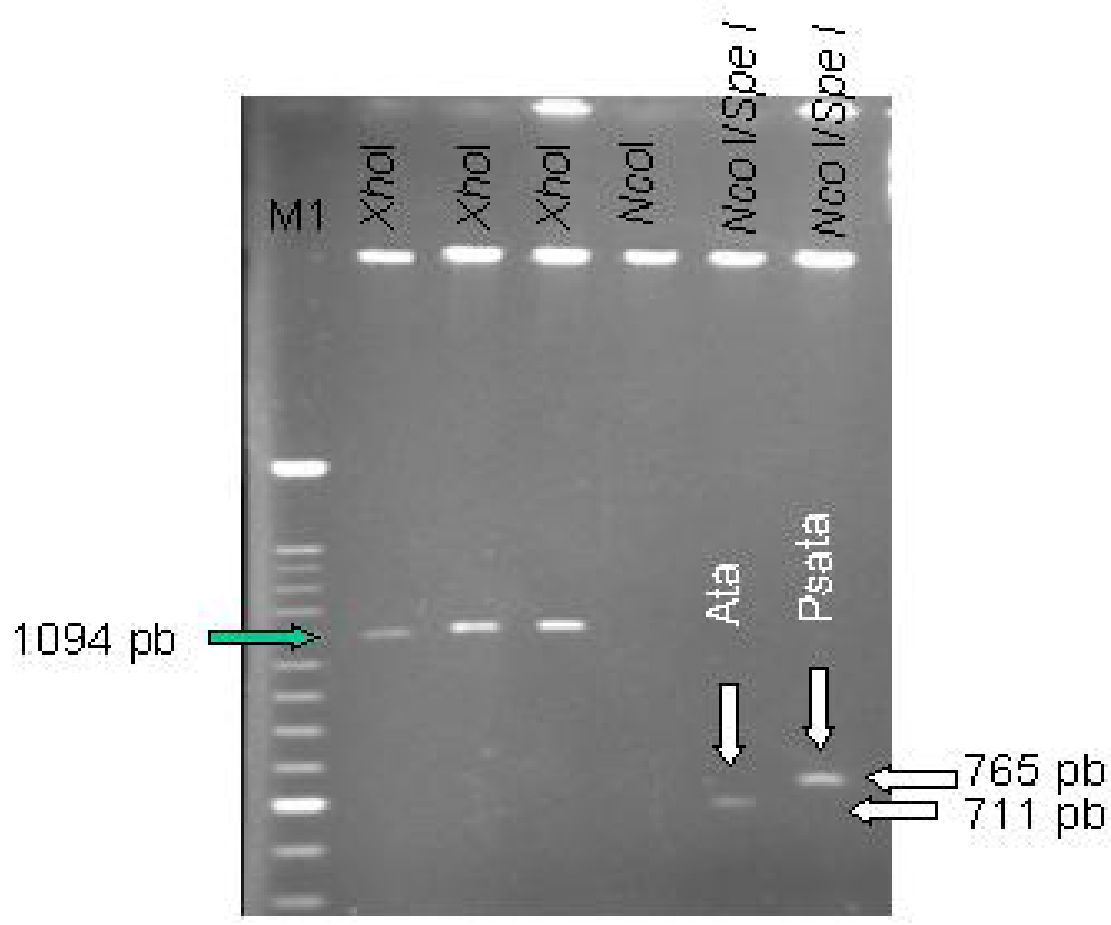

Figura 7 - Clivagem dos vetores pPSattA1303 e pattA 1303 com enzimas Xhol, Ncol e Ncol/Spel (M1 - marcador de peso molecular Ladder 100 pb) 
A

ATGGAAATGTNCACCTACAAATTGATTNTGGGATTGGTCCTTGTGGNATCCGCTAGTGCCCGTTATTTGGTCTTTGAAGATCTTGAAGGAGAATCTTATC 100 TCGTACCCAATCAAGCAGAAGATGAACAGGTTCTGGAAGGAGAACCTTTTTACGAGAATGCTGTTCAGCTAGCCAGTCCTAGGGTACGCAGGCAAGCGCA 200

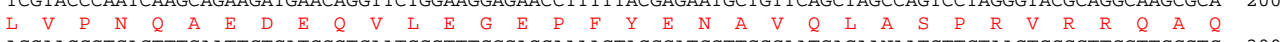
AGGAAGCGTCACTTTGAATTCTGATGGGTCAATGGGTTTGGGAGCAAAAGTACCCATCGTTGGCAATGAGAANAATGTTCTAAGTGCCCTTGGTTCCGTC 300

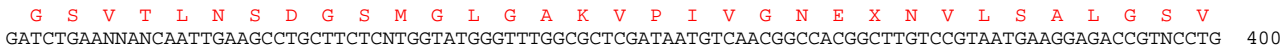

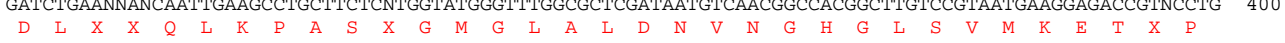
GCTTCGNCGACANGCTGACGGGNGCTGGCAGANTAAATGTCTTTCACAATGACAACCATGACATCAGCGCTAAANCCTTCNTCANCAAGAACATGCCTGA 500 CTTCCCAAATGTACCCAACTTTAATACCGTCGGTGGCGGAGTCGACTATATGTACAAGAACAAAGTAGGCGCATCTCTTGGCATGGA CTTCCCAAATGTACCCAACTTTAATACCGTCGGTGGCGGAGTCGACTATATGTACAAGAACAAAGTAGGCGCATCTCTCGGCATGGCAAACACTCCATTC 600 TTAGACCGCNAAGACTACTCAGCCATGGGTAACTTAAACGTGTTCCGTAGTCCCACCACATCCGTGGACTTCAACGCTGGCTTTAANAAGTTTGACACAC 700

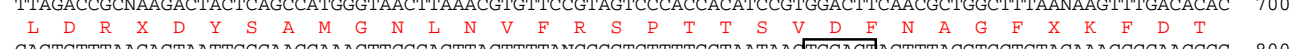
CAGTGTTTAAGAGTAATTGGGAACCAAACTTCGGACTTACTTTTANCCGGTCTTTTGGTAATAAGTGGACTAGTTTACGTCCTGTACAAACCCCAACCCG 800 TGAAATCAAAAAACTCGACGGCCTGTGGGCATTCANTCTGGATCGCGAAAACTGTGGAATTGATCAGCGTTGGTGGGAAAGCGCNTTACAANAAAGCCGG 900

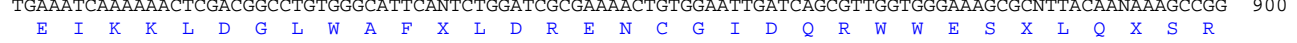
GCAATTGCTGTGCCAGNCAGTTTTNACNGATCAGTTCGCCGATGCAGATATTCNTAATTATGCNGGCAACNTCTGGTTTCAGCGCGAAGTCTTTATACCG 1000 AAAGGTTGGGCAGGCCACCGTATCNTGCNGCGTTTCGATGCGGNCCCTCATTNCNGGAAAGTGTGGGTCNNTCATCCANGAANTGATGGANCCATCATGG 1100

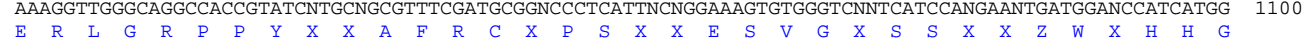
GCNNGCTATACNGCCNCTTTGAANCCGATTGTNACNGCCCCCCATGTNANTTGGCCCNGGGAAANANTTGTNANNTANCACCCGGTNTTGCNGNTGAACN 1200

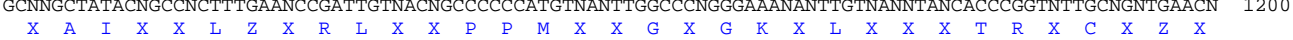
CNNGCANCTTGACNNTTGGCCAAACNNATCCCCNCCCGCCCNAATTNGNTGNATTCCNCCGCACGATNNCACNNGCCANNCAAAACCCAGCCACNACCTC 1300

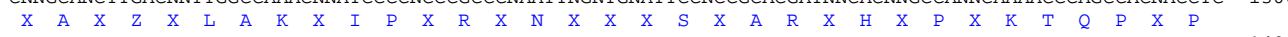
ACCCNGGATTGCCCTTNAAACTACTCCCGGGACANCCCNCCCGCCACCCGTTAAAATGNCCTNNCANCCACCNGCCCTACCANNCCTGGNNGTNCGCNCA 1400

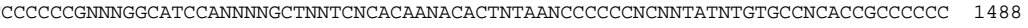

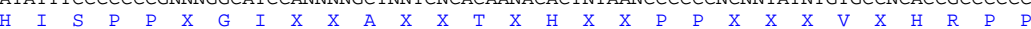

$\mathrm{B}$

\begin{abstract}
ATGGCCCGTTATTTGGTCTNTGAAGATCTTGAAGGAGAATCTTATCTCGTACCCAATCAAGCAGAAGATGAACAGGTTCTGGAAGGAGAACCTTTTTACG 100

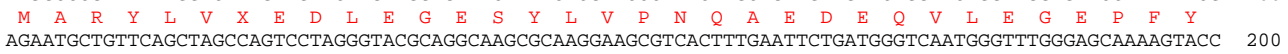

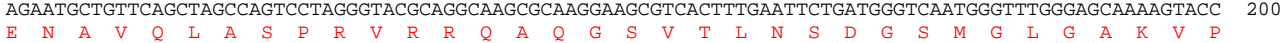

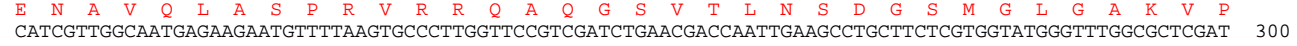

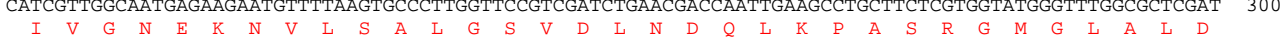
AATGTCAACGGCCACGGCTTGTCCGTAATGAAGGAGACCGTTCCTGGCTTCGGCGACAGGCTGACGGGAGCTGGCAGAGTAAATGTCTTCCACAATGACA 400 $\begin{array}{lllllllllll} & & & \end{array}$ ACCATGACATCAGCGCTAAAGCCTTCGTCACCAAGAACATGCCTGACTTCCCAAATGTACCCAACTTTAATACCGTCGGTGGCGGAGTCGACTATATGTA 500 CAAGAACAAAGTAGGCGCATCTCTCGGCATGGCAAACACTCCATTCTTAGACCGCAAAGACTACTCAGCCATGGGTAACTTAAACGTGTTCCGTAGTCCC 600

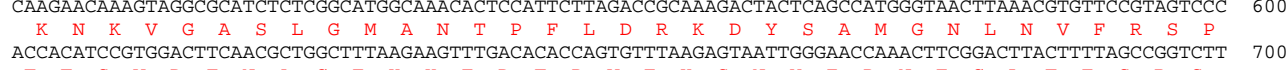

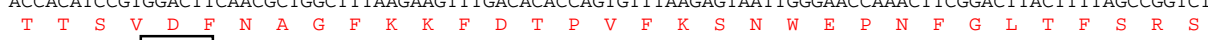
TTGGTAATAAGTGGACTAGTTTACGTCCTGTAGAAACCCCAACCCGTGAAATCAAAAACTCGACGGCCTGTGGGCATTCAGTCTGGATCGCGAAAACTG 800

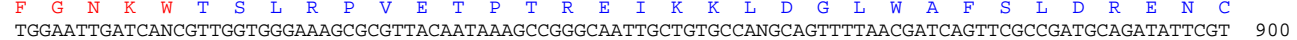
TGGATTGATCANCGTTGGTGGGAAAGCGCGTTACAATAAAGCCGGGCAATTGCTGTGCCANGCAGTTTTAACGATCAGTTCGCCGATGCAGATATTCGT 900 \begin{tabular}{llllllllllllllllllllllllllllllll} 
& $G$ & $I$ & $D$ & $X$ & $R$ & $W$ & $W$ & $E$ & $S$ & $A$ & $L$ & $Q$ & $Z$ & $S$ & $R$ & $A$ & $I$ & $A$ & $V$ & $P$ & $X$ & $S$ & $F$ & $N$ & $D$ & $Q$ & $F$ & $A$ & $D$ & $A$ & $D$ \\
\hline
\end{tabular} AATTATGCGGGCAACGTCTGGTATCAGCGCGAAGTCTTTATACCGAAAGTTGGGCAGGCCANCGTATCGTGCTGCGTTTCGATGCGGTCACTCATTACG 1000 $\begin{array}{lllllll} & \end{array}$ GCAAAGCTGTGGGNCCNTAATCAGGAAGGTGATGGGAGGCATTCCGGGCCGGGTATTACNCCATNTTTGAANCCCGNATGTCACGCCGTATNGTTAATTT 1100 NCCGGGAAAAANTGTTANGNCTTCNCCGGTTTTGGTTGTTGANCNACNNTACCTGAANCCTNGGCTNNACCTATCCCCCCCCNCGGCAATTNGGNNGNTT 1200

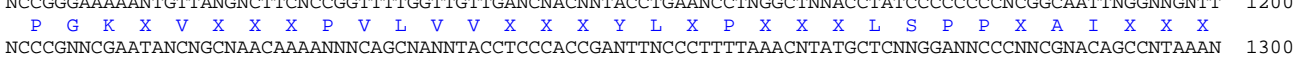
NCCCGNNCGAATANCNGCNAACAAAANNNCAGCNANNTACCTCCCACCGANTTNCCCTTTTAAACNTATGCTCNNGGANNCCCNNCGNACAGCCNTAAAN 1300

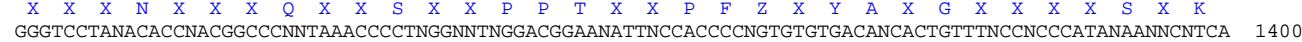

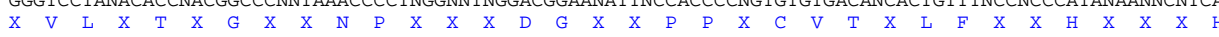

CCNCCTCCCCTNTTNTGGTNAACTCGGGTCCCCNGGNTNN 1441
\end{abstract}

Figura 8 - Sequências de nucleotídeos e de aminoácidos das construções pSPattA 1303 (A) e pattA 1303 (B) na região 5' do gene att A e sua ligação com uidA presente em pCambia 1303: Linha simples $=$ peptídeo sinal. Retângulo = região de fusão dos genes att A e uidA; os códons de inicio da tradução estão em negrito. Os aminoácidos da proteína atacina A estão em vermelho e os da ß-glucoronidase estão em azul. Os aminoácidos da região de fusão estão em preto 


\subsubsection{Transformação por biobalística das células da epiderme de cebola}

A escolha de um tecido sem plastos verdes, como a epiderme dos bulbos de cebola, facilitou, de fato, a visualização da expressão dos genes uidA e gfp. Este sistema modelo mostrou que o direcionamento da proteína atacina $A$ se dá para o apoplasto das células vegetais.

Células transformadas com o plasmídeo pCambia 1303 (controle) apresentaram a proteína GFP e cristais de GUS no citoplasma (Figura 9), assim como as células transformadas com a construção sem o peptídeo sinal (pattA 1303) (Figura 10). Por outro lado, as células bombardeadas com a construção contendo o peptídeo sinal (pSPattA 1303) mostraram as proteínas no apoplasto, ou seja, que elas foram exportadas (Figura 11). Confirmando, o direcionamento da atacina A se dá para o apoplasto de plantas, analogamente ao que ocorre em insetos, nos quais a proteína bactericida encontra-se na hemolinfa.

Os resultados indicam que o sistema de transformação genética aqui proposto - baseado na atacina A - é indicado para se obter plantas de maracujá resistentes à Xanthomonas, visto que a bactéria se multiplica no apoplasto e daí se dissemina para todos os tecidos da planta.

Ko et al. (2000) observaram que plantas de maçã transformadas com o gene att $\mathrm{E}$, fusionado ao peptídeo sinal da proteína $1 \mathrm{~b}$ de tabaco, relacionada à patógenos, que direciona a proteína para o apoplasto, apresentaram menos sintomas da doença provocada por Erwinia amylovora do que aquelas que possuíam as construções sem o peptídeo sinal. Da mesma forma, os autores concluíram que a atacina secretada é mais eficiente na redução da infecção bacteriana. 

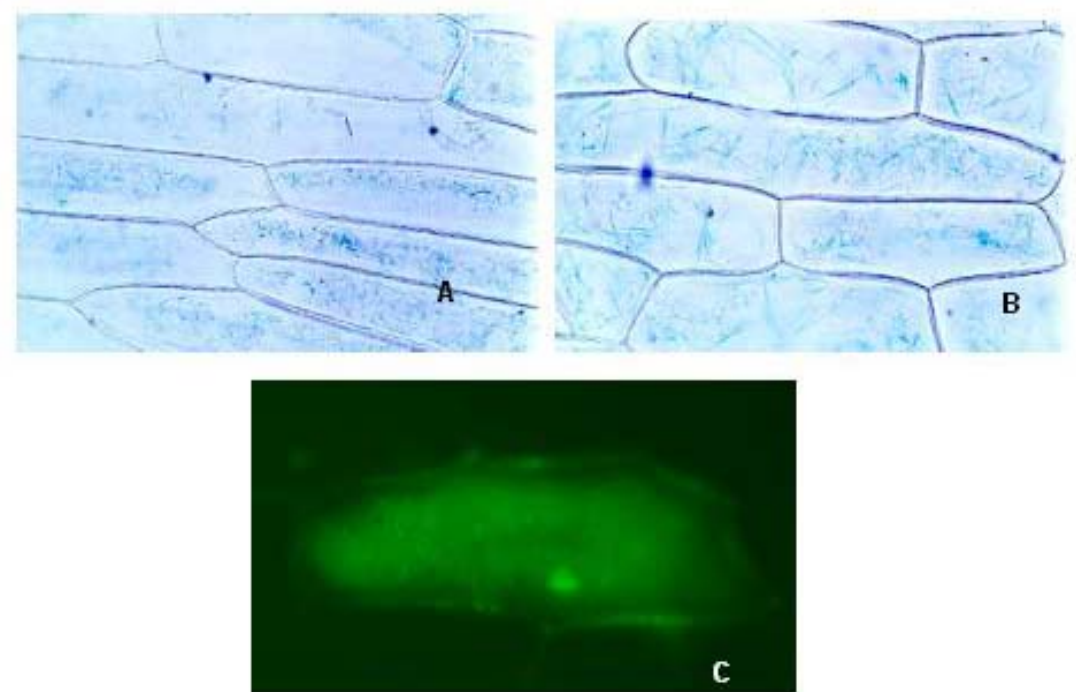

Figura 9 - Ensaio controle: expressão dos genes repórteres no citoplasma das células plasmolisadas de cebola, após bombardeamento com pCambia 1303. Expressão do uidA visualizada sob luz branca (A, B) e do gfp vizualizada sob luz UV (C) (100 X)
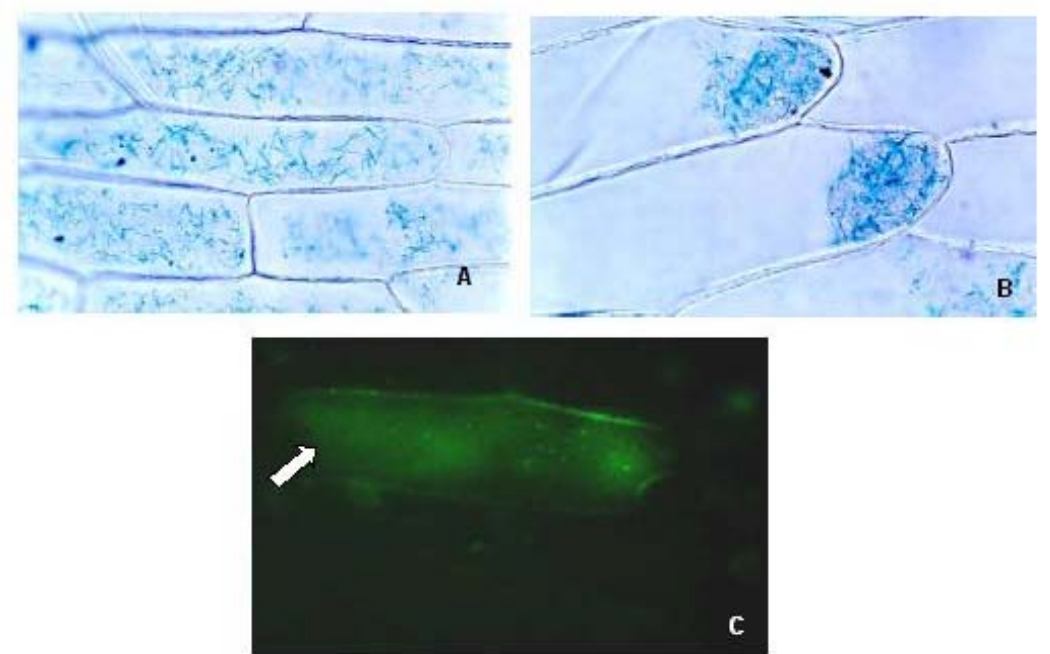

Figura 10 - Expressão dos genes repórteres no citoplasma das células plasmolisadas de cebola, após bombardeamento com pattA 1303. Expressão de uidA visualizada sob luz branca (A, B) e do gfp vizualizada sob luz UV (C) (100 X) 

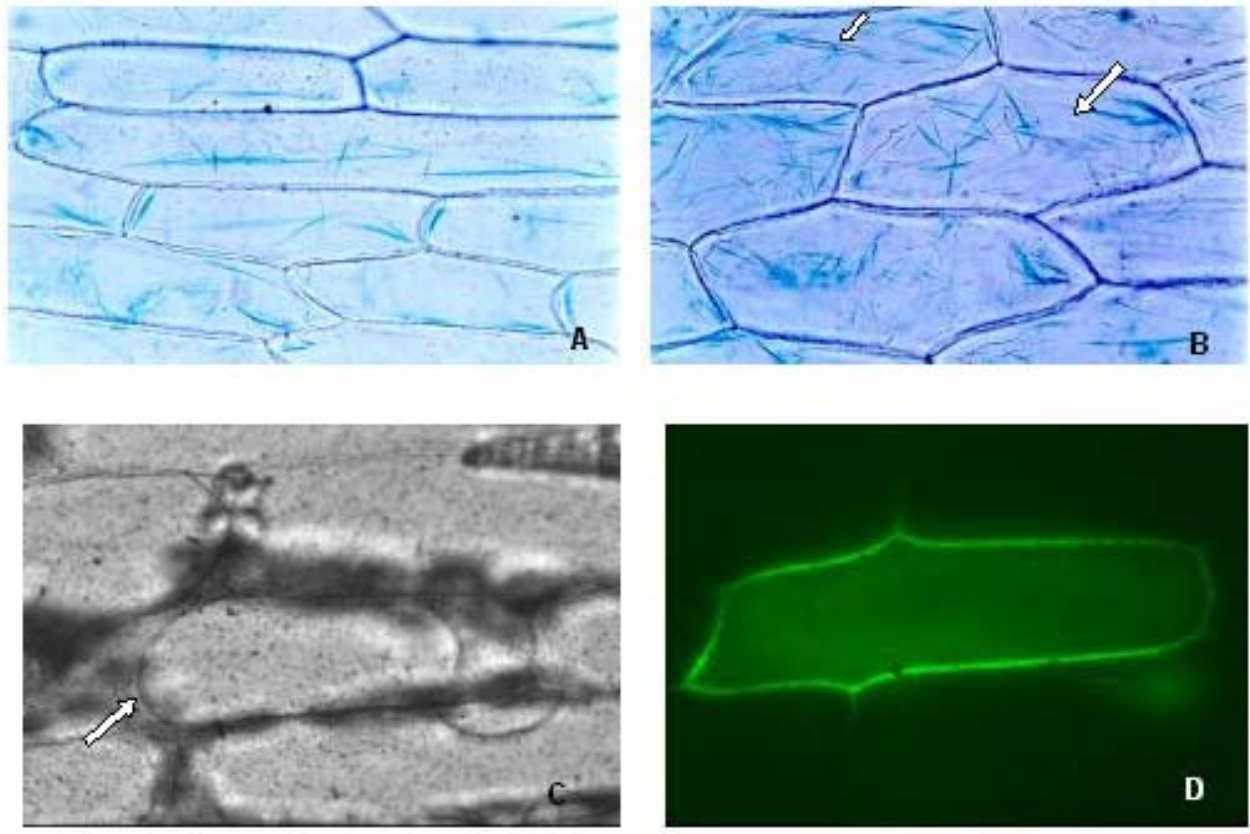

Figura 11 - Expressão dos genes repórteres no apoplasto das células plasmolisadas de cebola, após bombardeamento com pPSattA 1303. Expressão do gene uidA (A,B - $100 \mathrm{X})$, Células visualizadas sob contraste de fase (C - 100X), Expressão do gene gfp vizualizada sob luz UV (D, 100 X) (Setas indicam a membrana plasmática)

\subsection{Cultura in vitro}

\subsubsection{Germinação in vitro de sementes de maracujá amarelo}

A taxa de germinação foi da ordem de 93\%, após 10 dias da inoculação das sementes in vitro. Os tratamentos de desinfestação e esterilização foram eficazes, não ocorrendo contaminação. Foi obtida uma população de 50 indivíduos.

Essa população foi subcultivada mensalmente por estaquia in vitro visando servir como fonte de tecido vegetal para otimização dos protocolos de isolamento e cultura de protoplastos, regeneração de plantas a partir de 
explantes foliares, hipocotiledonares e cotiledonares e, posteriormente, para transformação genética.

\subsubsection{Eletroporação de protoplastos}

\subsubsection{Isolamento, cultura e regeneração plantas a partir de protoplastos de maracujá amarelo}

Protoplastos de maracujá têm sido isolados a partir de diversos explantes, foliares, cotiledonares, suspensões celulares, pétalas e micrósporos, mas a regeneração de plantas foi observada apenas a partir de tecidos foliares e cotiledonares (Vieira e Dornelas, 1996 e referências). No presente trabalho, foram usados explantes cotiledonares como fonte de protoplastos. A mistura enzimática digeriu por completo a parede celular (Figura 12), obtendo-se um rendimento médio da ordem de 10 milhões de protoplastos $/ \mathrm{mL}$. A viabilidade média foi de $93 \% \pm 7,58$ (Figura 12). Resultados semelhantes foram relatados por Vieira \& Dornelas (1996), relativamente a culturas de protoplastos oriundos de explantes cotiledonares de $P$. edulis f. flavicarpa.

Os protoplastos foram plaqueados em gotas de agarose e meio líquido. Após $72 \mathrm{~h}$, as primeiras divisões puderam ser observadas em ambos os métodos de cultivo e, após sete dias, células derivadas de protoplastos cultivados em gotas de agarose já se apresentavam em terceira divisão e havia microcolônias (Figura 12). Não houve progresso nas culturas em meio líquido e as microcolônias sofreram oxidação após uma semana. A freqüência de divisão celular, em ambos os métodos de cultivo, são apresentadas na Figura 13. 

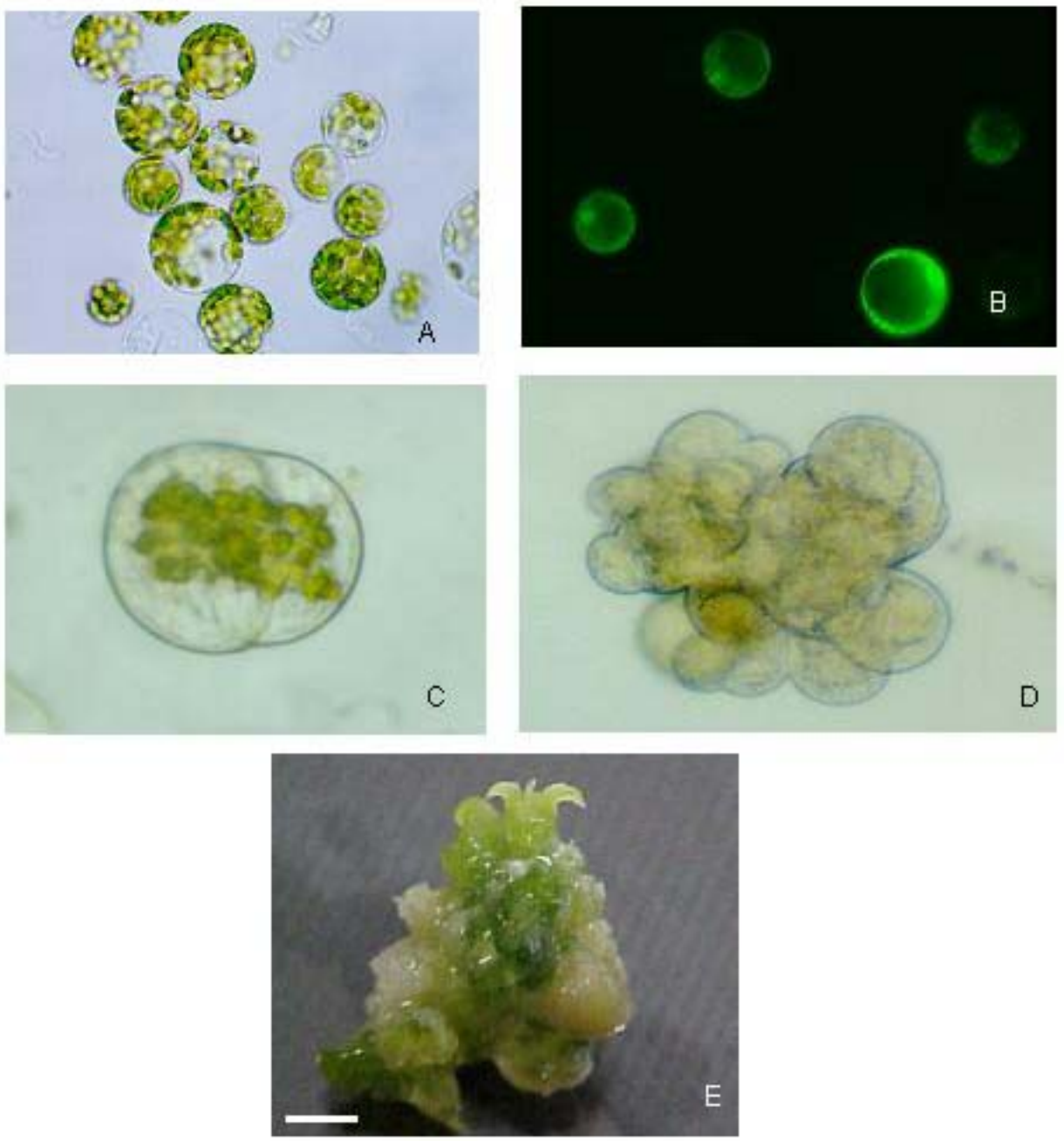

Figura 12 - Desenvolvimento de brotos a partir de protoplastos derivados de explantes cotiledonares de maracujá amarelo: A) protoplastos recém-isolados, sem a parede vegetal $(400 \mathrm{X})$; B) protoplastos tratados com FDA e visualizados ao microscópio de fluorescência para estudo da viabilidade $(400 \mathrm{X})$; C) primeira divisão celular, após 72 horas de cultivo (550 X; a seta indica a lamela média); D) microcolônias formadas aos 7 dias de cultivo (160 X); E) brotos formados após 90 dias em MS contendo $5 \%$ de água de coco e 1,0 $\mathrm{mg} / \mathrm{L}$ de BA $($ Barra $=870 \mu \mathrm{m})$ 


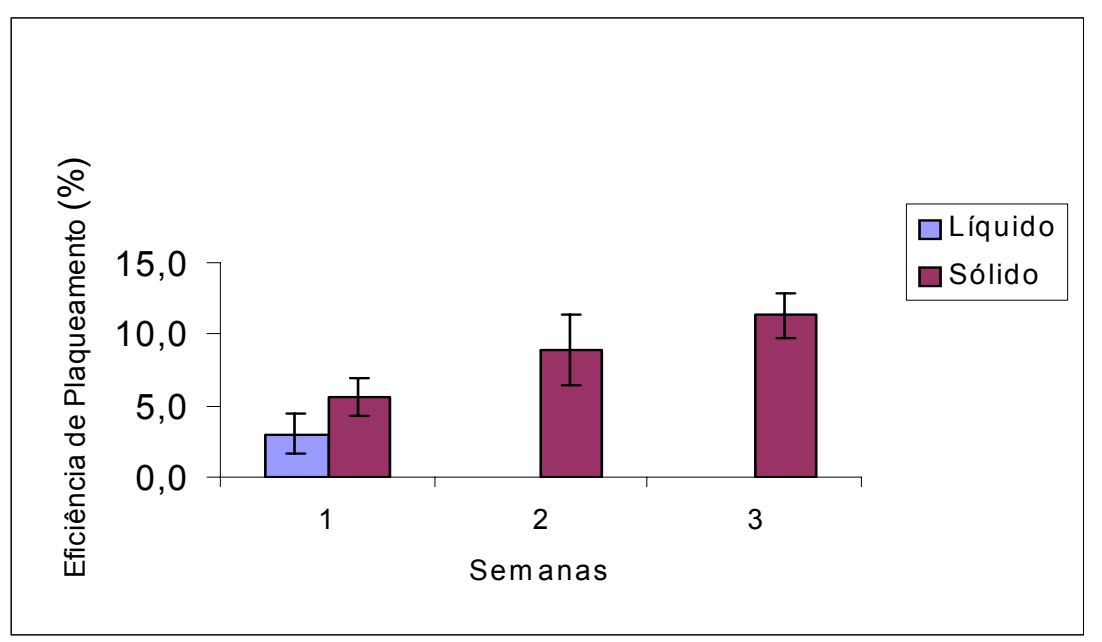

Figura 13 - Eficiência de Plaqueamento (EP) da cultura de protoplastos cultivados pelo sistema de gotas de agarose e em meio líquido a uma densidade de $1 \times 10^{5}$, aos 7,14 e 21 dias de idade

Como é usual, a redução da osmolaridade do meio de cultura foi feita por substituição gradual de parte do meio (1/3) por uma mistura de meio para protoplasto (K8P) e meio para células (K8). Estas diluições foram importantes para manter as divisões celulares. Foi observada maior porcentagem de microcolônias, aos 21 dias, nos cultivos em gotas de agarose. Estas microcolônias permaneceram por 45 dias em meio $\mathrm{K} 8$ (ou até atingirem 0,3 cm) e, então, foram transferidas para meio de desenvolvimento dos calos (item 3.3.3.1).

As análises mostraram que os tratamentos diferiram estatisticamente: no escuro, não houve desenvolvimento de calos em 0,1 mg/L de BA e 5,0 mg/L de ANA, enquanto estes aumentaram cerca de 10 vezes em $0,5 \mathrm{mg} / \mathrm{L}$ de BA; em condições de luz, o desenvolvimento dos calos foi mais expressivo aumentando em até 40 vezes (Tabela 4).

As análises estatísticas também mostraram que pelo menos dois tratamentos diferiram quanto à resposta morfogênica dos calos: observou-se que a combinação mais favorável foi $\mathrm{MS}+1,0 \mathrm{mg} / \mathrm{L}$ de $\mathrm{BA}+5 \%(\mathrm{v} / \mathrm{v})$ de água 
de coco, na qual $55 \%$ de calos formaram brotos (Figura 12). Nos demais tratamentos, a formação de brotos foi muito baixa (Tabela 5).

Estes resultados estão de acordo com os obtidos por D'Utra Vaz et al. (1993) que relataram que microcolônias cultivadas em meio MS suplementado com $5 \mathrm{mg} / \mathrm{L}$ de ANA e 0,25 mg/L de BA, sob condições de luz, apresentaram um desenvolvimento satisfatório e, aos 30 dias de cultivo, estavam em condições de serem transferidas para meio de regeneração (MS + 1,0 mg/L de BA). Aos 90 dias de cultivo, $40 \%$ dos calos apresentaram de dois a três brotos.

Vieira \& Dornelas (1996) cultivaram calos oriundos de protoplastos em MS suplementado com 2,0 mg/L de BA e 10\% de água de coco e, aos 56 dias, observaram que de 48 a $93 \%$ dos calos (de acordo com a espécie de Passiflora) apresentaram brotos. Uma média de 12 plântulas foi regenerada por calo de $P$. edulis f. flavicarpa.

Tabela 4. Peso $(\mathrm{mg})$ de calos derivados de protoplastos após 30 dias de cultivo em MS + 5,0 mg/L de ANA + 0,1 ou 0,5 mg/L de BA, sob condições de luz $\left(25 \mu \mathrm{M} . \mathrm{m}^{-2} \cdot \mathrm{s}^{-1}\right)$ ou no escuro*

\begin{tabular}{cccc}
\hline Peso inicial & \multicolumn{2}{c}{ Peso final } \\
& $\begin{array}{c}\text { Concentração } \\
\text { de BA (mg/L) }\end{array}$ & 0,1 & 0,5 \\
\hline \multirow{2}{*}{$4,2 \pm 1,1$} & Luz & $228,8 \mathrm{a}$ & $131,3 \mathrm{~b}$ \\
& Escuro & $62,4 \mathrm{c}$ & $5,4 \mathrm{~d}$ \\
\hline
\end{tabular}

*Médias seguidas por letras distintas diferem estatisticamente elo teste de Tukey $(\mathrm{P} \leq 0,05)$ 
Tabela 5. Resposta organogênica (em \%) de calos oriundos de protoplastos cultivados em MS + BA + água de coco, após 90 dias*

\begin{tabular}{cccc}
\hline $\begin{array}{c}\text { Concentração de BA } \\
(\mathrm{mg} / \mathrm{L})\end{array}$ & 0 & 5 & 10 \\
\hline 0,5 & $14,8 \mathrm{~b}$ & $25,9 \mathrm{ab}$ & $22,2 \mathrm{ab}$ \\
1,0 & $25,9 \mathrm{ab}$ & $55,5 \mathrm{a}$ & $25,9 \mathrm{ab}$ \\
2,0 & $29,6 \mathrm{ab}$ & $29,6 \mathrm{ab}$ & $37,0 \mathrm{ab}$ \\
\hline
\end{tabular}

*Os valores correspondem à média de 3 repetições e médias seguidas por letras distintas diferem estatisticamente elo teste de Tukey $(P \leq 0,05)$.

Com base nesses ensaios, as doses de 1,0 mg/L de BA e 5\% (v/v) de água de coco foram utilizadas para indução de brotos a partir de explantes hipocotiledonares, cotiledonares e foliares, nos experimentos de transformação genética.

A adição de água de coco é questionada por alguns pesquisadores por tratar-se de um composto natural cuja adição ao meio pode levar a resultados imprecisos e a uma resposta heterogênea por parte dos tecidos vegetais. Também, estudos com base em cortes histológicos têm mostrado que grande parte das estruturas formadas na superfície dos explantes foliares de maracujá, cultivados na presença de BA e água de coco, corresponde a primórdios de folhas e não gemas, não se prestando para a transformação genética (Beatriz Appezzato-da-Gloria, comunicação pessoal ${ }^{2}$ ). Isso tem levado a interpretações equivocadas por parte de alguns autores como Takahashi (2002) e Biasi et al. (2000).

\footnotetext{
${ }^{2}$ Docente do Depto. de Ciências Biológicas da ESALQ/USP
} 
Para o alongamento dos brotos e desenvolvimento de raízes, as culturas foram subcultivadas e transferidas para meio MS, MS/2 e MSM em frascos e magentas, por 90 dias. No entanto, os tratamentos não foram satisfatórios para induzir à regeneração de plântulas, não houve o alongamento dos brotos e todas as culturas sofreram oxidação.

Monteiro et al. (2000b) cultivaram brotos provenientes de explantes foliares de maracujá amarelo em MS e MSM. As diferenças mais importantes entre os meios MS e MSM são: um aumento na concentração de $\mathrm{P}, \mathrm{Ca}$ (nitrato de $\mathrm{Ca}$ ), Mg, S, Fe, Mn, Cu, Na e EDTA, um decréscimo na concentração de B, $\mathrm{Zn}$ e $\mathrm{Cl}$, e eliminação de I. Neste trabalho os autores observaram que as plântulas cultivadas em MS apresentaram clorose e redução no crescimento enquanto as plântulas cultivadas em MSM apresentaram folhas verdes e maior alongamento.

Sabe-se que para algumas espécies o etileno afeta a indução e o desenvolvimento de brotos (Reis, 2001), se acumulando em recipientes selados durante a cultura in vitro. Seu acúmulo não é constante, variando conforme o tipo de frasco e a vedação utilizada (Kumar et al., 1998). Em maracujá amarelo, o etileno mostrou-se nocivo à indução e desenvolvimento de brotos: Reis (2001) e Marota et al. (2001) verificaram o efeito inibitório do etileno na morfogênese in vitro em meio suplementado com ácido 1-aminocyclopropano-1-carboxilico (ACC) (precursor de etileno). O inverso foi observado ao adicionarem-se inibidores de etileno, como nitrato de prata $\left(\mathrm{AgNO}_{3}\right)$ e aminoethoxyvinylglycina (AVG).

Reis (2001) estudou a influência de diversos reguladores na multiplicação e alongamento de brotos a partir de ápices caulinares de maracujá amarelo. Este autor utilizou o meio $A$ que contém os sais de MS, o complexo vitamínico de B5 (Gamborg et al., 1968), $100 \mathrm{mg} / \mathrm{L}$ de inositol, 2\% $(p / v)$ de sacarose. A esse meio adicionou diversas combinações de fitorreguladores constituindo os meios: 
$\mathrm{B}$, com 2,15 mg/L de cinetina e $0,88 \mathrm{mg} / \mathrm{L}$ de ácido indol acético (AIA);meio MSM.

$\mathrm{C}$, com $1 \mathrm{mg} / \mathrm{L}$ de isopentenilladenina (2iP) e $1 \mathrm{mg} / \mathrm{L}$ de $\mathrm{AIA}$;

$\mathrm{D}, 1 \mathrm{mg} / \mathrm{L}$ de ácido giberélico $\left(\mathrm{GA}_{3}\right)$;

$\mathrm{E}$, com $2 \mathrm{mg} / \mathrm{L}$ de $\mathrm{GA}_{3}$;

F com 2,15 mg/L de cinetina, 4,15 mg/L de BA e 0,88 AIA.

Os resultados mostraram que todos os tratamentos contendo fitorreguladores reduziram o alongamento, enquanto o meio A (controle), promoveu o alongamento dos brotos.

Em contraste, Isutsa (2004) observou que a proliferação e o alongamento de brotos a partir de ápices caulinares de maracujá amerelo ocorreram em meio $\mathrm{MS}+5,0 \mathrm{mg} / \mathrm{L}$ de BA, e em maracujá roxo houve e necessidade de adicionar $4,0 \mathrm{mg} / \mathrm{L}$ de $\mathrm{GA}_{3}$ ao meio.

Já Dornelas \& Vieira (1993) usaram MS/2, sem adição de fitorreguladores, para o alongamento de brotos derivados da cultura de protoplastos de 3 espécies de Passiflora: $P$. edulis f. flavicarpa, $P$. amethystina e $P$. cincinnata. Os autores observaram que $P$. amethystina e $P$. cincinnata responderam melhor à regeneração (75 e 93\%, respectivamente) em comparação a $P$. edulis f. flavicarpa (48\%). Estes resultados confirmam que a regeneração de plantas de Passiflora é genótipo dependente.

Pelo exposto, permanece a dúvida quanto a melhor condição para induzir o alongamento de brotos.

Apesar da regeneração de plantas a partir de protoplastos de maracujá amarelo estar bem estabelecida em nosso Laboratório, neste trabalho o genótipo utilizado não respondeu satisfatoriamente. Sugere-se a revisão de alguns pontos importantes: a) alterar as concentrações de vitaminas do meio de cultura; $b$ ) testar a adição de fitorreguladores como $\mathrm{GA}_{3}$, por exemplo, ao meio de alongamento; $c$ ) adicionar inibidores de etileno ao meio de cultura. 


\subsubsection{Otimização da concentração de higromicina e fosfinotricina para seleção dos transformantes}

A eficiência da higromicina e da fosfinotricina na inibição do desenvolvimento de microcolônias derivadas da cultura de protoplastos está ilustrada na Figura 14. A inibição teve início na segunda semana após a aplicação dos agentes seletivos. Em poucos dias, os microcalos tornaram-se cloróticos, dependendo das doses de antibiótico e herbicida. As microcolônias cultivadas na ausência de agentes seletivos desenvolveram-se normalmente, sem o aparecimento de clorose (Figura 15).

O antibiótico higromicina mostrou-se eficiente como agente de seleção, causando redução drástica na divisão celular em doses acima de $7,0 \mathrm{mg} / \mathrm{L}$. Análises estatísticas indicaram que doses inferiores a $3,0 \mathrm{mg} / \mathrm{L}(P \leq 0,05)$ não conduzem a respostas diferentes. No entanto, houve diferença entre os tratamentos em relação ao controle (sem antibiótico), que mostrou 16\% de EP, após 21 dias de cultivo, quando doses acima de 4,0 mg/L foram aplicadas (Figura 14).

A concentração ideal de higromicina varia com a espécie e do tecido vegetal. Puonti-Kaerlas et al. (1992) usaram $15 \mathrm{mg} / \mathrm{L}$ de higromicina para selecionar protoplastos transformados de pêra. Okada et al. (2001) usaram 30 $\mathrm{mg} / \mathrm{L}$ para selecionar microcolônias transgênicas de batata-doce. Já em explantes foliares de maracujá, Takahashi (2002) relatou que apenas $5 \mathrm{mg} / \mathrm{L}$ higromicina foram suficientes para reduzir a morfogênese.

Propõe-se a utilização de $8 \mathrm{mg} / \mathrm{L}$ de higromicina para a seleção de células transformadas putativas de maracujá, após a segunda semana de cultivo.

Resultado bastante drástico foi observado com adição de fosfinotricina ao meio de cultura, havendo completa inibição do desenvolvimento das microcolônias na concentração de $0,3 \mathrm{mg} / \mathrm{L}$. Houve diferença entre os tratamentos em relação ao controle (sem herbicida), que mostrou $13 \%$ de EP, 
após 21 dias de cultivo, quando doses acima de $0,1 \mathrm{mg} / \mathrm{L}$ foram aplicadas (Figura 14).

Recomenda-se usar $0,3 \mathrm{mg} / \mathrm{L}$ de fosfinotricina para a seleção de células transformadas putativas de maracujá, após a segunda semana de cultivo.

Neste trabalho, utilizou-se o produto comercial Finale $®$ que contém o herbicida fosfinotricina como componente ativo da formulação. Este herbicida mostrou-se tão potente em inibir divisão celular quanto à fosfinotricina pura (Sigma) aplicada por Takahashi (2002). Asano et al. (1998) propõem a utilização de 2 a $5 \mathrm{mg} / \mathrm{L}$ do hercicida Bialaphos ${ }^{\circledR}$ para selecionar microcalos transgênicos putativos de Agrostis palustris.

Segundo Takahashi (2002), os agentes higromicina, canamicina, gentamicina e fosfinotricina mostram-se efetivos na inibição da morfogênese in vitro em maracujá amarelo; no entanto, a higromicina e a fosfinotricina mostraram maior potencial nos ensaios de seleção, já que baixas concentrações dessas substâncias foram suficientes para inibir a organogênese direta a partir de explantes foliares e hipocótilos, embora a comparação entre células isoladas (protoplastos) com tecidos íntegros (explantes foliares, cotiledonares ou outros) não seja adequada. 


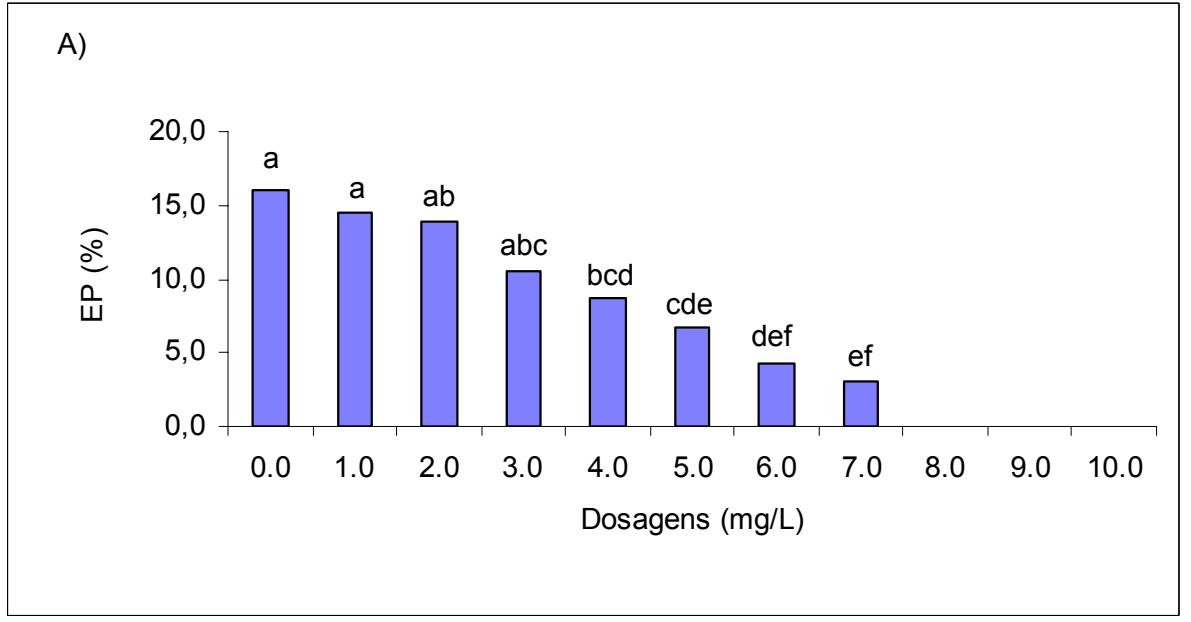

B)

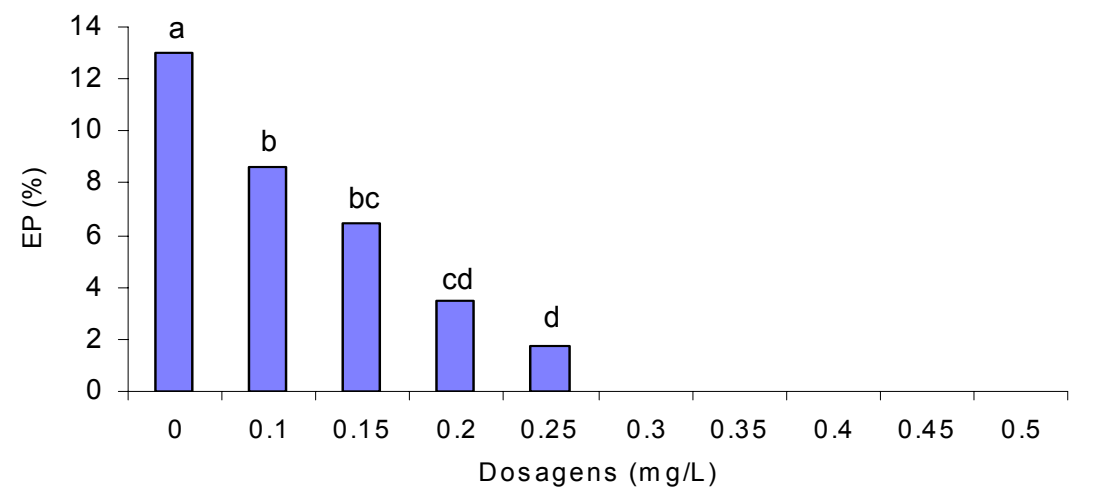

Figura 14 - Eficiência de plaqueamento (EP) de protoplastos avaliada após 14 dias da aplicação de diferentes doses de higromicina (A) e fosfinotricina (B). *Valores seguidos da mesma letra não diferem estatisticamente entre si pelo teste de Tukey $(P \leq 0,05)$ 

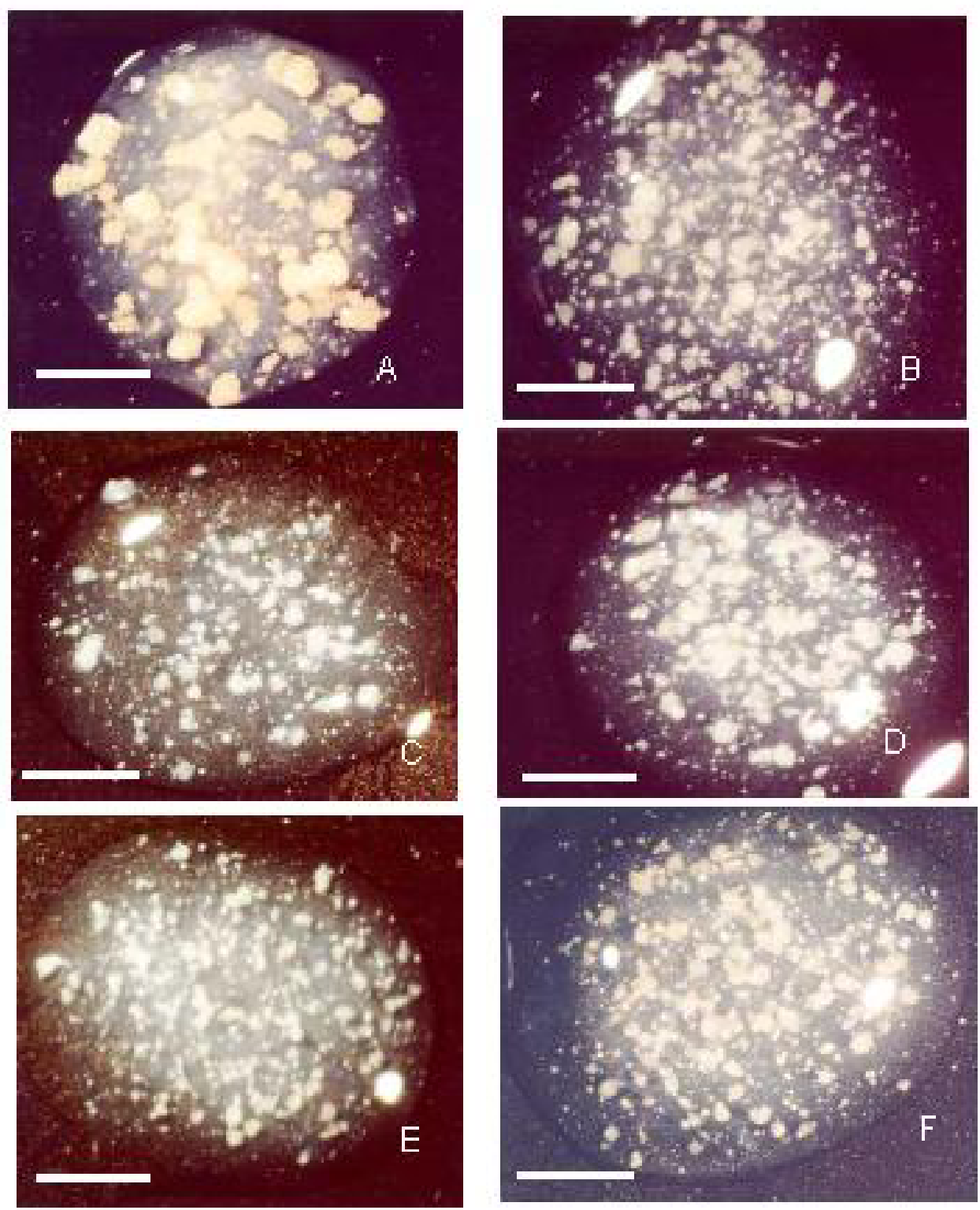

Figura 15 - Desenvolvimento de microcolônias a partir de protoplastos isolados de explantes cotiledonares após 14 da aplicação de diferentes doses de higromicina (em mg/L): A) 0,0; B) 1,0; C) 2,0; D) 3,0; E) 4,0; F) 5,0 (Barra $=870 \mu \mathrm{m})$ 


\subsubsection{Otimização das condições de eletroporação de protoplastos}

Quecini et al. (2002) transformaram protoplastos de Stylosanthes guianensis via eletroporação. Durante os ensaios, os autores avaliaram 3 tampões: I, II e III, formulados, respectivamente, a partir de From et al. (1987), Tada et al. (1990) e Walbot (1993). Melhores resultados foram os obtidos usando do tampão II, pois os demais foram prejudiciais à viabilidade dos protoplastos. Com o tratamento elétrico, os íons cloreto presentes nos tampões I e III promovem a formação do gás tóxico $\mathrm{Cl}_{2}$.

Neste trabalho, foi utilizado o tampão II, denominado ASP. Antes da eletroporação, os protoplastos de maracujá permaneceram em ASP por 30 min., mas todos plasmolizaram. Esta plasmólise foi atribuída à quantidade de manitol (0,4 M) presente no tampão. Alterando-se a molaridade do manitol para 0,7 , igual àquela da solução de lavagem (CPW-13), observou-se que a viabilidade aumentou para $83,4 \%$. Alteração da concentração de manitol no tampão (ASP) de eletroporação também foi realidada por Sági et al. (1995) em ensaios com protoplastos de banana.

A estabilidade da membrana é inversamente proporcional ao seu diâmetro: quanto maior a célula, menor será sua estabilidade. Portanto, há uma grande variação no campo elétrico a ser aplicado, dependendo da espécie e do explante que originou os protoplastos. Assumindo que o diâmetro dos protoplastos seja de $25 \mu \mathrm{m}$, o campo elétrico ideal para estudar expressão transiente pode variar de 250 a $1500 \mathrm{~V} / \mathrm{cm}$ (Rathus \& Birch, 1991).

Neste estudo, o diâmetro médio dos protoplastos foi de $27,75 \pm 9,3 \mu \mathrm{m}$ e visando à otimização das condições de eletroporação foi aplicada uma descarga elétrica proveniente de capacitor de $900 \mu \mathrm{F}$ associada a campos elétricos de 200, 250, 315, 375 e 400 V/cm. Nos gráficos da Figura 16, observase que tanto a viabilidade quanto a taxa de transformação diminuem com o acréscimo da voltagem. Análises estatísticas mostraram haver diferença na viabilidade dos protoplastos em relação à do controle a partir de $250 \mathrm{~V} / \mathrm{cm}$. 
Embora os valores não sejam diferentes do ponto de vista estatístico, campos elétricos de 200 a $250 \mathrm{~V} / \mathrm{cm}$ produziram taxas de transformação de 32,2 e $29,0 \%$, respectivamente.

Foram também aplicadas descargas de 800, 900 e $1000 \mu \mathrm{F}$ associadas a campos elétricos de 200 e $250 \mathrm{~V} / \mathrm{cm}$; a viabilidade dos protoplastos foi maior quando se usou o capacitor de $900 \mu \mathrm{F}$, independente da voltagem aplicada, 200 ou 250 V/cm (Figura 16).

Considera-se, portanto, que os parâmetros ideais para a eletroporação de protoplastos isolados de tecido cotiledonar são: $900 \mu \mathrm{F}$ de capacitância, sob voltagens de 200 a $250 \mathrm{~V} / \mathrm{cm}$, sendo que, nestas condições, obtêm-se 70,8 e $63,4 \%$ de células viáveis, respectivamente, e uma eficiência de transformação, ou seja, células expressando gfp, de 30\% (Figura 17). Estes resultados aproximam-se dos obtidos por Quecini et al. (2002) que observaram 50\% de expressão transiente em protoplastos de Sthylosantes eletroporados com $900 \mathrm{e}$ $1000 \mu \mathrm{F}$ de capaciância e campos elétricos de 200 e $250 \mathrm{~V} / \mathrm{cm}$.

A transformação via eletroporação de protoplastos é uma técnica eficiente e reduz o aparecimento de quimeras (Quecini, 1999; Quecini et al., 2002 Contudo, neste trabalho, para o isolamento, cultivo e formação de brotos a partir da cultura de protoplastos foram necessários cerca de nove meses, período demasiado longo se comparado ao de outros sistemas de regeneração. Além disso, isso limita o uso desta técnica, pois pode induzir a alterações genéticas e epigenéticas (Potrykus, 1991). Como alternativa, optando-se por usar o Agrobacterium tumefaciens como vetor de transferência de genes para o maracujá amarelo. 

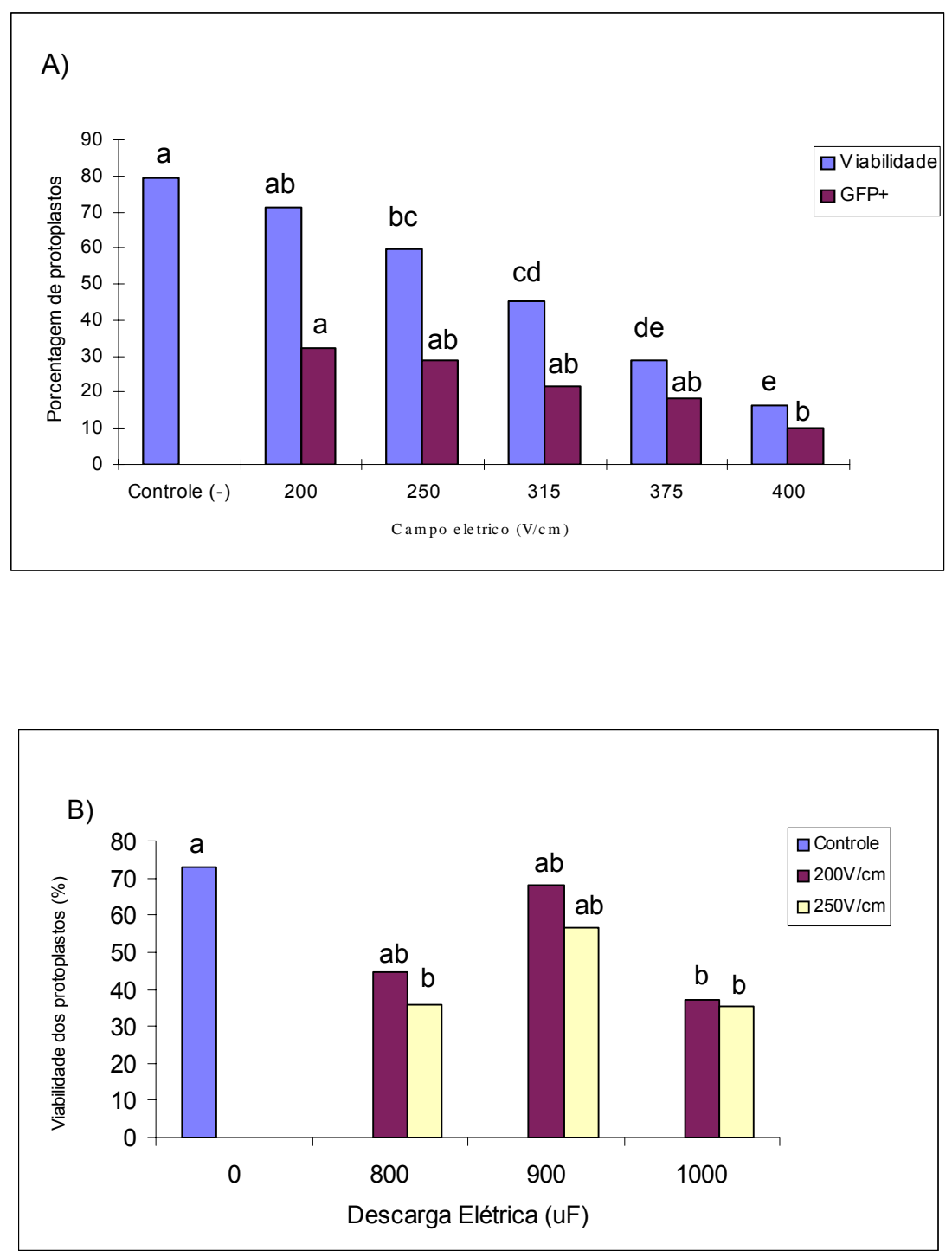

Figura 16 - Viabilidade e expressão da proteína GFP em protoplastos derivados de explantes cotiledonares de maracujá amarelo eletroporados com descarga elétrica proveniente de capacitor de $900 \mu \mathrm{F}$ associada a diferentes campos elétricos (A). Viabilidade sob descargas elétricas provenientes de capacitores de 800, 900 e $1000 \mu \mathrm{F}$ associadas a campos elétricos de 200 e $250 \mathrm{~V} / \mathrm{cm}$ (B). As letras sobre as barras correspondem ao resultado da comparação das médias pelo teste de Tukey $(P \leq 0,05)$. 

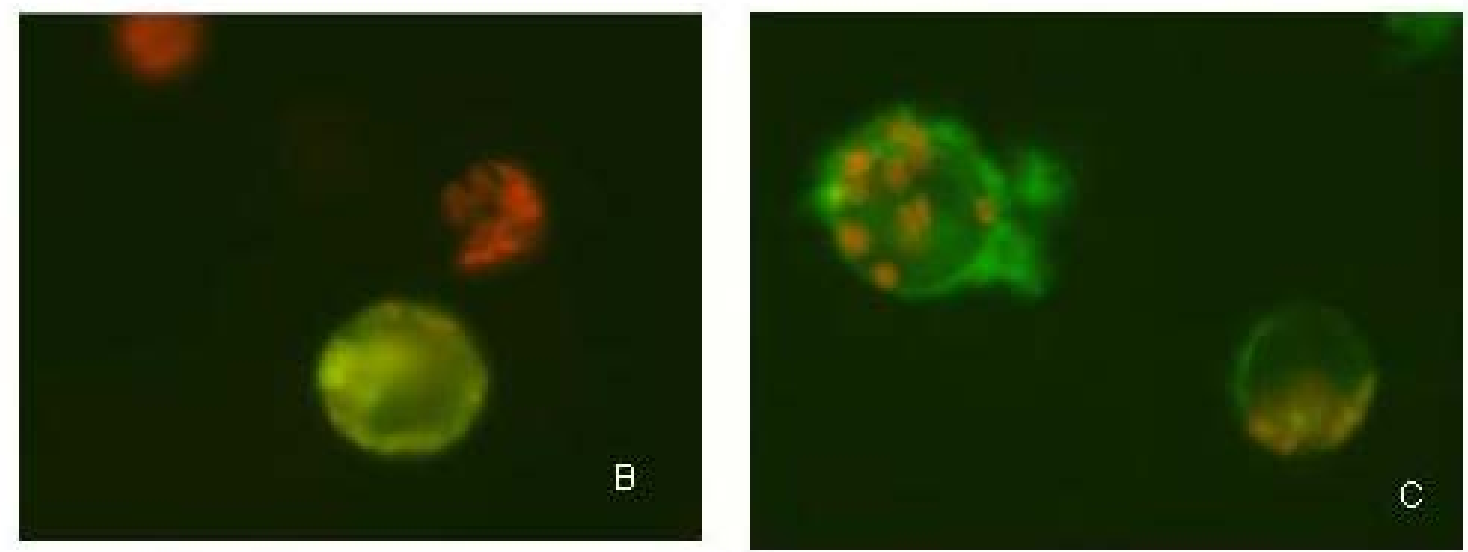

Figura 17 - Expressão da proteína GFP em protoplastos eletroprados de maracujá amarelo: A) sem DNA; B) $200 \mathrm{~V} / \mathrm{cm}$; C) $250 \mathrm{~V} / \mathrm{cm}$ $(400 \mathrm{X})$ 


\subsection{Transformação por Agrobacterium tumefaciens}

\subsubsection{Transformação das linhagens desarmadas de $A$. tumefaciens}

Foram obtidas 180 colônias de EHA 105 e 150 colônias de LBA 4404 após transformação com o plasmídeo pCattA 3300, e 98 colônias de EHA 105 e 78 de LBA 4404 após transformação com pCattA 3301. O screening por PCR de 3 a 5 colônias de cada linhagem serviu para confirmar a presença do plasmídeo com o inserto (Figura 18).

A

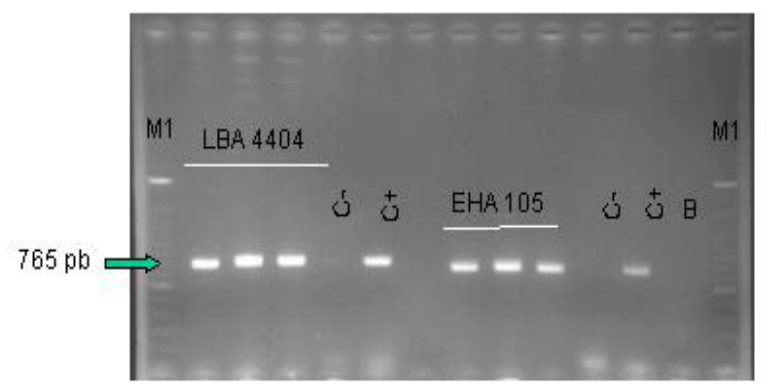

B

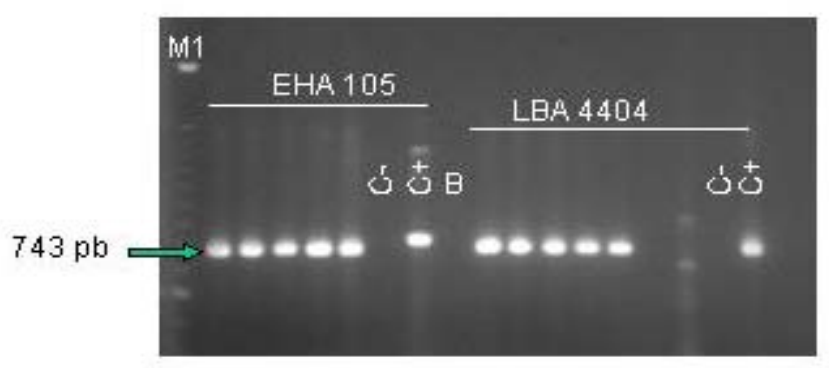

Figura 18 - Confirmação por PCR da transferência dos vetores pCattA 3300 (A) e pCattA 3301 (B) para as linhagens EHA 105 e LBA 4404 de A. tumefaciens (M1 - Ladder 100 pb; C+: pCattA 3300 e pCambia 3301. C-: LBA 4404 e EHA 105 não transformadas; B: PCR sem DNA molde 


\subsubsection{Cultura de explantes}

Em todos os tipos de explantes, observou-se o aparecimento de brotos em MS + 1,0 mg/L de BA + 5\% de água de coco (Figuras 19).

A organogênese teve início após cinco a seis dias, nas extremidades do explante, com formação de estruturas diferenciadas (pequenas gemas). Aos 10 dias, ocorreu a proliferação acentuada dessas estruturas e, eventualmente, observaram-se pequenos brotos com folhas expandidas. A resposta nos tecidos foliares iniciou-se com a formação de protuberâncias na superfície do explante, a partir das quais as gemas tiveram origem. Estas protuberâncias e a eventual formação de gemas foram caracterizadas por Juliana A. Fernando (comunicação pessoal $^{3}$ ). A formação de gemas ocorreu na região da nervura central, principalmente, e estendeu-se por toda a borda do disco. Estruturas semelhantes foram observadas por Takahashi (2002) em explantes foliares de maracujá amarelo var. Sul Brasil.

A organogênse direta a partir de discos foliares de maracujá amarelo também foi relatada por Otahola (2000), utilizando baixas concentrações de BA (0; 0,3; 0,6; 0,9 e 1,2 mg/L). A melhor resposta foi observada após 35 dias em meio com $0,6 \mathrm{mg} / \mathrm{L}$ de $\mathrm{BA}$, onde $44 \%$ dos explantes formaram brotos. $\mathrm{O}$ autor ressaltou que a presença da nervura central no explante é essencial; também relatou a indução de calos proporcionada por BA, semelhantemente ao observado em P. suberosa (Monteiro et al., 2000).

Nos explantes cotiledonares, a resposta iniciou-se aleatoriamente em regiões da borda. Nos hipocótilos, a resposta se deu nas extremidades do explante. A análise estatística indicou que pelo menos um dos tratamentos difere quanto à resposta morfogenética e que os explantes hipocotiledonares foram mais responsivos, pois em $90 \%$ deles houve formação de brotos. Nos explantes cotiledonares e foliares houve $50,0 \%$ e $35,6 \%$ de regeneração, respectivamente (Tabela 6). Os explantes hipocotiledonares apresentaram uma

\footnotetext{
${ }^{3}$ Doutoranda do Programa de Pós-graduação de Biologia Vegetal, Instituto de Biologia, Unicamp
} 
média de 2 brotos regenerados por explante enquanto os explantes foliares e cotiledonares apresentaram 1,4 e 0,8 brotos/explante, respectivamente. Com base nisso, decidiu-se por usar explantes derivados de tecido hipocotiledonar nos ensaios de transformação, além de discos foliares. Este último foi incluído pela facilidade de obtenção.

Esses resultados concordam com os obtidos por Juliana A. Fernando (comunicação pessoal $^{4}$ ) que analisou, anatomicamente, a regeneração de brotos a partir de explantes foliares e hipocotiledonares de maracujá amarelo var. FB-100 cultivados em meio $\mathrm{MS}+1,0 \mathrm{mg} / \mathrm{L}$ de $\mathrm{BA}+5 \%$ de água de coco. Os explantes hipocotiledonares foram mais responsivos no que concerne à formação de gemas e a formação dos meristemóides ocorreu nas camadas superficiais do expante.

Este conjunto de informações sugere que a técnica de transformação genética de maracujá via A.tumefaciens é a mais adequada. As células vegetais colonizadas pelo Agrobacterium, após sua inoculação ou co-cultivo, têm localização superficial (Alves, 1999), levando à obtenção de maior número de brotos transgênicos putativos.

\footnotetext{
${ }^{4}$ Doutoranda do Programa de Pós-graduação de Biologia Vegetal, Instituto de Biologia, Unicamp
} 

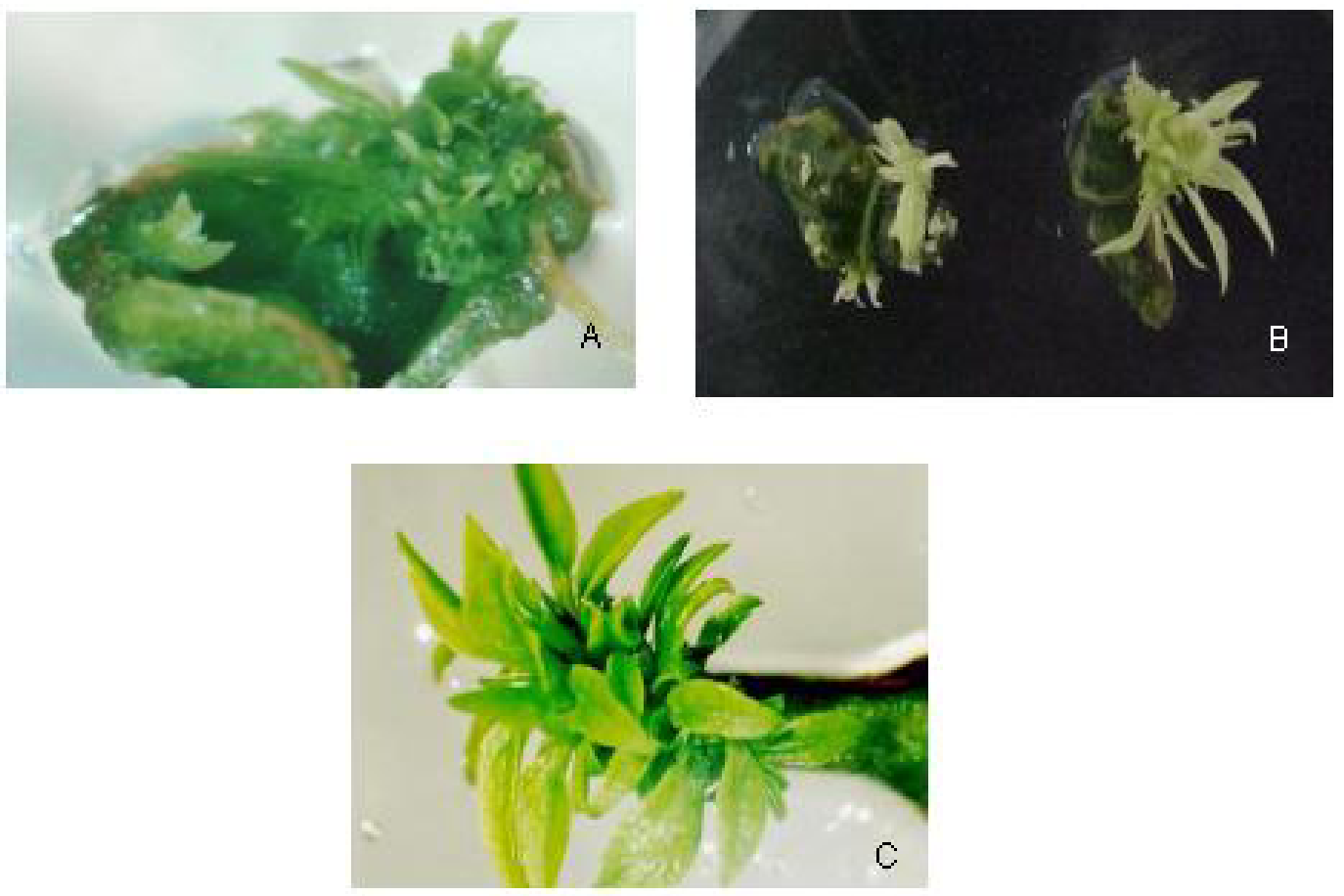

Figura 19 - Formação de gemas e brotos em $\mathrm{MS}+1,0 \mathrm{mg} / \mathrm{L}$ de $\mathrm{BA}+5 \%$ de água de coco, aos 30 dias. Explante cotiledonar $(A)$, foliar $(B)$ e hipocotiledonar (C)

Tabela 6. Resposta morfogênica em explantes de maracujá marelo

\begin{tabular}{ccc}
\hline Tipo de explante & $\begin{array}{c}\text { Explantes com regeneração } \\
(\%)^{*}\end{array}$ & $\begin{array}{c}\mathrm{N}^{\circ} \text {. de brotos regenerados } \\
\text { por explante* }\end{array}$ \\
\hline Cotiledonar & $35,6 \mathrm{~b}$ & $0,8 \mathrm{~b}$ \\
Foliar & $52,4 \mathrm{~b}$ & $1,4 \mathrm{ab}$ \\
Hipocotiledonar & $93,2 \mathrm{a}$ & $2,0 \mathrm{a}$ \\
\hline
\end{tabular}

${ }^{\star}$ Média de 3 repetições. Médias seguidas da mesma letra não diferem estatisticamente entre si pelo teste de Tukey $(P \leq 0,05)$ 


\subsubsection{Infecção de explantes de maracujá amarelo por Agrobacterium tumefaciens}

Um fator importante na transformação genética via Agrobacterium é o tempo em que a linhagem bacteriana permanece em contato com o explante. Em plantas cítricas verifica-se que este tempo pode variar de 15 a 30 min.: Almeida (2002), por exemplo, adotou 20 min., usando a linhagem EHA 105 de A. tumefaciens. Já Manders et al. (1994), utilizaram $30 \mathrm{~min}$ e a linhagem GV3111SE para transformar explantes foliares de maracujá. No presente trabalho, decidiu-se por adotar 20 min.

O período de co-cultivo é um outro fator que interfere na eficiência de transformação genética via Agrobacterium. Ensaios de transformação de plantas de maracujá e de citros têm utilizado 2 a 3 dias de co-cultivo (Manders et al., 1994; Yang et al., 2000; Almeida, et al., 2003). Neste trabalho, o período de co-cultivo de 3 dias foram suficientes para a infecção.

É consenso que a aplicação de compostos fenólicos, como acetoseringona, favorece a infecção do Agrobacterium durante a inoculação da bactéria e o co-cultivo (Alves, 1999 e referências). Neste estudo, foi observado que a aplicação de $100 \mu \mathrm{M}$ de acetoseringona ao meio de inoculação e cocultivo foi essencial para induzir a transferência do DNA ao genoma hospedeiro (dados não apresentados).

Porém, segundo Almeida (2002) nem sempre a aplicação de acetoseringona favorece a transformação. Este autor relatou que a adição de 100 e $200 \mu \mathrm{M}$ acetoseringona não favoreceu a obtenção de plantas transgênicas de citros, associando este fato à presença de muitos compostos fenólicos liberados pelo ferimento no explante de citros que favorecem a infecção pelo Agrobacterium. O fornecimento exógeno de acetoseringona, quando combinado a compostos fenólicos endógenos, pode contribuir negativanente. 
Para a eliminação da agrobacteria, após o co-cultivo, os explantes foram transferidos para meio MS contendo $250 \mathrm{mg} / \mathrm{L}$ de cefotaxima. Esta concentração de antibiótico foi suficiente para inibir o crescimento das agrobactérias sem afetar a regeneração dos brotos. A cefotaxima é um dos antibióticos mais utilizados para o controle e eliminação do Agrobacterium e, dependendo de sua concentração, tem sido considerada, como estimulante de regeneração de brotos. D'Utra Vaz et al. (1993) observaram que $250 \mathrm{mg} / \mathrm{L}$ de cefotaxima foram essenciais para induzir a divisão célular em protoplastos de maracujá. No entanto, a concentração de 400 mg/L reduziu drasticamente a EP. Sarma et al. (1995) também observaram que a dose de $500 \mathrm{mg} / \mathrm{L}$ de cefotaxima foi prejudicial à maturação de embriões somáticos em Picea sitchensis. Manders et al. (1994) transformaram explantes foliares de maracujá com $A$. tumefaciens e para a eliminação da bactéria subcultivaram estes explantes a cada 14 dias em doses decrescentes de cefotaxima (500, 250, 100 e 0 mg/L de meio de regeneração).

\subsubsection{Análises ultra-estruturais da formação de microfibrila de celulose}

Uma vez em contato com as células vegetais, as bactérias sintetizam microfibrilas de celulose para favorecer a formação de agregados de células bacterianas em volta do tecido vegetal ferido. A adesão de Agrobacterium à célula vegetal hospedeira é um dos primeiros passos do processo que leva à formação do tumor (Matthysse e McMahan, 1998). Este processo ocorre em duas etapas: na primeira, as agrobactérias são atraídas em direção à célula vegetal por quimiotactismo positivo em relação a moléculas-sinal (essencialmente compostos fenólicos, aminoácidos e monossacarídeos) que são exsudadas pelas células da planta que sofreu algum tipo de dano ou ferimento (Tzfira \& Citovsky, 2000); no segundo passo, as bactérias sintetizam filamentos de celulose que levam a uma ligação irreversível, propiciando uma melhor fixação da bactéria na célula hospedeira (Matthysse et al., 2000). 
Os genes envolvidos nessa ligação agrobactéria-célula vegetal estão localizados no cromossomo da bactéria e incluem chvA, chvB, pscA (ou exoC), att, chvD, chvE, miaA, ros, chvG e chvl (Andrade et al., 2003), codificando produtos envolvidos na adesão durante o processo de infecção. Mutações em qualquer um desses locos, resultam em linhagens incapazes de infectar plantas (Gelvin, 2000).

A fim de investigar a formação de microfibrilas de celulose em explantes de maracujá infectados com $A$. tumefaciens, os explantes foram analisados sob microscopia eletrônica de varredura, três dias após a infecção (co-cultivo). Foi observada uma grande formação de fibrilas pela linhagem EHA 105, enquanto a linhagem LBA 4404 formou pouca ou nenhuma fibrila (Figura 20). Isto indica que a EHA 105 é mais virulenta em $P$. edulis, pelo menos em ensaios in vitro.

\subsubsection{Ensaio histoquímico e localização anatômica da expressão transiente do gene uidA}

Apesar de a análise estatística não ter detectado diferença na capacidade de infecção das linhagens de A. tumefaciens, a EHA 105 mostrouse mais eficiente em transformar explantes de maracujá do que a LBA 4404, confirmando os dados de microscopia eletrônica referentes à formação de microfibrilas de celulose. A freqüência de explantes foliares e hipocotiledonares transformados pela linhagem EHA 105 foi de 86 e $83 \%$, respectivamente. A LBA 4404 foi capaz de infectar 61 e 53\% desses explantes (Tabela 7).

O maracujá amarelo parece, de fato, mais susceptível à EHA 105. Esta linhagem é derivada da A281, supervirulenta (Hood et al., 1993) o que explica a agressividade aqui constatada e também demonstrada para citros (Bond \& Roose, 1998).

As regiões onde houve a expressão estável de uidA, verificada pela formação de cristais de GUS, coincidem com as regiões onde ocorreu a 
formação de brotos nos explantes foliares e hipocotiledonares (Figura 21). Isso favoreceu a obtenção de brotos transgênicos, como será apresentado adiante.

Após 30 dias de cultivo, os explantes foram examinados histologicamente. $\mathrm{A}$ análise indicou que essas regiões correspondem a áreas meristemáticas. A Figura 21 mostra os cortes histológicos das células meristemáticas, formadas no explante hipocotiledonar, onde se observa a expressão estável do gene uidA pela presença de cristais de GUS.

Os estudos anatômicos são importantes não apenas para a confirmação da via de regeneração in vitro, mas também para a determinação dos tipos celulares a partir dos quais surgem as gemas adventícias. Estas informações são de grande interesse, especialmente em sistemas de transferência de genes (Matsumoto et al., 1996). Em algumas espécies, a baixa eficiência de transformação pode ser atribuída ao fato de a regeneração de plantas ocorrer a partir de células meristemáticas as quais não são acessíveis à bactéria (Mukhopadhyay et al., 1992).

Segundo Fernando et al. (2004) a região meristemática está localizada nas camadas superficiais dos explantes hipocotiledonares de maracujá amarelo. Isto pode ser considerado vantajoso para a transformação genética via Agrobacterium, pela facilidade das bactérias infectarem essas células superficiais. 
Tabela 7. Expressão da $\beta$-glucoronidase (GUS+) em explantes de maracujá amarelo infectados por Agrobacterium tumefaciens.

\begin{tabular}{clcc}
\hline Tipo de explante & Linhagem & $\begin{array}{c}\mathrm{N}^{\circ} \text { de explantes } \\
\text { inoculados }\end{array}$ & $\begin{array}{c}\% \text { de explantes } \\
\text { GUS+ \%* }\end{array}$ \\
\hline Foliar & LBA 4404 & 37 & $61,07 \mathrm{a}$ \\
Hipocotiledonar & EHA 105 & 42 & $86,08 \mathrm{a}$ \\
& LBA 4404 & 15 & $53,33 \mathrm{a}$ \\
& EHA 105 & 18 & $83,33 \mathrm{a}$
\end{tabular}

*Média de três repetições; as letras, ao lado dos valores indicam que as médias, por explante, não diferem estatisticamente $(P \leq 0,05)$
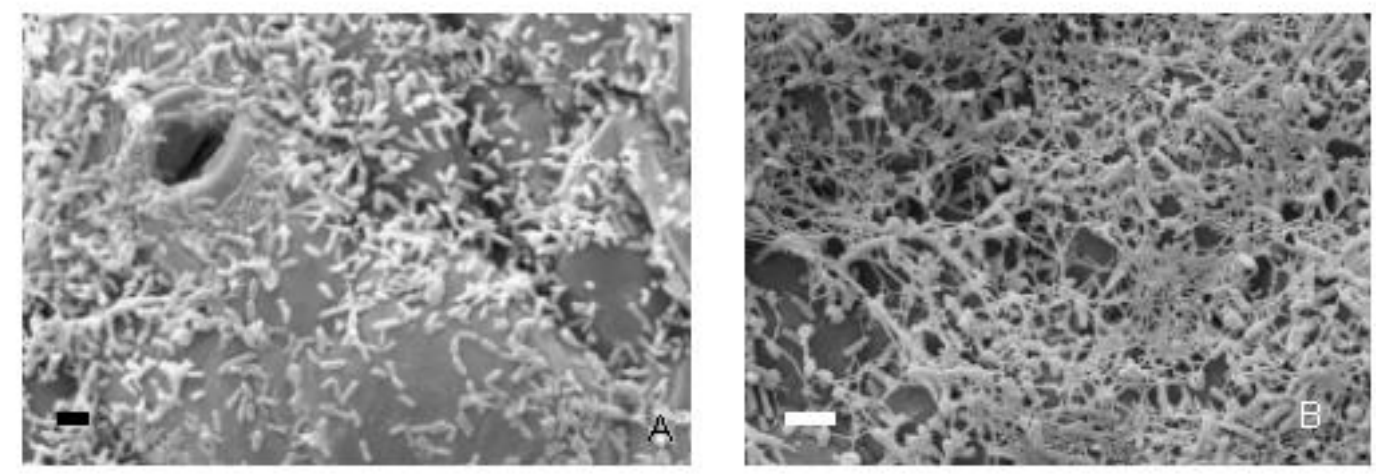

Figura 20 - Microscopia eletrônica de varredura mostrando a formação de fibrilas de celulose por $A$. tumefaciens em explantes foliares de maracujá amarelo, três dias após a infecção, na presença de acetoseringona: A) LBA 4404 (Barra = $2 \mu \mathrm{m})$; B) EHA 105 (Barra = $1 \mu \mathrm{m})$ 

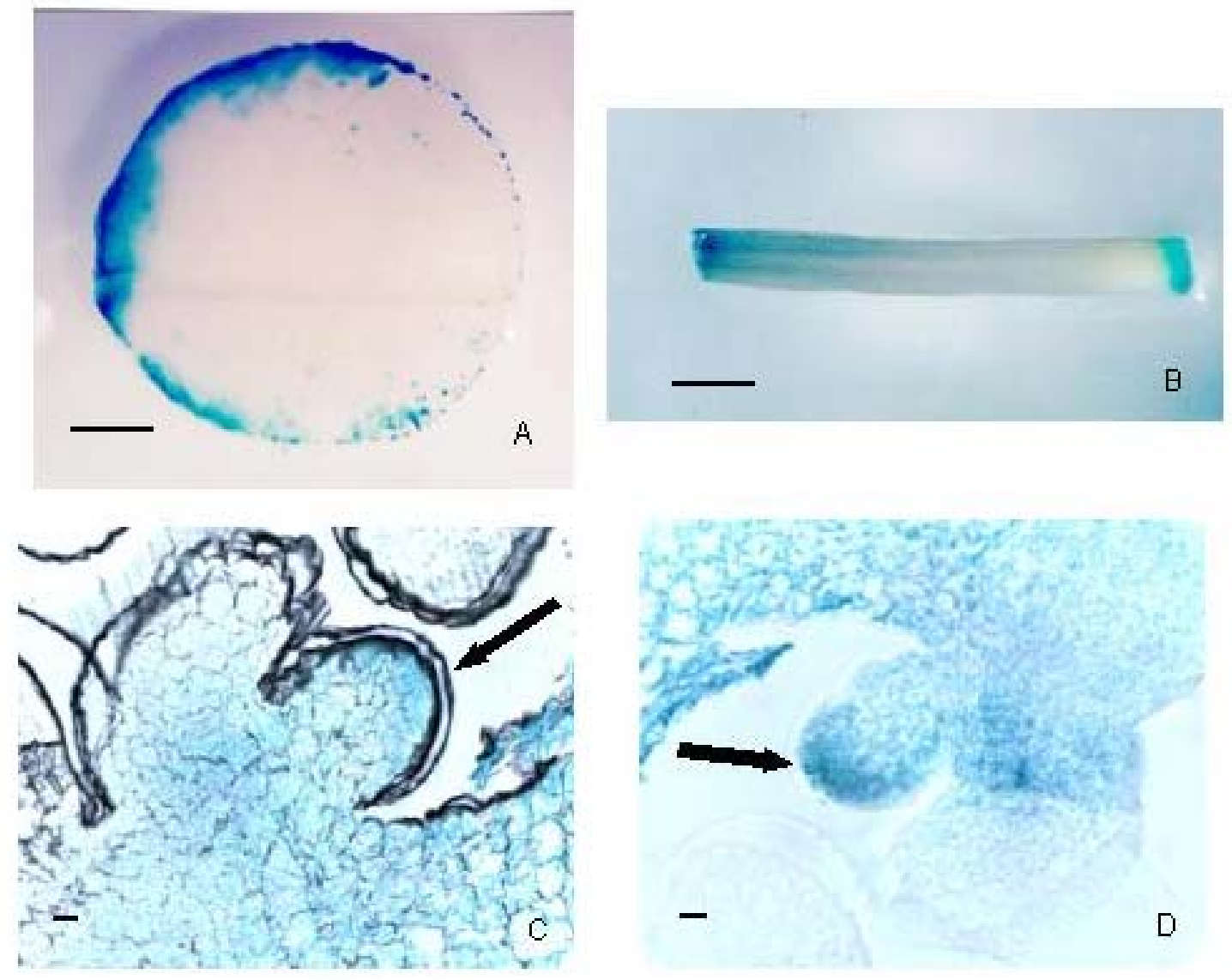

Figura 21 - Expressão de uidA em explantes de maracujá amarelo infectados com a linhagem EHA 105 de A. tumefaciens. Expressão transiente em explante foliar (A) e hipocotiledonar $(B)$ (Barra $=870 \mu \mathrm{m})$. Cortes histológicos de hipocótilos mostrando cristais de GUS em células meristemáticas, após 30 dias da inoculação (C e D) (Barra $=25 \mu \mathrm{m})$. As setas indicam a região meristemática 


\subsubsection{Regeneração de plantas a partir de explantes de maracujá amarelo infectados com A. tumefaciens}

Os explantes foliares foram cultivados em meio contendo fosfinotricina $(0,1 \mathrm{mg} / \mathrm{L}) 10$ dias depois do co-cultivo. Após 25 dias, 18 explantes mostraram regiões verdes (protuberâncias), sendo resistentes ao herbicida, dos quais 8 apresentaram brotos. Foram obtidos 10 brotos regenerados a partir de um total de 67 explantes foliares originalmente infectados.

Os explantes hipocotiledonares desenvolveram-se em meio livre de agente seletivo. Após 45 dias de cultivo na presença de $250 \mathrm{mg} / \mathrm{L}$ de cefotaxima, usada para eliminar a agrobactéria, foram obtidos 165 brotos a partir de um total de 246 explantes originalmente infectados (Figura 22).

A fosfinotricina é considerada um agente seletivo de contato, ou seja, tem a capacidade de selecionar apenas os tecidos que estão em contato com o meio. As regiões meristemáticas formadas nos explantes hipocotiledonares, pela sua anatomia, não entram em contato com o meio não permitindo que o agente exerça sua função, ocorrendo assim o crescimento de células não transformadas (Franscisco J. L. Aragão, comunicação pessoal ${ }^{5)}$. Isso foi observado em ensaios de transformação de feijão a partir de ápices embriogênicos: um grande número de brotos não transgênicos formou-se em meio contendo glufosinato de amonio ou fosfinotricina (Aragão et al., 2002). Apesar desta restrição, vários trabalhos têm sido realizados com o intuito de estabelecer as dosagens de fosfinotricina capazes de inibir a morfogênese in vitro em diversos explantes. Souza-Júnior et al. (2001) relataram que doses de $25 \mathrm{mg} / \mathrm{L}$ de fosfinotricina foram suficientes para impedir o desenvolvimento de embriões somáticos a partir de embriões imaturos de mamão. Takahashi (2002) observou que o desenvolvimento de brotos a partir de explantes foliares de maracujá amarelo var. Sul Brasil foi inibido quando 2,0 mg/L de fosfinotricina foram aplicados ao meio de cultura.

\footnotetext{
${ }^{5}$ Pesquisador, Embrapa Recursos Genéticos e Biotecnologia
} 
O glufosinato de amônia, que é um análogo químico sintético do herbicida Bialaphos $₫$, e atua como um inibidor competitivo da enzima glutamina sintetase (GS). Esta enzima está envolvida na assimilação de amônia e tem função na regulação do metabolismo de nitrogênio (De Block et al., 1987). A inibição da enzima causa acúmulo de $\mathrm{NH}^{+}$na célula. Este acúmulo causa a morte das células (Silva Filho \& Falco, 2001).
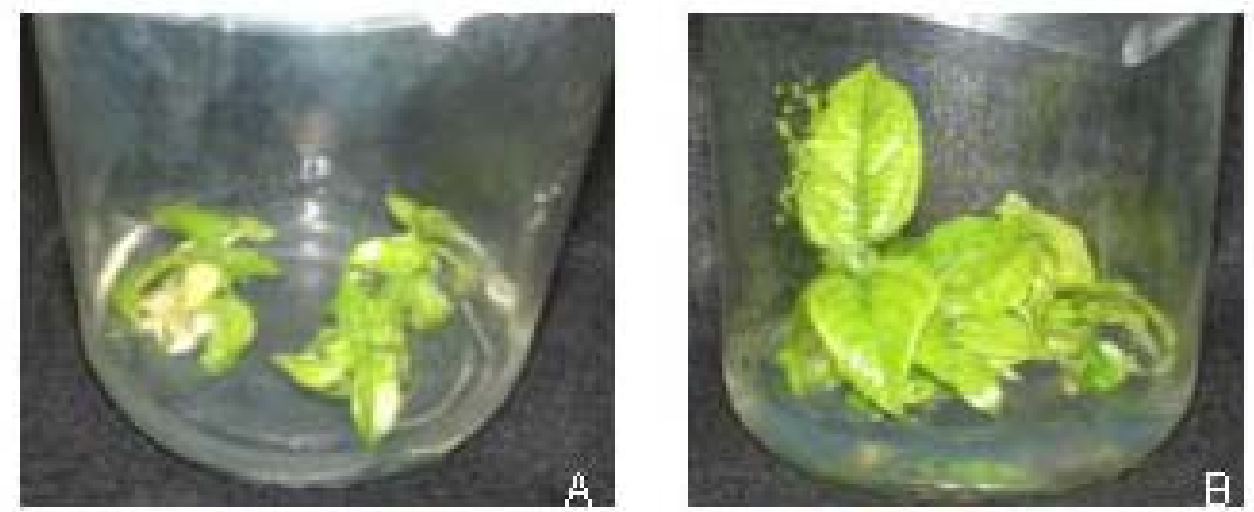

Figura 22 - Brotos de maracujá amarelo regenerados 60 dias após a inoculação com A. tumefaciens contendo pCattA 3300. A) Explantes foliares; B) Explantes hipocotiledonares 


\subsubsection{Análise molecular dos transformantes}

\subsubsection{Via reação em cadeia da polimerase (PCR)}

Neste trabalho, dos 165 brotos regenerados a partir de explantes hipocotiledonares, 27 apresentaram-se PCR+ para o gene att A, ou seja, $16,4 \%$.

Dos 10 brotos regenerados a partir de explantes foliares sob seleção, 4 apresentaram-se PCR+ para o gene att A, ou seja, 40\%, havendo, portanto, uma taxa de escape de $60 \%$. Estes dados indicam que há necessidade de se avaliar uma dosagem maior de fosfinotricina a ser aplicada ao meio de cultura para que a seleção in vitro de explantes foliares de maracujá seja eficiente.

O gel de eletroforese mostrando a banda de 765 pb referente à seqüência do gene att $\mathrm{A}$ amplificada a partir do DNA dos brotos transgênicos é apresentado na Figura 23. Não houve amplificação a partir do DNA genômico proveniente da planta matriz não transformada.

Foi obtida uma eficiência de transformação de 6 e 11\% quando se usou explante foliar e hipocotiledonar, respectivamente (Tabela 8). Esta diferença pode estar relacionada à melhor capacidade de regeneração de brotos a partir de explantes hipocotiledonares. Estas taxas de transformação concordam com as relatadas na literatura para outras espécies frutíferas (Yu, et al., 2002; Almeida et al., 2003; Boscariol, 2004). 


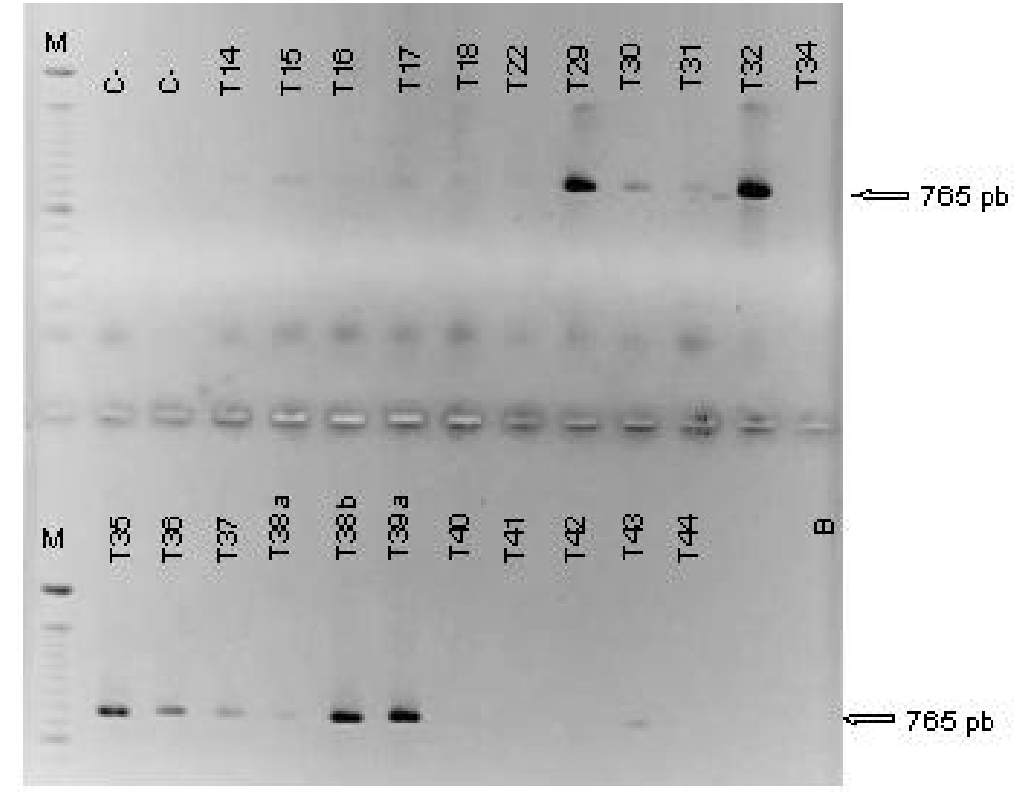

Figura 23 - Análise por PCR dos brotos transgênicos putativos usando primers que amplificam o fragmento de 765 pb do gene att A. Plântulas regenerados a partir de explantes hipocotiledonares transformados com a linhagem LBA 4404 (T14, T17, T18, T37, T38ab, T42, T43 e T44) e com a EHA 105 (T22, T30, T31, T32, T34, T35, T36, T39a, T40 e T41). Brotos regenerados a partir de explantes foliares transformados com a linhagem LBA 4404 (T15, T16 e T29). C-: planta não transformada. M: Ladder 100 PB. B: reação de PCR na ausência de DNA molde

\subsubsection{Análise dos transcritos de att A por RT-PCR}

Apesar da integração do gene att $\mathrm{A}$ ter sido comprovada por PCR, isto não indica que o gene esteja sendo expresso. O chamado efeito de posição, relacionado ao loco no qual o gene foi inserido, faz com que variações na expressão de um gene sejam observadas, inclusive até o seu total silenciamento (Mlynarova et al., 1996).

Assim, metodologias que demonstrem a expressão do gene inserido são necessárias para a caracterização molecular das plantas transformadas. Para a 
confirmação da transcrição do gene att A foi usada a técnica da RT-PCR (Reverse Transcriptase - Polymerase Chain Reaction). Foram analisadas 3 plantas PCR+ e as respectivas matrizes, como controle negativo. Os géis revelaram que o transgene att $A$ está sendo expresso nas três plantas analisadas (Figura 24).

Segundo Kohli et al. (2003) a maioria dos eventos de integração se dá em regiões onde o gene não é transcrito, ou seja, em regiões teloméricas e subteloméricas do cromossomo. Andrade et al. (2003) sugerem que a integração do DNA se dá ao acaso no genoma hospedeiro. Já Tinland (1996) discorda, relatando que há evidências que a fita $T$ integra-se, preferencialmente, em regiões ativas do cromossomo.

Essas evidências estão relacionadas com o envolvimento de proteínas sintetizadas pela bactéria e das extremidades do T-DNA, com maior ênfase à borda 5', que é conservada, que promovem a transferência e a integração do DNA exógeno no genoma hospedeiro. Esta questão da integração preferencial é, sem dúvida, uma vantagem do método aqui usado (via Agrobacterium) em relação aos procedimentos diretos de transformação (via biobalística ou eletroporação).

\subsection{Bioensaios}

\subsubsection{Resistência à Xanthomonas axonopodis pv. passflorae}

Para confirmar os achados por RT-PCR e verificar se as plantas transgênicas são resistentes ou tolerantes à $X$. axonopodis pv. passiflorae, foi realizado um bioensaio, baseando-se na metodologia utilizada por Boscariol (2004), a qual consiste em utilizar folhas destacadas para inocular o patógeno. Neste ensaio, foram avaliadas as 31 plantas PCR+ para att A, incluindo as RTPCR+. Como controles, foram usadas as plantas matrizes, ou seja, as que deram origem às plantas transformadas. A avaliação, realizada após 7 dias da 
inoculação, revelou que 10 plantas $(32,2 \%)$ não apresentaram os sintomas provocados pelo patógeno, incluindo as 3 plantas RT-PCR+. Estes resultados foram confirmados aos 12 dias. Os sintomas apresentados pelas folhas em decorrência da inoculação do patógeno foram caracterizados por um halo amarelado na região lesionada (Figura 24).

Estes bioensaios sugerem que as plantas de maracujá com o transgene att $\mathrm{A}$ são resistentes ao patógeno, pois não apresentaram os sintomas da doença, dada a ação bactericida do peptídeo.

Essa ação foi descrita, também, para citros (Boscariol, 2004) contra Xanthomonas axonopodis pv. citri e outras culturas como maçã (Ko et al., 2000) e pêra (Reynoird et al., 1999) que também mostraram redução dos sintomas causados por Erwinia amylovora quando inoculadas com o patógeno. Estas duas espécies foram transformadas com o gene att E, oriundo de Hyalophora cecropia.

\subsubsection{Resistência ao herbicida Finale ${ }^{\circledR}$}

Com o intuito de avaliar a expressão do gene bar nas 31 plantas PCR+ para o gene att $\mathrm{A}$, discos foliares foram excisados e cultivados em meio com 0,3 $\mathrm{mg} / \mathrm{L}$ de fosfinotricina. Esta concentração é aquela capaz de selecionar explantes resistentes, com base na curva de morte estabelecida previamente em nosso laboratório (Castro et al. 2003).

A avaliação se deu aos 30 dias: 9 plantas apresentaram-se resistentes ao herbicida comparativamente aos respectivos controles (matriz) que se apresentaram cloróticos (Figura 24). 

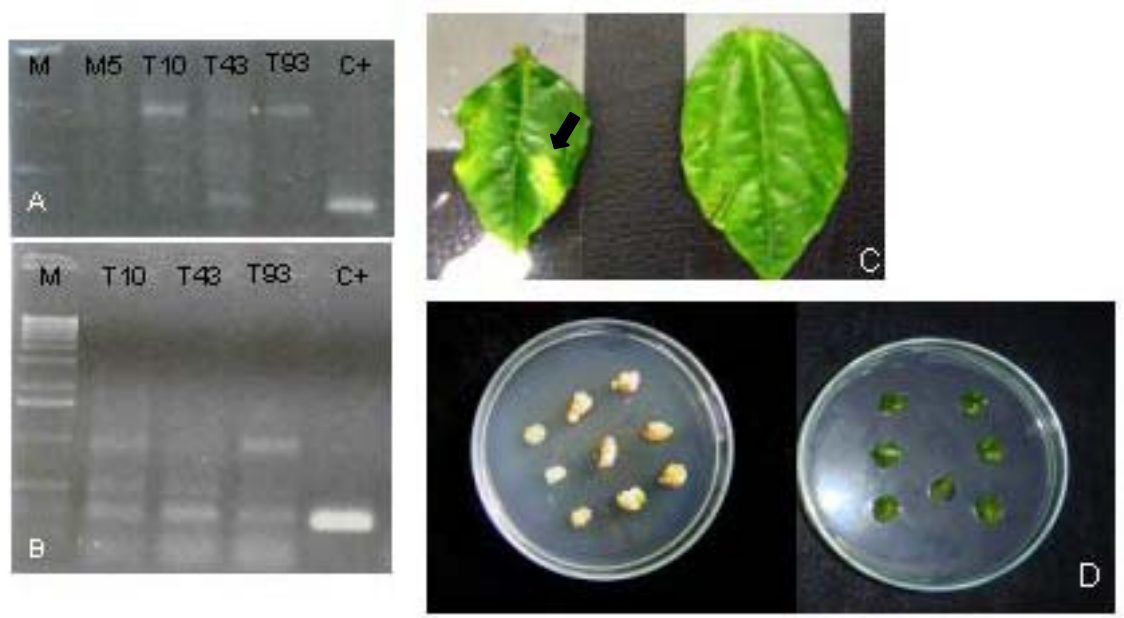

Figura 24 - Prova molecular da expressão do gene att A em plantas transgênicas de maracujá por RT-PCR (A) e (B): T10, T43 e T93 apresentam a banda de $\sim 300 \mathrm{pb}$ referente a parte do gene att $A$. M5 corresponde à planta matriz e $\mathrm{C}+$ ao DNA do gene att $\mathrm{A}$ clonado em pCattA 3300; $\mathrm{M}=$ Ladder $1 \mathrm{~kb}$. (C): Prova de resistência à Xanthomonas axonopodis pv. passiforae, à esquerda, folha destacada da planta matriz apresentando a lesão (seta) e à direita, da planta transgênica. (D): Prova de resistência à fosfinotricina, à esquerda, discos susceptíveis ao herbicida e à direita, discos da planta transgênica.

\subsection{Resumo dos resultados, biossegurança e perspectivas}

A Tabela 8 apresenta um resumo dos resultados aqui obtidos de transformação de maracujá amarelo via $A$. tumefaciens sobre as análises da integração do gene (PCR), expressão (RT-PCR), resistência à bacteriose e ao agente seletivo, e quanto à eficiência de transformação de explantes foliares e hipocotiledonares de maracujá amarelo var. FB-100. Cabe salientar que as plantas resistentes ao herbicida são as mesmas plantas sem lesão foliar e RTPCR+, o que confirma a integração da seqüência completa (entre as bordas do T-DNA) nessas plantas. Isso constitui em uma vantagem agronômica 
importante, pois possibilita o uso do herbicida em plantas comerciais de maracujá amarelo, desde que as normas de biossegurança sejam atendidas.

Foram obtidas plantas de maracujá amarelo expressando o gene att $A$ constitutivanente, ou seja, em todos os tecidos da planta. Esta proteína é bactericida e seu principal alvo são bactérias Gran-negativas. Isto pode ser prejudicial para a comunidade bacteriana endofítica, pois pode causar a eliminação de outras bactérias sensíveis, favorecendo o crescimento de outros microorganismos (Azevedo \& Araújo, 2003). Heuer \& Smalla (1999) avaliaram a comunidade bacteriana da filosfera de plantas transgênicas de batata contendo o transgene que expressa a lisozima. Esta enzima é bactericida, tornando a planta mais resistente a patógenos. Os autores observaram um aumento da colonização da planta por bactérias do grupo Erwinia sp. e uma redução de Agrobacterium e bactérias Gram-positivas.

Outro aspecto importante está relacionado ao produto comercial da planta de maracujá, que é o fruto. A presença da proteína bactericida no fruto, que é consumido in natura ou usado para suco, deve ser alvo de testes para evitar risco à população. Mesmo que a atacina $A$ não apresente evidências de toxicidade em humanos, seria importante restringir sua expressão apenas a locais específicos como tecidos verdes, por exemplo.

Uma maneira de contornar esses problemas seria o uso de promotores induzíveis, que limitam a expressão do gene ao momento e local da infecção apenas. Diversos genes, cuja expressão é induzida pela presença de patógenos, já são conhecidos e seus promotores estão sendo estudados (Pompermayer, 2004 e referências). Outra alternativa seria o uso de promotores sintéticos que contêm elementos chaves de promotores induzidos pelo patógeno (Rushton et al., 2002). Existem várias seqüências depositadas no GenBank NCBI de promotores induzidos pela presença de patógenos, principalmente de Arabidopsis, bem caracterizados.

Esta tese indica que é a transgenia é uma alternativa viável para a cultura do maracujá. Sugerem-se resolver, com urgência, questões relativas à 
biossegurança visando à liberação de um produto. Mas, sem dúvida, um grande avanço foi alcançado: os protocolos de transformação foram otimizados e foi demonstrada a ação favorável do gene att A no controle da bacteriose do maracujazeiro. 
Tabela 8. Sumário dos ensaios de transformação de maracujá amarelo via $A$. tumafaciens contendo o plasmídeo pCattA3300: análise molecular por PCR, expressão gênica por RT-PCR e de resistência de à bacteriose e ao agente seletivo, o herbicida fosfinotricina

\begin{tabular}{|c|c|c|c|c|c|c|c|c|c|}
\hline Tipo de explante & $\begin{array}{l}\text { Explantes } \\
\text { inoculados }\end{array}$ & $\begin{array}{l}\text { Explantes } \\
\text { cultivados }\end{array}$ & $\begin{array}{l}\text { Explantes } \\
\text { com brotos }\end{array}$ & $\begin{array}{c}\text { Brotos } \\
\text { regenerados }\end{array}$ & $\begin{array}{l}\text { Brotos } \\
\text { PCR+ }\end{array}$ & $\begin{array}{c}\text { Plantas } \\
\text { RT-PCR+ }\end{array}$ & $\begin{array}{l}\text { Plantas sem } \\
\text { lesão foliar }\end{array}$ & $\begin{array}{c}\text { Plantas } \\
\text { resistentes ao } \\
\text { herbicida }\end{array}$ & $\begin{array}{c}\text { Eficiência de } \\
\text { Transformação† }\end{array}$ \\
\hline FOLIAR & 67 & $\begin{array}{c}19^{*} \\
(28,4)\end{array}$ & $\begin{array}{c}8 \\
(42,1)\end{array}$ & 10 & $\begin{array}{c}4 \\
(40,0)\end{array}$ & 1 & 1 & 1 & 5,9 \\
\hline Hipocotiledonar & 246 & $\begin{array}{c}246^{* *} \\
(100,0)\end{array}$ & $\begin{array}{c}165 \\
(67,1)\end{array}$ & 162 & $\begin{array}{c}27 \\
(16,7)\end{array}$ & 2 & 9 & 8 & 10,9 \\
\hline Total & 313 & 265 & 193 & 172 & 31 & 3 & 10 & 9 & 9,9 \\
\hline
\end{tabular}

Entre parênteses estão valores em percentagem

*sob seleção pelo herbicida; ** sem seleção

†Eficiência de transformação = número de brotos PCR+/número de explantes inoculados x 100 


\section{CONCLUSÕES}

A transformação de protoplastos derivados de tecido cotiledonar de maracujá amarelo é viável por eletroporação; para a seleção das microcolônias transformadas, recomenda-se o uso de higromicina $(8,0 \mathrm{mg} / \mathrm{L})$ ou fosfinotricina $(0,3 \mathrm{mg} / \mathrm{L})$;

A resposta morfogênica dos explantes hipocotiledonares de maracujá amarelo é mais acentuada comparativamente à dos explantes foliares e cotiledonares em termos de formação de gemas e brotos.

O procedimento mais adequado para a transformação de maracujá amarelo é aquele mediado por Agrobacterium tumefaciens; taxas da ordem de 6 e $11 \%$ de brotos transgênicos são obtidas a partir da infecção de explantes foliares e hipocotiledonares, respectivamente.

A atacina A, originária da mariposa Trichoplusia ni, é secretada para o meio extracelular em plantas, e é capaz de inibir o avanço das lesões provocadas pela bactéria Xanthomonas axonopodis pv. passiflorae em folhas destacadas de brotos transgênicos de maracujá amarelo. 


\section{REFERÊNCIAS}

ALMEIDA, W.A.B. Caracterização anatômica da organogênese in vitro e transformação genética via Agrobacterium tumefaciens em Citrus sp. Piracicaba, 2002. 138p. Tese (Doutorado) - Escola Superior de Agricultura "Luiz de Queiroz", Universidade de São Paulo.

ALMEIDA, W.A.B.; MOURÃO FILHO, F.A.A.; PINO, L.E.; BOSCARIOL, R.L.; RODRIGUEZ A.P.M.; MENDES, B.M.J. Genetic transformation and plant recovery from mature tissues of Citrus sinensis L. Osbeck. Plant Science, v. 164, p. 203- 211, 2003.

ALVES, A.C. Estudos anatômicos da organogênese in vitro de soja e otimização do processo de transformação via Agrobacterium tumefaciens. Piracicaba, 1999. 92p. Dissertação (Mestrado) - Escola Superior de Agricultura "Luiz de Queiroz", Universidade de São Paulo.

ANDO, K.; OKADA, M.; NATORI, S. Purification of sarcotoxin II, antibacterial proteins of Sarcophaga peregrina (flesh fly) larvae. Biochemistry, v.26, p.226-230, 1987.

ANDRADE, G.M.; SARTORETTO, L.M.; BRASILEIRO, A.C.M. Biologia molecular do processo de infecção por Agrobacterium spp. Fitopatologia Brasileira, v. 28, p. 465-476, 2003.

ANZAI, H.; YONEYAMA, K.; YAMAGUCHI, I. Transgenic Tobacco Resistant to a Bacterial Disease by Detoxification of a Pathogenic Toxin. Molecular and General Genetics, v. 219, p. 492-494, 1989. 
APPEZZATO-DA-GLORIA, B.; VIEIRA, M.L.C.; DORNELAS, M.C. Anatomical studies of in vitro organogenesis induced in leaf-derived explantes of passionfruit. Pesquisa Agropecuária Brasileira, v.34, p.2007-2013, 1999.

ARAGAO, F. J. L.; GROSSI DE SA, M. F.; DAVEY, M. R.; BRASILEIRO, A. C. M.; FARIA, J. C.; RECH, E. L. Factors influencing transient gene expression in bean (Phaseolus vulgaris L.) using an electrical particle acceleration device. Plant Cell Reports, v.12, p.483-490, 1993.

ARAGÃO, F.J.L.; BARROS, L. M.G.; BRASILEIRO, A.C.M.; RIBEIRO, S.G.; SMITH, F.D.; SANFORD, J.C.; FARIA, J.C.; RECH, E.L. Inheritance of foreign genes in transgenic bean (Phaseolus vulgaris L.) co-transformed via particle bombardment. Theoretical and Applied Genetics, v.152, p.120134, 1996.

ARAGÃO, F.J.L.; Development of transformation methods toward producing transgenic plants with abiotic stress tolerance. JIRCAS Working Report. p. 35-42, 2002.

ARAGÃO, F.J.L.; VIANNA, G.R.; ALBINO, M.M.C.; RECH, E.L. Transgenic dry bean tolerant to the herbicide glufosinate ammonium. Crop Science, v. 42, p. $1298-13022002$.

ASANO, Y.; ITO, Y.; FUKAMI, K.; FUJIIE, A. Herbicide-resistant transgenic creeping bentgrass plants obtained by electroporation using an altered buffer. Plant Cell Reports, v. 17, p. 963-967, 1998.

AZEVEDO J.L; ARAUJO, W.L. Genetically modified crops: environmental and human health concerns. Mutation Research, v. 544, p. 223-233, 2003.

AZEVEDO, J.L.; FUNGARO, M. H. P., VIEIRA, M. L. C. Transgênicos e evolução dirigida. História, Ciências, Saúde, v. 7, p. 452-464, 2000.

BARBOSA, L.S. Resistência de Passiflora spp. a Xanthomonas campestris pv. passiflorae e detecção do patógeno em sementes. Viçosa, 1995, 66p Dissertação (Mestrado) - Universidade Federal de Viçosa. 
BECERRA, D.C.; FORERO, A.P.; GÓNGORA, G.A. Age and physiological condition of donor plants affect in vitro morphogenesis in leaf explants of Passiflora edulis f. flavicarpa. Plant Cell, Tissue and Orgnan Culture, v. 79, p. 87-90, 2004.

BEJARANO, E.R.; LICHTENSTEIN, C.P. Expression of TGMV antisense RNA in transgenic tobacco inhibits replicatio0n of BCTV but not ACMV geminiviruses. Plant Molecular Biology, v. 24, p. 241-248, 1994.

BENNETT, P.M.; LIVESEY, C.T.; NATHWANI, D.; REEVES, D.S.; SAUNDERS, J.R.; WISE R. An assessment of the risks associated with the use of antibiotic resistance genes in genetically modified plants: report of the Working Party of the British Society for Antimicrobial Chemotherapy . Journal of Antimicrobial Chemotherapy, v. 53, p. 418-431, 2004.

BENT, A.F. Plant Disease Resistance Genes: Function Meets Structure Plant Cell. Plant Cell, v. 8, p. 1757-1771, 1996.

BIASI, L.A.; FALCO, M.C.; RODRIGUEZ, A.P.M.; MENDES, B.M.J. Organogenesis from internodal segments of yellow passion fruit. Scientia Agricola, v.57, p.661-665, 2000.

BIRCH, R.G. Plant transformation: Problems and Strategies for pratical application. Annual Review of Plant Phytopathology and Plant Molecular Biology, v. 48, p. 297-326, 1997.

BOEVINK, P.; MARTIN, B.; OPARKA, K.; SANTA CRUZ, S.; HAWES, C. Transport of virally expressed green fluorescent protein through the secretory pathway in tobacco leaves is inhibited by cold shock and brefeldin A. Planta, v. 208, p. 392-400, 1999.

BOGS, J. BRUCHMüLLER, I.; ERBAR, C.; GEIDER, K. Colonization of host plants by the fire blight pathogen Erwinia amylovora marked with genes for bioluminescence and fluorescence. Phytopathogy, v.88, p.416-421, 1998. 
BOMAN, H.G.; FAYE, I.; GUDMUNDSSON, G.H.; LEE, J-Y.; LIDHOLM, D-A. Cell-free immunity in Cecropia. European Journal of Biochemistry, v.201, p.23-31, 1991.

BOMAN, H.G.; HULTMARK, D. Cell-free immunity in insects. Annual Review Microbiology, v.41, p.103-126, 1987.

BONAS, U.; VAN DEN ACKERVEKEN, G. Recognition of bacterial avirulence proteins occurs inside the plant cell: a general phenomenon in resistance to bacterial diseases. Plant Journal, v. 12, p. 1-7, 1997.

BOND, J.E.; ROOSE, M.L. Agrobacterium-mediated transformation of the commercially important citrus cultivar Washington navel orange. Plant Cell Reports, v.18, p.229-234, 1998.

BOREM, A; DEL GIÚDICE, M.P.; SAKIYAMA, N.S.; SEDIYAMA, T.; MOREIRA, M.A; PORTUGAL, R.S. (Ed). Biossegurança, proteção de cultivares, acesso aos recursos genéticos e propriedade intelectual na agropecuária, Viçosa: UFV, 1998. 182p.

BOSCARIOL, R.L. Transformação genética de laranja doce (Citrus sinensis I. Obseck) com a gene atacinaA. Piracicaba, 2004. 137p. Tese (Doutorado) Centro de Energia Nuclear Aplicado à Agricultura, Universidade de São Paulo.

BOSCARIOL, R.L.; MONTEIRO, M.; CHABREGAS, S.M.; VIEIRA, M.L.C.; TAKAHASHI, E.K.; VIEIRA, L.G.E.; PEREIRA, L.F.P.; BELASQUE JUNIOR, J.; DALLAPRIA, M.; CHRISTIANO, R.S.C.; BERGAMIN FILHO, A.; MOURÃO FILHO, F.A.A.; MENDES B.M.J. Expression of the attacin A gene from Tricloplusia ni reduces susceptibility to Xanthomonas axonopodis pv. Citri in Citrus sinensis cv. Hamlin. Transgenic Research/submetido/ 
BRANDIZZI, F.; IRONS, S.L.; JOHANSEN, J.; KOTZER, A.; NEUMANN, U. GFP is the way to glw: bioimaging od the plant endomembrane system. Journal of Microscopy, v. 214, p. 138-158, 2004.

BRASILEIRO, A.C.M.; CARNEIRO, V.T. de C. Manual de transformação genética de plantas. Brasília: Embrapa-SPI/Embrapa-Cenargen, 1998. $309 p$.

BRASILEIRO, A.C.M.; DUSI, D.M.A. Transformação genética de plantas In: TORRES, A.C. CALDAS, L.S.; BUSO, J.A. Cultura de tecidos e transformação de plantas. Brasília: EMBRAPA-SP/EMBRAPA CNPH, 1999,p. 679-735.

BRAZ, A.S.K. Clonagem e seqüenciamento dos genes da proteína capsidial e da replicase de um Potyvirus causador de endurecimento dos frutos do maracujazeiro, e transformação de maracujá-amarelo com construção derivada desses genes. Viçosa, 1999. 106p. Dissertação (Mestrado) Universidade Federal de Viçosa.

CARLSON, P. S.; SMITH, H. H.; DEARING, R. D. Parasexual interespecific plant hybridization. Proceeding National Academic Science U.S.A., v.69, p.2292-2294, 1972.

CARLSSON, A., NYSTRÖM, T., COCK, H. de; BENNICH, H. Attacin - an insect immune protein - binds LPS and triggers the specific inhibition of bacterial outer-membrane protein synthesis. Microbiology, v. 144, p. 2179-2188, 1998.

CARLSSON, A.; ENGSTROM, P.; PALVA, E. T.; BENNICH, H. Attacin, an antibacterial protein from Hyalophora cecropia, inhibits synthesis of outer membrane proteins in Escherichia coli by entering with omp gene transcription. Infect Immunology, v.59, p.3040-3045, 1991.

CARMONA, M.J.; MOLINA, A.; FERNÁNDEZ, J.A.; LÓPEZ-FANDO, J.; GARCIA-OLMEDO, F. Expression of the -thionin gene from barley in tobacco confers enhanced resistance to bacterial pathogens. Plant Journal, v. 3, p. 457-462, 1993. 
CARR, J.P.; DIXON, D.C.; NIKOLAU, B.J.; VOELKERDING, K.V.; KLESSIG, D.F. Synthesis and localization of pathogenesis-related proteins in tobacco. Molecular Cell Biology, v. 7, p. 1580-1583, 1987.

CASTEELS, P.; AMPE, C.; JACOBS, F.; VAECK , M.; TEMPST, P. Apidaecins: antibacterial peptides from honeybees. The EMBO Journal, v. 8, p.23872391, 1989.

CASTRO, AP.; TAKAHASHI, EK.; MONTEIRO, M; MATTA, FP.; CAMPOS, MRC.; VIEIRA, MLC. Obtenção, seleção in vitro e avaliação de plantas transgênicas de maracujá quanto à resistência à bacteriose.In: CONGRESSO BRASILEIRO DE GENÉTICA, 49., Águas de Lindóia. 2003. Resumo, Águas de Lindóia: SBG, 2003.

CHABREGAS, S.M. Caracterização da localização subcelular da proteina THI1 de Arabidopsis thaliana Piracicaba, 2001. 92p. Tese (Doutorado) - Escola Superior de Agricultura “Luiz de Queiroz”, Universidade de São Paulo.

CHABREGAS, S.M.; LUCHE, D.D.; FARIAS, L.P.; RIBEIRO, A.F.; VAN SLUYS, M.-A.; MENCK, C.F.M.; SILVA-FILHO, M.C. (2001). Dual targeting properties of the N-terminal signal sequence of Arabidopsis thaliana THI1 protein to mitochondria and chloroplasts. Plant Molecular Biology, v. 46, p. 639 -650, 2001.

CHEN, F-C.; KUEHNLE, A.R. Obtaining transgenic Anthurium through Agrobacterium mediated transformation of etiolated internodes. Journal of de American Society for Horticultural Science, v.121, p.47-51, 1996.

COCKING, E.C. A method for isolation of plant protoplasts and vacuoles. Nature, v.187, p.927-929, 1960.

COOPER, B.Genetic mechanisms for engineering host resistance to plant viruses. In: BELLOWS, T.S.; FISHER, T.W. (Eds.). Handbook of Biological Control, Academic Press, San Diego, California. 1999. p.557574. 
COYNE, D.P.; SCHUSTER, M.L. Genetics of and breeding for resistance to bacterial pathogens in vegetable crops. HortScience, v. 18, p. 30-36, 1983.

CRUZ-HERNANDEZ, A., WITJAKSONO, J., LITZ, R.E., GOMEZ-LIM, M. Agrobacterium tumefaciens-mediated transformation of embryogenic avocado cultures and regeneration of somatic embryos. Plant Cell Reports, v. 17, p. 497-503, 1998.

D"HALLUIN, K.; BONNE, E.; BOSSUT, M.B.; LEEMANS, J. Transgenic maize plants by tissue electroporation. Plant Cell, v. 4, p. 1495-1505, 1992.

DE BLOCK, J.; BOTTERMAN, J.; VANDEWIELE, M.; DOCKX, J.; THOEN, C.; GOSSELE, V.; RAO MOVVA, N.; THOMPSON, C.; VAN MONTAGU, M.; LEEMANS, J. Engineering herbicide resistance in plants by expression of a detoxifying enzyme. EMBO Journal, v.6, p.2513-2518, 1987.

DE BLOCK, M. The cell biology of plant transformation: current state, problems, prospects and the implications for plant breeding. Euphytica, v. 71, p. 1-14, 1993.

DE LA RIVA, G.A.; GONZALEZ-CABRERA, J.; VAZQUEZ-PADRÓN, R.; AYRAPADRO, C. Agrobacterium tumefaciens: a natural tool for plant transformation. Eletronic Journal of Biotechnology, v. 1, p. 1-16, 1998.

DE WIT, P.J.G.M. Molecular characterization of gene-for-gene systems in plantfungus interactions and the application of avirulence genes in control of plant pathogens. Annual Review of Phytopathology, v. 30, p. 391-418, 1992.

DHIR, S.K.; DHIR, S.; HEPBURN, A.; WIDHOLM. J.M. Factors affecting transient gene expression in electroporated Glycine max protoplasts. Plant Cell Reports, v. 10, p. 106-110, 1991.

DIAS, M.S.C. Principais doenças fúngicas e bacterianas do maracujazeiro. Informe Agropecuário, v. 21, p. 34-38, 2000.

DICKINSON, L.; RUSSEL, V.; DUNN, P. E. Family of bacteria-regulated, cecropin D-like peptides from Manduca sexta. Journal of Biology Chemistry, v.263, p.19424-19429, 1988. 
DORNELAS, M.C.; TAVARES, F.C.A.; OLIVEIRA, J.C.; VIEIRA, M.L.C. Plant regeneration from protoplast fusion in Passiflora spp. Plant Cell Reports, v.15, p.106-110, 1995.

DORNELAS, M.C.; TAVARES, F.C.A.; VIEIRA, M.L.C. Plant regeneration from protoplast fusion in Passiflora spp. Plant Cell Reports, v.15, p.106-110, 1995.

DORNELAS, M.C.; VIEIRA, M.L.C. Tissue culture studies on species of Passiflora. Plant Cell, Tissue and Organ Culture, v. 36, p. 211-217, 1994.

DORNELAS, M.C.; VIEIRA, M.L.C. Tissue culture studies on species of Passiflora. Plant Cell, Tissue and Organ Culture, v.36, p.211-217, 1994.

DORNELAS, M.C.; VIEIRA, M.L.C.. Plant regeneration from protoplast cultures of Passiflora edulis var. flavicarpa Deg., P. amethystina Mikan. and $P$. cincinnata Mast. Plant Cell Reports, v. 13, p. 103-106, 1993.

DROGE, M.; PUEHLER, A.; SELBITSCHKA, W. Horizontal gene transfer as a biosafety issue: a natural phenomenon of public concern. Journal of Biotechnology, v. 64, p. 75-90, 1998.

DUMAS, E.; LHERMINIER, J.; GIANINAZZI, S.; WHITE, R. F.; ANTONIW, J. F. Immunocytochemical localization of pathogenesis-related $b_{1}$ protein induced in tobacco mosaic virus-infected or polyacrylic acid-treated tobacco plants. Journal Genetics Virology, v. 69, p. 2687-2694, 1998.

DUNWELL, J.M. Transgenic approaches to crop improvement. Journal of Experimental Botany, v.51, p.487-496, 2000.

DURING, K,; PORSCH, P.; FLADUNG, M.; LÖRZ, H. Transgenic potato plants resistant to the phytopathogenic bacterium Erwinia carotovora. Plant Journal, v. 3, p. 587-598, 1993.

DÜRING, K. Genetic engineering for resistance to bacteria in transgenic plants by introduction of foreign genes. Molecular Breeding, v.2, p.297-305, 1996. 
D'ÚTRA VAZ, F.B.; SANTOS, A.V.P. DOS; MANDERS, G.; COCKING, E.C.; DAVEY, M.R; POWER, J.B. Plant regeneration from leaf mesophyll protoplasts of the tropical woody plant, passionfruit (Passiflora edulis fv. flavicarpa Degener): the importance of the antibiotic cefotaxime in the culture medium. Plant Cell Reports, v. 12, p. 220-225, 1993.

EDWARDS, K.; JOHNSTONE, C.; THOMPSON, C. A simple and rapid method for the preparation of plant genomic DNA for PCR analysis. Nucleic Acid Research, v.19, p.1349, 1991.

EMBRAPA - Reunião Técnica: Pesquisa em maracujazeiro no Brasil. Cruz das Almas: CNPMF, 1998, 53p. (Documento, 77).

ENGSTRÖM, P., CARLSSON, A., ENGSTRÖM, A., TAO, Z.-J.; BENNICH, H. The antibacterial effect of attacins from the silk moth Hyalophora cecropia is directed against the outer membrane of Escherichia coli. EMBO Journal, v.3, p.3347-3351, 1984.

EPPLE, P.; APEL, K.; BOHLMANN, H. Over expression of an endogenous thionin enhances resistance of Arabidopsis against Fusarium oxysporum. Plant Cell, v.9, p. 509-520, 1997.

FERNANDO, J.A.; MACHADO, S.R.; VIEIRA, M.L.C.; APPEZZATO-daGLORIA, B. Ultra estrutura da organogênese in vitro de Passiflora edulis Sims. f. flavicarpa Deg. (compact disc). In. CONGRESSO DA SOCIEDADE BOTÂNICA SÃO PAULO, 15., Ubatuba, 2004. Resumos. Ubatuba: SBSP, 2004.

FISCHHOFF, D. A.; BOWDISH, K. S.; PERLAK, F. J.; MARRONE, P. G.; McCORMICK, S. M.; NIEDERMEYER, J. G.; DEAN, D. A.; KUSANOKRETZMER, K.; MAYER, E. J.; ROCHESTER, D. E.; ROGERS, S. G.; FRALEY, R. T. Insect tolerant transgenic tomato plants. Bio/Technology, v. 5, p. $807-813,1987$. 
FITCH, M.M.; MANSHARDT, R.M.; GONSALVES, D.; SLIGHTOM, J.L.; SANFORD, J.C. Virus resistant papaya plants derives from tissues bombarded with the coat protein gene papaya ringspot virus. BioTechnology, v. 10, p. 1466-1472, 1992.

FLORACK, D., ALLEFS, S., BOLLEN, R., BOSCH, D., VISSER, B., STIEKEMA, W.. Expression of giant silkmoth cecropin $B$ genes in tobacco. Transgenic Research, v.4, p.132-141, 1995.

FLYG, C.; DALHAMAR, G.; RASMUSOM, B.; BOMAN, H. G. Insect immunity: inducible antibacterial activity in Drosophila melanogaster. Innsect Biochemistry, v. 17 , p. 153-160. 1986

FNP CONSULTORIA \& AGROINFORMATIVOS. Agrianual 2004: Anuário de Agricultura Brasileira. São Paulo, 2004. p. 359-365.

FREARSON, E.M.; POWER, J.B.; COCKING E.C. The isolation, culture and regeneration of Petunia leaf protoplasts. Developmental Biology, v. 33, p. 130-137, 1973.

FROMM, M.E.; TAYLOR, L.P.; WALBOT, V. Stable transformation of maize after gene transfer by electroporation. Nature, v. 319, p. 791-793, 1986.

FRUTOS, R.; RANG, C.; ROYER, M. Managing insect resistance to plants producing bacillus thuringiensis toxins. Critical Reviews in Biotechnology, v. 19, p. 227-276, 1999.

FUNGARO, M.H.P.; VIEIRA, M.L.C. Protoplastos de plantas: isolamento e regeneração. Ciência e Cultura, v. 4, p.1151-1159, 1989.

GALUN, E.; BREIMAN, A. Transgenic plants. London: Imperial College Press. 1997. 376p.

GAMBORG, O.L.; MILLER, R.A.; OJIMA, K. Nutrient requirements of suspension culture of soybean roots cells. Experimental Cell Research, v. 50 , p. 151-158, 1968.

GELVIN, S.B. Agrobacterium and plant genes involved in T-DNA transfer and integration. Annual Review of Plant Physiology Plant Molecular Biology, v. 51, p. 223-256, 2000. 
GELVIN, S.B. Agrobacterium-mediated plant transformation: The biology behind the "gene-jockeying" tool. Microbiology and Molecular Biology Reviews, v. 67, p. 16-37,2003.

GILMOUR, D.M.; DAVEY, M.R.; COCKING, E.C. Production of somatic hybrid tissues following chemical and eletrical fusion of protoplasts from albino cell suspensions of Medicago sativa and M. borealis. Plant Cell Reports, v. 8, p. 29-32, 1989.

GONZALEZ, E.R. Transformação genética de Eucalyptus grandis e do híbrido E. grandis x E. urophylla via Agrobacterium Piracicaba, 2002. 93p. Tese (Doutorado) - Escola Superior de Agricultura "Luiz de Queiroz", Universidade de São Paulo.

GROVER, A.; GOWTHAMAN, R. Strategies for developmente of fungusresistant transgenic plants. Current Science, v. 84, p.330-340, 2003.

HADIDI, A.; KHETARPAL, R.K.; KOGANEZAWA, H. Plant Virus Disease Control, St. Paul, Minnesota: APS Press. 1998. 684p.

HALDRUP, A.; PETERSEN, S. G.; OKKELS F.T. The xylose isomerase gene from Thermoanaerobacterium thermosulfurogenes allows effective selection of transgenic plant cells using D-xylose as the selection agent. Plant Molecular Biology, v. 37, p. 287-296, 1998b.

HALDRUP, A.; PETERSEN, S.G.; OKKELS, F.T. Positive selection: A selecrion principle based on xylose isomerase, an enzyme used in the food industry. Plant Cell Reports, v. 18, p. 76-81, 1998a.

HALFORD, N. Prospects for genetically modified crops. Annual Applied Biology, v. 145, p. 17-24, 2004.

HALL, R.M.; DREW, R.A.; HIGGIN, C.M.; DIETZGEN, R.G. Efficient organogenesis of na Australian passionfruit hybrid (Passiflora edulis $\mathrm{x}$ Passiflora edulis var. flavicarpa) suitable for gene delivery. Australian Journal of Botany, v.48, p.673-680, 2000.

HANAHAN, D. Studies on the transformation of Escherichia coli with plasmids. Journal of Molecular Biology, v.166, p.557-580, 1983. 
HE, Z.; FU, Y.; SI, H.; HU, G.; ZHANG, S.; YU, Y.; SUN, Z. Phosphomannoseisomerase $(p m i)$ gene as a selectable marker for rice transformation via grobacterium. Plant Science, v. 166, p.17-22, 2004.

HELGESON, J. P. Postharvest resistance through breeding and biotechnology. Phytopatology, v. 79, p. 1375-1377, 1989.

HELLWALD, K-H.; PALUKAITIS, P. Viral RNA serves as a potential target for two independent mechanisms of replicase-mediated resistance against cucumber mosaic virus. Cell, v. 83, p. 937-946, 1995.

HEUER, H.; SMALLA, K. Bacterial phyllosphere communities of Solanum tuberosum L. and T4 lysozyme-producing transgenic variants. FEMS Microbiology Ecology, v. 28, p. 357-371, 1999.

HOEKEMA, A.; HIRSCH, P.R.; HOOYKAAS, P.J.J.; SCHILPEROORT, R.A.A Binary plant vector strategy based on separation vir and T-region of Agrobacterium tumefaciens Ti-plasmid. Nature, v.303, p.179-180, 1983.

HOFFMANN, L.V.; VIEIRA, M.L.C.; Resposta in vitro e suscetibilidade ao Agrobacterium de duas cultivares de Stylosanthes guianensis. Pesquisa Agropecuária Brasileira, v.35, p.733-742, 2000.

HOOD, E.E.; GELVIN, S.B.; MELCHERS, L.S.; HOEKEMA, A. New Agrobacterium helper plasmids for gene transfer into plants. Transgenic Research, v.2, p.208-218, 1993.

HOSOKAWA, D.; OHASHI, Y. Immunochemical localization of pathogenesisrelated proteins secreted into the intercellular spaces of salycilate-treated tobacco leaves. Plant Cell Physiology, v. 29, p. 1035-1040, 1988.

HUANG, Y.; NORDEEN, R.O.; DI, M.; OWENS, L.D.; McBEATH, J.H. Expression of an engineered cecropin gene cassette in transgenic tobacco plants confers disease resistance to Pseudomonas syringae pv. tabaci. Phytopathology, v.87, p.494-499, 1997.

HULTMARK, D. Immune reactions in Drosophila and other insects: a model for innate immunity. TRENDS in Genetics, v.9, p.178-183, 1993. 
HULTMARK, D.; ENGSTROM, A.; ANDERSSON, K.; STEINER, H.; BENNICH, H.; BOMAN, H. G. Insect immunity. Attacins, a family of antibacterial proteins from Hyalophora cecropia. EMBO Journal, v.2, p.571-576, 1983.

HULTMARK, D.; STEINER, H.;RASMUSON, T.; BOMAN, H. G. Insect immunity: purification and properties of three inducible bactericidal proteins from hemolymph of immunized pupae of Hyalophora cecropia. European Journal Biochemistry, v.106, p.7-16, 1980.

ISUTSA, D.K. Rapid micropropagation of passion fruit (Passiflora edulis Sims.) varieties. Scientia Horticulturae, v. 99, p. 395-400, 2004.

JAMES, D.J., PASSEY, A.J., BARBARA, D.J., BEVAN, M. Genetic transformation of apple (Malus pumila Mill.) using a disarmed Ti-binary vector. Plant Cell Reports, v. 7, p. 658-661, 1989.

JAYNES, J.M.; NAGPALA, P.; DESTEFANO-BELTRAN, L.; HONG-HUNG, J.; KIM, J.; DENNY, T.; CETINER, S. Expression of a cecropin B lytic peptide analogue in transgenic tobacco confers enhanced resistance to bacterial wilt caused by Pseudomonas solanacearum. Plant Science, v.8, p.43-53, 1993.

JAYNES, J.M.; XANTHOPOULOS, K.G.; DESTÉFANO-BELTRÁN, L.; DODDS, J.H. Increasing bacterial disease resistance in plants utilizing antibacterial genes from insects. Bioessays, v.6, p.263-270, 1987.

JOERSBO, M.; DONALDSON, I.; KREIBERG, J.; PETERSEN, S.G.; BRUNSTEDT, J.; OKKELS, F.T. Analysis of mannose selection used for transformation of sugar beet. Molecular Breeding, v. 4, p. 111-117, 1998.

KANEYOSHI, J.; KOBAYASHI, S.; NAKAMURA, Y.; SHIGEMOTO, N.; DOI, Y. A simple and efficient gene-transfer system of trifoliate orange (Poncirustrifoliata raf). Plant Cell Reports, v. 13, p. 541-545, 1994.

KANG, D., LUNDSTRÖM, A.; STEINER, H. Trichoplusia ni attacin A, a differentially displayed insect gene coding for an antibacterial protein. Gene, v.174, p.245-249, 1996. 
KANG, D.; LUNSTROM, A.; STEINER, H. trichoplusa ni attacinA, a differentially displayed insect gene coding for an antimicrobial protein. Gene, v. 174, p. 245-249, 1996.

KANTHARAJAH, A.S.; DODD, W.A. In vitro micropropagation of Passiflora edulis (Purple passion fruit). Annals of Botany, v.65, p.337-339, 1990.

KAO, K.N. Chromosomal behavior of somatic hybrids of soybean x Nicotiana glauca. Molecular General Genetics, v. 150, p. 225-230, 1977.

KAO, K.N.; MICHAYLUK, M.R.. Nutritional requirements for growth of Vicia hajastana cells and protoplasts at a very low density in liquid media. Planta, v. 126, p. 105-110, 1975.

KARNOVSKY, M.J. A formaldehyde-glutaraldehyde fixative of high osmolarity for use electron microscopy. Journal of Cell Biology, v.27, p.137-138, 1965.

KIKKERT, J.R.. The Biolistic PDS-1000/He device. Plant, Cell, Tissue, and Organ Culture, v. 33, p. 221-226, 1993.

KISAKA, H.; SANO, H.; KAMEYA, T. Characterization of transgenic rice plants that express rgp1, the gene for a small GFP-binding protein from rice. Theoretical Applied Genetics, v. 97, p. 810-815, 1998.

KO, K.; NORELLI, J.L.; REYNOIRD, J-P; BORESJZA-WYSOCKA, E.; BROWN, S.K.; ALDWINCKLE, H.S. Effect of untranslated leader sequence of AMV RNA 4 and signal peptide of pathogenesis-related protein $1 \mathrm{~b}$ on attacin gene expression, and resistance to fire blight in transgenic apple. Biotechnology Letters, v.22, p.373-381, 2000.

KOHLI, A.; TWYMAN, R.M.; ABRANCHES, R.; WEGEL, E.; STOGER, E.; CHRISTOU P. Transgene integration, organization and interaction in plants. Plant Molecular Biology, v. 52, p. 247-258, 2003. 
KOMBRINK, E.; SOMSSICH, I.E. Defense responses of plants to pathogens. Advances in Botanical Research, v. 21, p.1-34, 1995.

KOSUGI, S.; OHASHI, Y.; NAKAJIMA, K.; ARAI, Y.; An improved assay for $\beta$ glucuronidase in transformed cells: methanol almost completely suppresses a putative endogenous $\beta$-glucuronidase activity. Plant Science, v.70, p.133-140, 1990.

KOZIEL, M.G.; BELAND, G.L.; BOWMAN, C. Field performance of elite transgenic maize plants expressing an insecticidal protein derived from Bacillus thuringiensis. Bio/Tecnology, v.11, p.194-200, 1993.

KUCHUK, N.; KOMARNITSKI, I.; SHAKHOVSKY, A.; GLEBA, Y. Genetic transformation of Medicago species by Abrobacterium tumefaciens and electroporation of protoplasts. Plant Cell Reports, v. 8, p. 660-663, 1990.

KUMAR, P.P.; LAKSHMANAN, P.; THORPE, T.A. Regulation of morphogenesis in plant tissue culture by ethylene (Review article). In Vitro Cellular and Developmental Biology-Plant, v. 34, p. 94-103, 1998.

LAMBERT, C., TEPFER, D. Use of Agrobacterium rhizogenes to create transgenic apple trees having an altered organogenic response to hormones. Theoretical and Applied Genetics, v. 85, p. 105-109, 1992.

LAPIDOT, M.; GAFNEY, R.; DING, B.; WOLF, S.;LUCAS, J.; BEACHY, R. A dysfunctional movement protein of tobacco mosaic virus that partially modifies the plasmodesmata and limits virus spread in transgenic plants. The Plant Journal, v. 4, p. 959-970, 1993.

LEE, J.Y.; EDLUND, T.; NY, T.; FAYE, I.; BOMAN, H.G. Insect immunity. Isolation of cDNA clones corresponding to attacins and immune protein P4 from Hyalophora cecropia. EMBO Journal, v. 2, p.577-581, 1983.

LIN, C.H.; XIAO, L.; HOU, B.H. Optimization of electroporation conditions for expression of GUS activity in electroporated protoplasts and intact cells. Plant Physiology Biochemitry, v. 35, p. 959-968, 1997. 
LINDSEY, K. Genetic manipulation of crop plants. Journal of Biotechnology, v. 26, p. $1-28,1992$.

LIVINGSTONE, D.M.; BIRCH, R.G. Plant regeneration and microprojectilemediated gene transfer in embrionyc leaflets of pea-nut (Arachis hypogaea L). Australian Journal of Plant Phytopathology, v. 22, p. 585-591, 1995. MACHADO, M.L.C.; MACHADO, A.C.; HANZER, V.; WEISS, H.; REGNER, F.; STEINKELLNER, H.; MATTANOVICH, D.; PLAIL, R.; KNAPP, E.; KALTHOFF, B.; KATINGER, $H$. Regeneration of transgenic plants of Prunus armeniaca containing the coat protein gene of Plum Pox Virus. Plant Cell Reports, v.11, p.25-29, 1992.

MANDERS, G.; OTONI, W.C.; d'UTRA VAZ, F.B.; BLACKHALL, N.W.; POWER, J.B.; DAVEY, M.R. Transformation of passionfruit (Passiflora edulis $\mathrm{fV}$ flavicarpa Degener.) using Agrobacterium tumefaciens. Plant Cell Reports, v.13, p.697-702, 1994.

MANTE, S.; MORGENS, P.H.; SCORZA, R.; CORDTS, J.M.; CALLAHAM, A.M. Agrobacterium-mediated transformation of plum (Prunus domestica L.) hypocotyl slices and regeneration of transgenic plants. Bio/Technology, v.9, p.853-857, 1991.

MARBACH, P.A.S. História evolutiva das metaloproteases AAA. Piracicaba, 2004. 83p. Tese (Doutorado) - Escola Superior de Agricultura "Luiz de Queiroz", Universidade de São Paulo.

MAROTA, W.M.; OTONI, W.C.; CARNELOSSI, M.; SILVA, E.; AZEVEDO, A.A.; VIEIRA, G. Rhizogenes in in vitro shoot cultures of passion fruit (Passiflora edulis f. flavicarpa Deg.) is affected by ethylene precursor and by inhibitors. International Journal of Horticultural Science, v. 7, p. 47-54, 2001.

MATSUMOTO, T.K.; WEBB, D.T.; KUEHNLE, A.R. Hystology and origin of somatic embryos derived from Anthurium andraeanum Linden ex André Lamina. Journal of the Americam Society for Horticultural Science, v. 121, p. 404-407, 1996. 
MATTHYSSE, A.G.; MCMAHAN, S. Root colonization by Agrobacterium tumefaciens is reduced in cel, attB, attD, and attR mutants. Applied Environmental Microbiology, v. 64, p. 2341-2345, 1998.

MATTHYSSE, A.G.; YARNALL, H.; BOLES, S.B.; MCMAHAN, S. A region of the Agrobacterium tumefaciens chromosome containing genes required for virulence and attachment to host cells. Biochimica et Biophysics ActaGene Structure and Expression, v. 1490, p. 208-212, 2000.

McGARVEY, P.B.; KAPER, J.M. Transgenic plants for conferring virus tolerance: satellit aproach. In: KUNG, S. D.; WU, R. Transgenic Plants, New York : Academic Press. 1993. pp. 277-296.

MENZEL, C.M.; WINKS, C.W.; SIMPSON, D.R. Passionfruit in Queensland 1. prospects for commercial expansion. Queensland Agricultural Journal, v.114, p.13-18, 1988.

MIKI, B.; MCHUGH, S.. Selectable marker genes in transgenic plants: applications, alternatives and biosafity. Journal of Biotechnology, v. 107, p. 193-232, 2004.

MITRA, A.; ZHANG, Z. Expression fo human lactoferrin cDNA in tobacco cells produces antibacterial protein(s). Plant Physiology, v. 106, p. 977-981, 1994.

MITTLER, R.; SHULAEV, V.; LAM, E. Coordinated activation of programmed cell death and defense mechanisms in transgenic tobacco plants expressing a bacterial proton pump. Plant Cell, v. 7, p. 29-42, 1995.

MLYNAVORA, L.; KEIZER, L.; STIKEMA, W.J.; NAP. J.P. Approachlng the lower limits of transgene variability. Plant Cell, v. 8, p. 1589-1599, 1996.

MONTEIRO M.; APPEZZATO-DA-GLÓRIA B.; VALARINI M. J.; OLIVEIRA C.A.; VIEIRA M.L.C. Plant regeneration from protoplasts of alfafa (medicago sativa) via somatic embryogenesis. Scientia Agricola, v. 60, p. 683-689, 2003. 
MONTEIRO, A.C.B. de A.; NAKAZAWA, G.T.; MENDES, B.M.J.; RODRIGUEZ, A.P.M. Regneração in vitro de Passiflora suberosa a partir de discos foliares. Scientia Agricola, v.57, p.571-573, 2000a.

MONTEIRO, A.C.B.de A.; HIGASHI, E.N.; GONÇALVES, A.N.; RODRIGUEZ, A.P.M. A novel approach for the definition of the inorganic medium components for micropropagation of yellow passionfruit (Passiflora edulis Sims f. flavicarpa Deg.). In Vitro Cell Developmental Biology-Plant, v.36, p.527-531, 2000b.

MOORE, G.A.; JACOMO, C.C.; NEIDIGH, J.L.; LAWRENCE, S.D.; CLINE, K. Agrobacterium-mediated transformation Citrus stem segments and regeneration of transgenic plants. Plant Cell Reports, v. 11, p. 238-242, 1992.

MORAN ROBLES, J.M. Multiplication végétative in vitro des bourgeons axillaires de Passiflora edulis var. flavicarpa Degener et de P. molissima Bailey. Fruits, v.33, p.693-699, 1978.

MORAN ROBLES, J.M. Potentiel morphogénétique des entrenoeuds de Passiflora edulis var. flavicarpa Deg. et $P$. mollissima Bailey en culture in vitro. Turialba, v.29, p.224-228, 1979.

MOURAD-AGHA, N.; DEXHEIMER, J. Étude ultrastructurale de la différentiotion des éléments conducteurs dans une culture de tissue de Passiflora quadragularis L. I. Cals cultivés à l'obscurité. Cytologia, v.44, p.615-631, 1979.

MOURGUES, F.; BRISSET, M.N.; CHEVREAU, E. Strategies to improve plant resistance to bacterial disease through genetic engineering. Trends in Biotechnology, v.16, p.203-210, 1998.

MUKHOPADHYAY, A.; ARUMUGAM, N.; NANDAKUMAR, P.B.A.; PRADHAN, A.K.; GUPTA, V.; PENTAL, D. Agrobacterium-mediated genetic transformation of oilseed Brassica campestris: transformation frequency is strongly influenced by the mode of shoot regeneration. Plant Cell Reports, v. 11, p. 506-513, 1992. 
MULLINS, M.G.; TANG, F.C.A.; FACCIOTTI, D. Agrobacterium-mediated genetic transformation of grapevines: transgenic plants of Vitis rupestris Scheele and buds of Vitis vinifera L. Bio/Technology, v.8, p.1041-1045, 1990.

MURAKAMI, T.; ANZAI, H.; IMAI, S.; SATOH, A.; NAGAOKA, D.; THOMPSON, C.J. The bialaphos biosynthetic genes of Streptomyces hygroscopicus: molecular cloning and characterization of the gene cluster. Molecular and General Genetics, v.205, p.42-50, 1986.

MURASHIGE, T.; SKOOG, F. A revised medium for rapid growth and bioassays with tobacco tissue cultures. Physiologia Plantarum, v.15, p.473-497, 1962.

NAKAMURA, Y., KOBAYASHI, S., NAKAJIMA, I., Agrobacterium-mediated transformation and plant regeneration from hypocotyls segments of Japonese persimmon (Diospyrus kaki Thunb). Plant Cell Reports, v. 17, p. 435-440, 1998.

NEGROTTO, D.; JOLLEY, M.; BEER, S.; WENCK, A.R.; HANSEN, G. The use of phosphomannos-isomerase as a selectable marker to recover transgenic plants (Zea Mays L.) via Agrobacterium transformation. Plant Cell Repots, v. 19, p. 798-803, 2000.

NORELLI, J.; ALDWINCKLE, H. Increasing the fire blight resistance of apple by transformation with genes encoding antibacterial proteins. Acta Horticulturae, v.338, p.385-386, 1993.

NORELLI, J.L., ALDWINCKLE, H.S., DESTEFANO-BELTRAN, L., JAYNES, J.M.. Transgenic "Malling 26" apple expressing the attacin E gene has increased resistance to Erwinia amylovora. Euphytica, v.77, p.123-128, 1994.

NOVAES, Q.S.; REZENDE, J.A.M. Problemas no controle do endurecimento dos frutos do maracujazeiro utilizando estirpes fracas do Passion fruit woodiness virus (PWV). Fitopatologia Brasileira 26(supl.):519. 2001. 
OKADA, Y.; SAITO, A.; NISHIGUCHI, M.; KIMURA, T.; MORI, M.; HANADA, K.; SAKAI, J.; MIYAZAKI, C.; MATSUDA, Y.; MURATA, T. Virus resistance in transgenic sweetpotato [ipomoea batatas L. (Lam)] expressing the coat protein gene of sweet potato feathery mottle virus. Theoretical Applied Genetics, v. 103, p. 743-751, 2001.

OTAHOLA, V. Regeneración de plantas de parchita (Passiflora edulis f. flavicarpa) a partir del cultivo in vitro de discos de hojas. Bioagro, v.12, p.71-74, 2000.

OTONI, W.C. Hibridação e embriogênese somáticas e transformação genética em espécies de Passiflora. Viçosa, 1995. 198p. Tese (Doutorado) Universidade Federal de Viçosa.

OTONI, W.C., BLACKHALL, N., D'UTRAVAZ, F.B., CASALI, V.W.D., POWER, J.B., DAVEY, M.R. Somatic hybridization between Passiflora species, Passiflora edulis f. flavicarpa Deg. and $P$. incarnata. Journal of Experimental Botany, v.21, p.10 - 14, 1995a.

OTONI, W.C., CASALI, V.W.D., POWER, J.B., DAVEY, M.R. Isolamento de protoplastos de mesofilo de Passiflora suberosa L.: Influência da idade das plantas matrizes. Ceres, v. 43, p. 157 - 164, 1996b.

OTONI, W.C.; CASALI, V.W.D.; CECON, P.R.; DAVEY, M.R.; POWER, B.J. Regeneração de plantas de maracujazeiro (Passiflora coccinea Aubl.) a partir de protoplastos derivados de mesofilo. Revista Ceres, v. 42, p. 461468, $1995 b$.

OTONI, W.C.; CASALI, V.W.D.; POWER, J.B.; DAVEY, M.R. Expressão transitória do gene gus em maracujazeiro (Passiflora giberti N. E. Brown) mediada pelo bombardeamento de partículas. Revista Ceres, v.43, p.326335, 1996a.

PASSOS, I.R.S. Comportamento in vitro em Vitis spp e em Passiflora nitida H. B. K. Piracicaba, 1999, 112p. Tese (Doutorado). Escola Superior de Agricultura “Luiz de Queiroz - Universidade de São Paulo. 
PEÑA, L.; CERVERA, M.; JUÁREZ, J.; NAVARRO, A.; PINA, J.A.; DURÁNVILA, N.; NAVARRO, L. Agrobacterium-mediated transformation of sweet orange and regeneration of transgenic plants. Plant Cell Reports, v.14, p.616-619, 1995a.

PEÑA, L.; CERVERA, M.; JUÁREZ, J.; ORTEGA, C.; PINA, J.A.; DURÁN-VILA, N.; NAVARRO, L. High efficiency Agrobacterium-mediated transformation and regeneration of citrus. Plant Science, v.104, p.183-191, 1995b.

PÉREZ-MOLPHE-BALCH, E.; OCHOA-ALEJO, N. Regeneration of transgenic plants of Mexican lime from Agrobacterium rhizogenes-transformed tissues. Plant Cell Reports, v.17, p.591-596,1998

PERLAK, F.J.; DEATON, R.W.; ARMSTRONG, T.O.; FUCHS, R.L.; SIMS, S.R.; GREENPLATE, J.T.; FISCHOFF, D.A. Insect resistant cotton plants. Bio/Technology, v.8, p.939-943, 1990.

PIO-RIBEIRO, G.; MARIANO, R.L.R. Doenças do maracujazeiro (Passiflora spp). In: KIMATI, H.; AMORIM, L.; BERGAMIN FILHO, A.; CAMARGO, L.E.A.; REZENDE, J.A.M. (Ed.) Manual de Fitopatologia, 3. ed. São Paulo: Agronômica Ceres, 1997. vol 2, p.525-534.

POMPERMAYER, P. Identificação e caracterização de um promotor de canade-açúcar induzido por herbivoria. Piracicaba, 2004. 142p. Tese (Doutorado) - Escola Superior de Agricultura "Luiz de Queiroz", Universidade de São Paulo.

POWER, J.B.; CHAPMAN, J.V. Isolation, culture and genetic manipulation of plant protoplasts. In: Dixon, R. A. Plant Cell Culture: a practical approach, Washington: IRL Press; 1985, p. 37-66.

PUONTI-KAERLAS, J.; ERIKSSON, T.; ENGSTROM, P. Inheritance of a bacterial hygromycin phosphotransferase gene in the progeny of primary transgenic pea plants. Theoretical Applied Genetics, v. 84, p.443-450, 1992. 
QUECINI, V.M. Transferência direta de genes para plantas de Stylosanthes guianensis (Aubl.) Sw. Piracicaba, 1999. 172p. Tese (Doutorado) - Escola Superior de Agricultura "Luiz de Queiróz", Universidade de São Paulo.

QUECINI, V.M.; OLIVEIRA, C.A.; VIEIRA, M.L.C. Factors influencing electroporation-mediated gene transfer to Stylosanthes guianensis (Aubl.) Sw. Protoplasts. Genetic and Molecular Biology, v. 25, p. 73-80, 2002.

QUECINI, V.M.; VIEIRA, M.L.C. Plantas transgênicas. In: SERAFINI, L.A.; BARROS, N.M. de; AZEVEDO, J.L. de. (Coord.). Biotecnologia na agricultura e na agroindústria. Guaíba: Agropecuária, 2001. cap.8, p.279-331.

RADCHUK, V.V.; RYSCHKA, U.; SCHUMANN, G.; KLOCKE, E. Genetic transformation of cauliflower (Brassica oleracea var. botrytis) by direct DNA uptake into mesophyll protoplasts. Physiologia Plantarum, v. 114, p. 429-438, 2002.

RATHUS, C.; BIRCH, R.G. Electroporation for direct gene transfer into plant protoplasts. In: Murrai, D. R. Advanced Methods in Plant Breeding and Biotechnology, Austrália: C. A. B. International. 1991, p.74-102.

REIS, L.B. Dos Morfogênese in vitro de maracujá-amarelo (Passiflora edulis f. flavicarpa Degener) associada ao etileno e a agentes gelificantes. Viçosa, 2001. 89p. Dissertação (M.S.) - Universidade Federal de Viçosa.

REYNOIRD, J.P.; MOURGUES, F.; NORELLI, J.; ALDWINCKLE, H.S.; BRISSET, M.N.; CHEVREAU, E. First evidence for improved resistance to fire blight in transgenic pear expressing the attacin $E$ gene from Hyalophora cecropia. Plant Science, v.149, p.23-31, 1999.

REZENDE, J.A.M.; KITAJIMA, E. Viroses e fitoplasmose do maracujazeiro. (compact disc). In: SIMPÓSIO BRASILEIRO SOBRE A CULTURA DO MARACUJAZEIRO, 6., Campos dos Goytacazes, 2003. Resumo expandido. Campos dos Goytacazes: Cluster Informática, 2003. 
ROJO, E.; SHARMA, V.K.; KOVALEVA, V.; RAIKHE, N.V.L.; FLETCHER, J.C. CLV3 Is Localized to the Extracellular Space, Where It Activates the Arabidopsis CLAVATA Stem Cell Signaling Pathway. Plant Cell, v. 14, p. 969-977, 2002.

ROMANO, E.; MONTE, D.C. Plantas transgênicas resistentes a vírus. In: TORRES, A.C.; CALDAS, L.S.; BUSO, J.A. (Eds.). Cultura de Tecidos e Transformação Genética de Plantas. Brasília: EMBRAPA. 1999. p.783814.

ROSS, A.H; MANNERS, J.M.; BIRCH, R.G. Embryonic callus production, plant regeneration, and transient gene expression following particle bombardment in the pasture grass Cenchrus ciliarus (Gramineae). Australian Journal of Botany, v. 43, p. 193-199, 1995.

ROSSIN, R.P.; CASTRO, A.P.; OLIVEIRA, E.J.; PÁDUA, J.G.; VIEIRA, M.L.C. Análise preliminar da diversidade genética de xanthomonas axonopodis pv. passiflorae e da agressividade em populações comerciais de maracujá-amarelo (passiflora edulis sims f. flavicarpa deg.). (compact disc) In: CONGRESSO NACIONAL DE GENÉTICA, 50., Florianópolis 2004, Resumos. Florianópolis: SBG, 2004.

RUGGIERO, C. Situação da cultura do maracujazeiro. Informe Agropecuário, v. 21, p. 5-9, 2000.

RUGINI, E. MARIOTTI, D., PELLEGRINESHI, A., MENCUCCINI, M. Increase of rooting ability in the wood species kiwi (Actinidia deliciosa A. Chev.) by transformation with Agrobacterium rhizigenes rol gene. Plant Cell Reports, v. 10, p. 291-295, 1991.

RUSHTON, P.J.; REINSTADLER, A.; LIPKA, V.; LIPPOK, B.; SOMSSICH, I.E. Synthetic plant promoters containing defined regulatory elements provide novel insights into pathogen- and wound-induced signaling. Plant Cell, v. 214, p. 749-762, 2002. 
SÁGI, L.; REMY, S.; VERELST, B.; PANIS, B.; CAMMUE, B.P.A.; VOLCKAERT, G.; SWENNEN, R. Transient gene expression in transformed banana (Musa cv. Bluggoe) protoplasts and embryogenic cell suspensions. Euphytica, v.85, p.89-95, 1995.

SAMBROOK, J.; FRITSCH, E.F.; MANIATIS, T. Molecular Cloning: A Laboratory Manual. New York: Cold Spring Harbour Laboratory Press, 2001. 3v.

SANGER, F.; AIR, G.M.;. BARRELL, B.G.; BROWN, N.L.; COULSON, A.R.; FIDDES, J.C.; HUTCHISON, C.A.; SLOCOMBE, P.M.; SMITH, M. Nucleotide sequence of bacteriophage phi X174 DNA. Nature, v.165, p. 687-695, 1977.

SANTOS FILHO, H.P.; LARANJEIRA, F.F.; SANTOS, C.C.F.; BARBOSA, C.J. Doenças do maracujazeiro. In.LIMA, A.A.; CUNHA, M.A.P. Maracujá: produção e qualidade na passicultura. Cruz das Almas: Embrapa Mandioca e Fruticultura, 2004. 366p.

SARMA, K.S.; EVANS, N.E.; SELBY, C. Effect of carbenicillin and cefotaxime on somatic embryogenesis of Sitka spruce (Picea sitchensis (Bong.) Carr.). Journal of Experimental Botany, v. 46, p. 1779-1781, 1995.

SAWAHEL, W.A. Transgenic plants: performance, release and containment. World Journal of Microbiology and Biotechnology, v. 10, p. 139-144, 1994.

SHENG, J.; CITOVISKY, V. Agrobacterium-plant cell DNA transport: Have virulence proteins, will travels. Plant Cell, v. 8, p. 1699-1710, 1996.

SILVA, M.B. Transformação genética de maracujá-amarelo (Passiflora edulis f. flavicarpa Degener) mediada por Agrobacterium tumefaciens. Viçosa, 1998. 45p. Dissertação (Mestrado) - Universidade Federal de Viçosa. 
SILVA-FILHO, M.C. One tickit for multiple destinations: dual targeting of proteins to distinct subcellular locations. Current opinion in Plant Biology, v. 6, p. 589-595, 2003.

SILVA-FILHO, M.C.; FALCO, M.C. Plantas transgênicas no melhoramento. In: NASS, L.L.; VALOIS, A.C.C.; MELO, I.S. de; VALADARES-INGLIS, M.C. Recursos genéticos e melhoramento. Rondonópolis: Fundação MT, 2001. p.1011-1056.

SINISTERRA, X.H.; POLSTON, J.E.; ABOUZID, A.M.; HIEBERT, E. Tobacco plants transformed with a modified coat protein of Tomato Mottle Begomovirus show resistance to virus infection. Virology, v. 89, p. 701706, 1999.

SMIGOCKI, A.C.; HAMMERSCHLAG, F.A. Regeneration of plants from peach embryo cells infected with a shooty mutant strain of Agrobacterium. Journal of the American Society for Horticultural Science, v.116, p.1092-1097, 1991.

SMITH, F.D.; JOFRE-GARFIAS, A.; SANFORD, J.C. Transformation of bean apical dome cells by microparticle bombardment. Phytopathology, v.82, p.1167-1168, 1992.

SOMERS, D.A.; MAKAREVITCH, I. Transgene integration in plants: poking or patching holes in promiscuous genomes? Current Opinion in Biotechnology, v. 15, p. 126-131, 2004.

SOUZA JÚNIOR, M.T.; VENTUROLI M.F.; COELHO M.C.F.; RECH FILHO E.L. Análise de sistemas gene marcador/ agente seletivo alternativos para seleção positiva de embriões somáticos transgênicos de mamoeiro. Revista Brasileira de Fisiologia Vegetal, v. 13, p. 365-372, 2001.

SOUZA, J.S.I.; MELETTI, L.M.M. Maracujá. Espécies, variedades, cultivo. Piracicaba: FEALQ, 1997. 179p. 
STENGER, D.C. Strain-Specific Mobilization and AmpLification of a Transgenic Defective-Interfering DNA of the Geminivirus Beet Curly Top Virus. Virology, v. 203, p. 397-402,1994

STEWART, C.N.; ADANG, M.J.; ALL, J.N.; RAYMER, P.L.; RAMACHANDRAM, S.; PARROTT, W.A. Insect control and dosage effects in transgenic canola containing a synthetic Bacillus thuringiensis crylAc gene. Plant Physiology, v.112, p.115-120, 1996.

STRITTMATTER, G.; JANSSENS, J.; OPSOMER, C.; BOTTERMAN, J. Inhibition of fungal disease development in plants by engineering controlled cell death. Bio/Technology, v. 13, p. 1085-1088, 1995.

TADA, Y.; SAKAMOTO, M.; FUJIMURA, T. Efficient gene introduction into rice by electroporation and analysis of transgenic plants: use of electroporation buffer lacking chloride ions. Theoretical and Applied Genetics, v.80, p. 475-480, 1990.

TAKAHASHI, E.K. Transferência do gene atacinaA para plantas de maracujá amarelo (Passiflora edulis Sims. f. flavicarpa Deg.) por biobalística. Piracicaba, 2002. 137p. Tese (Doutorado) - Escola Superior de Agricultura “Luiz de Queiroz", Universidade de São Paulo.

TAKAHASHI, E.K.; FALCO, M.C.; VIEIRA, L. G.; PEREIRA, L.F.P.; VIEIRA, M.L.C. Sistema de transformação e micropropagação de Passiflora edulis Sims. f. flavicarpa Deg. (compact disc) In: CONGRESSO NACIONAL DE GENÉTICA, 47., Águas de Lindóia. 2001. Resumo, Águas de Lindóia: SBG, 2001.

TEIXEIRA, C.G. Cultura. In: TEIXEIRA, C.G.; CASTRO, J.V.; TOCCHINI, R.P.; NISIDA, A.L.A.C.; HASHIZUME, T.; MEDINA, J.C.; TURATTI, J.M.; LEITE, R.S.S.F.; BLISKA, F.M.M.; GARCIA, A.E.B. Maracujá: cultura, matéria prima, processamento e aspectos econômicos. Campinas: ITAL, 1994. $142 p$.

TINLAND, B. The integration of T-DNA into the plant genomes. Trends in Plant Science, v. 1, p. 178-184, 1996. 
TZFIRA T, LI J, LACROIX B, CITOVSKY V. Agrobacterium T-DNA integration: molecules and models. TRENDS in Genetics, v. 20, p. 375-383, 2004

TZFIRA, T.; CITOVSKY, V. From host recognition to T-DNA integration: the function of bacterial and plant genes in the Agrobacterium-plant cell interaction. Molecular Plant Pathology, v. 1, p. 201-212, 2000.

URWIN, P. E., ATKINSON, H. J., WALLER, D. A., McPhERSON, M. J. Engineered oryzacystatin-I expressed in transgenic hairy roots confers resistance to Globera pallida. Plant Journal, v. 8, p. 121-131, 1995.

VANDERPLANK, J. Passion flowers. Cambridge Press, 1996. 224p.

VASIL, I.K.; THORPE, T.A. Plant Cell and Tissue Culture. London: Kluwer Academic Publishers, 1994. 312p.

VIEIRA, M.L.C. Hibridação somática em plantas. BIOtecnologia Ciência e Desenvolvimento, v.3, p.36-40, 1997.

VIEIRA, M.L.C.; APPEZZATO-DA-GLÓRIA, B. Aplicações das técnicas de cultura de tecidos no melhoramento de plantas. NASS, L.L.; VALOIS, A.C.C.; MELO, I.S. de; VALADARES-INGLIS, M.C. Recursos Genéticos e Melhoramento. Rondonópolis: Fundação MT, 2001. p.911-938.

VIEIRA, M.L.C.; DORNELAS, M.C. Regeneration of plants from protoplasts os Passiflora Species (Passion fruit).. In: BAJAJ, Y.P.S. Biotechnology in Agriculture and Forestry. Berlin: Springer, 1996, p. 108-119.

WALBOT, V. Gene pulser electroprotocols, Hercules: Bio-Rad Laboratories, 1993. 882p.

WANG, A.S.; EVANS, R.A.; ALTENDORF, P.R.; HANTEN, J.A.; DOYLE, M.C.; POSICHAN, J.L. A mannose selection system for production of fertile transgenic maize plants from protoplase. Plant Cell Reports, v. 19, p. 654-660, 2000. 
WANG, G.L.; SONG, W.Y.; RUAN, D.L.; SIDERIS, S.; RONALD, P.C. The cloned gene, Xa21, confers resistance to multiple Xanthomonas oryzae pv. oryzae isolates in transgenic plants Molecular Plant- Microbe Interaction, v. 9, p. 850-855, 1996.

WEGENER, C.; BARTLING, S.; OLSEN, O.; WEBER, J.; VON WETTSTEIN, D. Pectatelyase in transgenic potatoes confers pre-activation of defence against Erwinia carotovora. Physiological and Molecular Plant Pathology, v. 49, p. 359-376, 1996.

WILLIANS, S.; FRIEDRICH, L.; DINCHER, S.; CAROZZI, N.; KESSMAN, E.; RYALS, J. Chemical regulation of Bacillus thuringiensis delta endo-toxin expression in transgenic plants. Bio/Technology, v. 7, p. 194-200, 1993.

WILMINK, A.; DONS, J.J.M. Selective agents and marker genes for use in transformation of monocotyledonous plants. Plant Molecular Biology Report, v.11, p.165-185, 1993.

WRIGHT, M.; DAWSON, J.; DUNDER, E.; SUTTIE, J.; REED, J.; KRAMER, C.; CHANG, Y.; NOVITZKY, R.; WANG, H.; ARTIM-MOORE, L. Efficient biolistic transformation of maize (Zea mays L.) and wheat (Triticum aestivum L.) using the phosphomannose isomerase gene, pmi, as the selectable marker. Plant Cell Reports, v.20, p.429-436, 2001.

YANG, Z.N.; INGELBRECHT, I.L.; LOUZADA, E.; SKARIA, M.; MIRKOV, T.E. Agrobacterium-mediated transformation of the commercially important grapefruit cultivar Rio Red (Citrus paradisi Macf.). Plant Cell Reports, v.19, p.1203-1211, 2000.

YANISCH-PERRON, C.; VIEIRA, J.; MESSING, J. Improved MI3 phage cloning vectors and host strains: nucleotide sequences of the M13mp18 and pUC19 vectors. Gene, v. 33, p. 103-119, 1985. 
YU, C.; HUANG, S.; CHEN, C.; DENG, A.; LING, P.; GMITTER, F.G. Factors affeting Agrobacterium-mediated transformation and regeneration of sweet orange and citrange. Plant Cell, Tissue and Organ Culture, v. 71, p. 147-155, 2002. 
Palavras-Chave - 1. Agrobacterium 2. Bacteriose vegetal 3. Maracujá 4.

Proteína de planta 5. Transformação genética 6. Xanthomonas

Key word - 1. Agrobacterium 2. Plant disease 3. Passion fruit 4. Plant protein

5. Genetic transformation 